\title{
Performance and Stability of Large Planar Solid Oxide Fuel Cells Using Phosphine Contaminated Hydrogen Fuel
}

Timothy B. A. Ross

Follow this and additional works at: https://researchrepository.wvu.edu/etd

\section{Recommended Citation}

Ross, Timothy B. A., "Performance and Stability of Large Planar Solid Oxide Fuel Cells Using Phosphine Contaminated Hydrogen Fuel" (2015). Graduate Theses, Dissertations, and Problem Reports. 6532. https://researchrepository.wvu.edu/etd/6532

This Thesis is protected by copyright and/or related rights. It has been brought to you by the The Research Repository @ WVU with permission from the rights-holder(s). You are free to use this Thesis in any way that is permitted by the copyright and related rights legislation that applies to your use. For other uses you must obtain permission from the rights-holder(s) directly, unless additional rights are indicated by a Creative Commons license in the record and/ or on the work itself. This Thesis has been accepted for inclusion in WVU Graduate Theses, Dissertations, and Problem Reports collection by an authorized administrator of The Research Repository @ WVU. For more information, please contact researchrepository@mail.wvu.edu. 


\title{
Performance and Stability of Large Planar
}

\section{Solid Oxide Fuel Cells Using Phosphine Contaminated}

\section{Hydrogen Fuel}

\author{
Timothy B. A. Ross
}

Thesis submitted to the Benjamin M. Statler College of Engineering and Mineral Resources

at West Virginia University

in partial fulfillment of the requirements for the degree of

Master of Science

In

Chemical Engineering

John W. Zondlo, Ph.D., Chair

Edward M. Sabolsky, Ph.D.

Charter D. Stinespring, Ph.D.

Department of Chemical Engineering

Morgantown, WV 2015

Keywords: solid oxide fuel cell, SOFC, phosphine

Copyright 2015 Timothy B. A. Ross 


\begin{abstract}
Performance and Stability of Large Planar Solid Oxide Fuel Cells Using Phosphine Contaminated Hydrogen Fuel
\end{abstract}

Timothy B. A. Ross

The objective of this work was to investigate how fuel utilization and method of fuel delivery for a large planar fuel cell with co-flow configuration will affect the degradation rate and mechanism of phosphine poisoning of a solid-oxide fuel cell (SOFC). Coal syngas, a potential fuel source for SOFCs, contains gas phase impurities such as $\mathrm{PH}_{3}$, which rapidly degrade Ni-based SOFC anodes. Researchers have shown significant reconstruction of Ni-anodes in button cell configurations with $\sim 0.5 \mathrm{mV} \mathrm{hr}^{-1}$ degradation rates, but it is not evident that these rates will occur in actual stack applications. A singular planar stack repeat unit was constructed using a Haynes 242 interconnect manifold with a cobalt-oxide coating. The cell was operated at $800^{\circ} \mathrm{C}$ with $10 \mathrm{ppm} \mathrm{PH}_{3}$ in dry $\mathrm{H}_{2}$. Cell performance was evaluated over 500 hours by means of voltage-current measurements and impedance spectroscopy. $\mathrm{PH}_{3}$ was measured entering the fuel cell and then exiting the fuel cell in the exhaust. The post-run material analysis of the contaminated cell was conducted via x-ray diffraction (XRD), $x$-ray photoelectron spectroscopy (XPS), and scanning electron micrographs (SEM). In this work, there was no appreciable degradation attributable to $\mathrm{PH}_{3}$ poisoning of the anode. No reconstruction of the Ni-anode was observed. This result is in contrast to the many papers published on the subject, where anode-supported SOFC in a button cell configuration degraded rapidly. It is believed that the increased fuel utilization of the large planar cell compared to the published literature using button cells contributed to increased $\mathrm{H}_{2} \mathrm{O}$ generation which led to side reactions that prevented the phosphorus from interacting with the $\mathrm{Ni}$-anode; platinum components may have catalyzed these reactions. 


\section{Acknowledgements}

I would first like to thank my research advisor, Dr. John Zondlo. Without his support, I would not have pursued my Master's degree in Chemical Engineering. Dr. Zondlo's and Dr. Edward Sabolsky's guidance during this project has been invaluable. I need to thank Dr. Ismail Celik for is support in funding this research and Hayri Sezar for his contributions. I would also like to thank Mr. Jim Hall for his help maintaining the manifolds and general lab troubleshooting. Thanks to Ms. Kathy Sabolsky for her help with materials. Thanks to the SRF staff for training and assisting me with the various pieces of analytical equipment l've needed. I also appreciate the work of those who came before me on this project.

This work is conducted under US DOE (Department of Energy) EPSCoR Program. It is jointly sponsored by US DOE Office of Basic Energy Sciences, NETL (National Energy Technology Laboratory), WV State EPSCoR Office and the West Virginia University under grant number DE-FG02-06ER46299. Dr. Tim Fitzsimmons is the DOE Technical Monitor. Dr. R. Bajura is the Administrative Manager and Dr. I. Celik is the Technical Manager and Principal Investigator of this project.

I would also like to thank my friends and family who have kept me motivated and sane while attaining my degrees. I want to specifically recognize my mom (Angela), my dad (Bryan), sister (Tiffany), and brother (Trenten). Without them, none of this would have been possible. Of my dear friends, there are too many to name, but I have been able to keep life in perspective thanks to you all. On to the next adventure... 


\section{Contents}

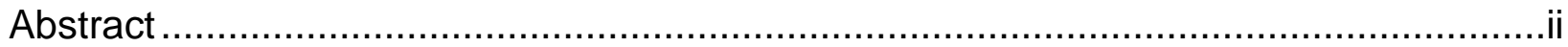

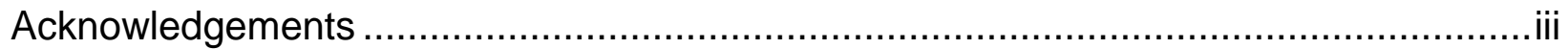

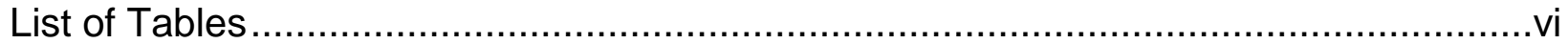

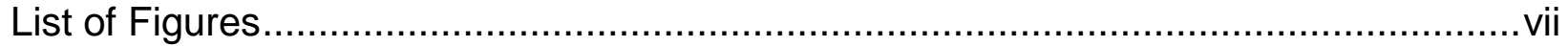

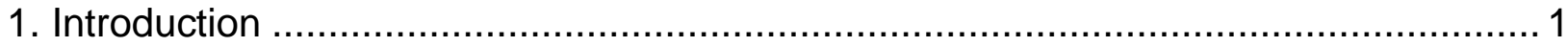

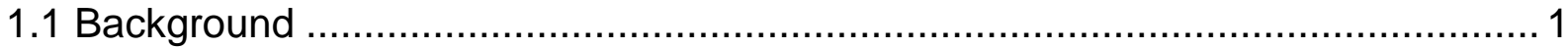

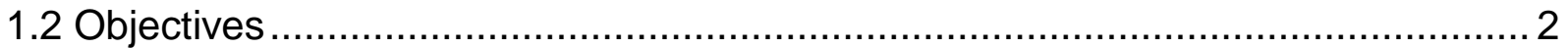

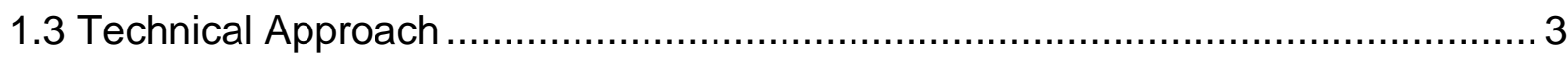

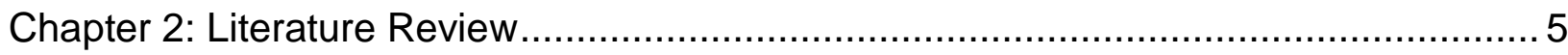

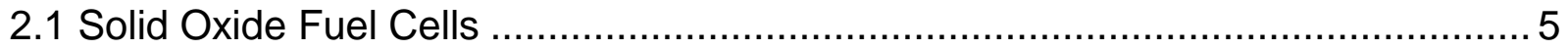

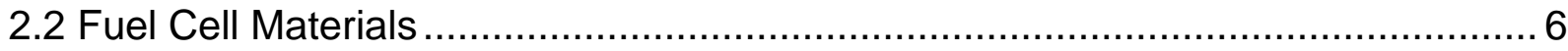

2.3 Sources of Potential Impurities in Fuel Gas ................................................ 8

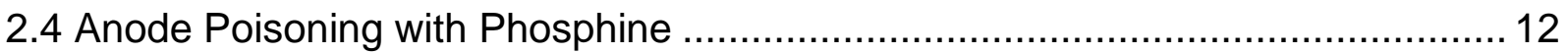

2.5 Impurity Modeling of Fuel Cells................................................................ 17

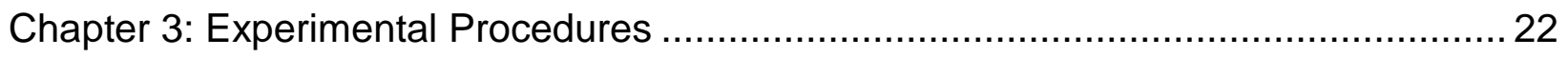

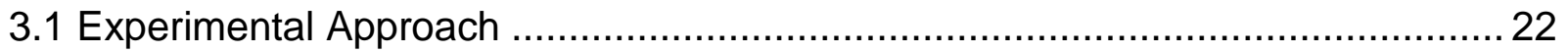

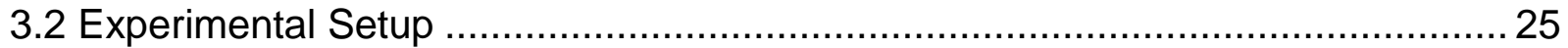

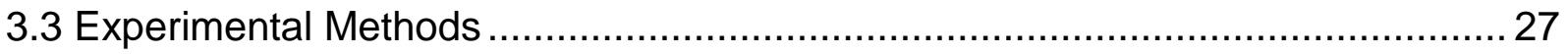

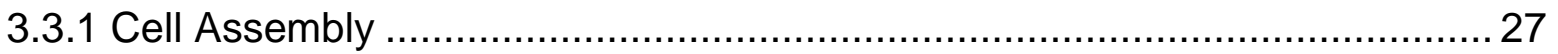

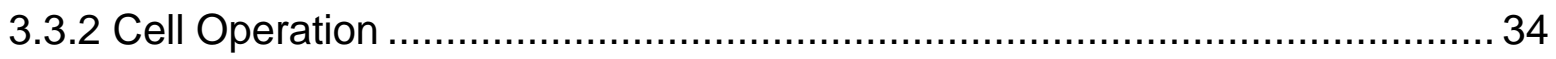

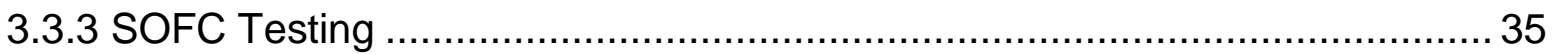

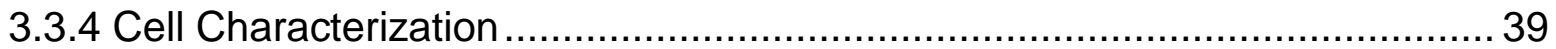




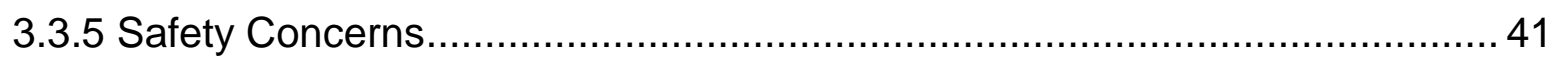

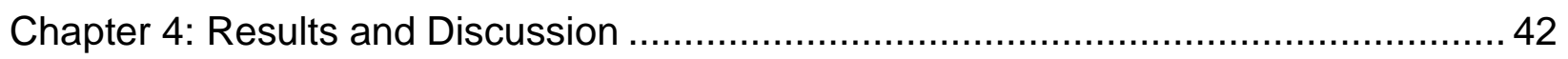

4.1 SOFC Operation with Hydrogen ................................................................ 42

4.2 SOFC Operation in Phosphine - Preliminary Trial......................................... 49

4.3 SOFC Operation in Phosphine - Second Trial .............................................. 53

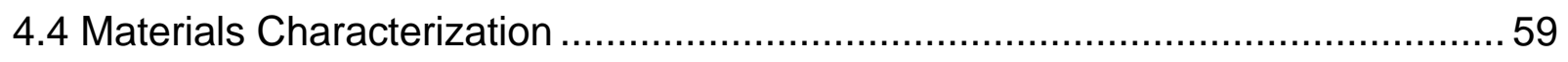

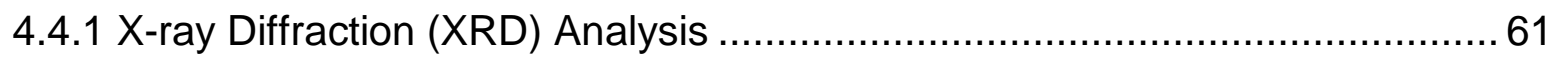

4.4.2 X-ray Photoelectron Spectroscopy (XPS) Analysis ....................................67 67

4.4.3 Scanning Electron Microscopy (SEM) Analysis....................................... 73

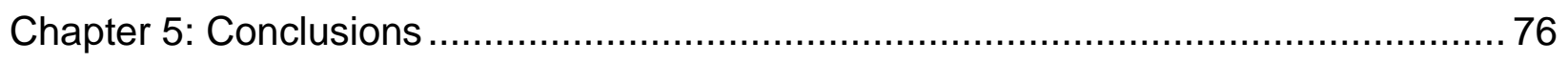

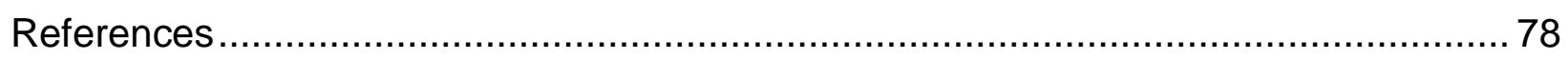




\section{List of Tables}

Table 2.1: Typical Compositions of the product synthesis gas from various gasifiers and

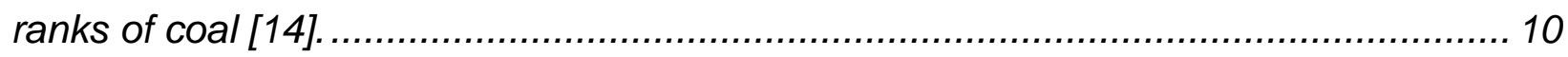

Table 2.2: Possible Contaminants from a Gasification Process [30]........................... 11

Table 2.3 DREAM SOFC planar solid oxide fuel cell parameters [39]. ........................ 19 


\section{List of Figures}

Figure 2.1 Operating principle of a SOFC showing reactions occurring at the anode (oxidation) and cathode (reduction) [3]

Figure 2.2 Cell voltage versus time under load $0.5 \mathrm{~A} \mathrm{~cm}^{-2}$ operating on syngas before and after adding 10ppm $\mathrm{PH}_{3}$ at $800^{\circ} \mathrm{C}[32]$ 12

Figure 2.3 (a) clean reduced anode (b) $\mathrm{PH}_{3}$ poisoned (c) SEM micrograph of the surface of the clean reduced anode (d) SEM micrograph of $\mathrm{PH}_{3}$ poisoned anode [32]. 13 Figure 2.4 Anode supported cell voltage versus time under load of $0.25 \mathrm{~A} / \mathrm{cm}^{2}$ for cells operated for 117 hours at $800^{\circ} \mathrm{C}$ [33]

Figure 2.5 (a) TEM image indicating $\mathrm{YPO}_{4}$ precipitate formation in $\mathrm{PH}_{3}$ contaminated syngas (b) spectra indicating composition (c) selected area diffraction pattern [33] .... 15 Figure 2.6 Electrolyte-supported cell resistance increases an order of magnitude faster than the anode-supported cell at $800^{\circ} \mathrm{C}$ over various concentrations, adapted from [35.]

Figure 2.7 Ni/YSZ coupon after exposure to synthetic coal gas containing $0.5 \mathrm{ppm}$ phosphine flowed lengthwise across the coupon at a rate of $3.4 \mathrm{~cm}^{3}$ gas per $\mathrm{cm}^{2}$ of cross-sectional area per second $\left(\mathrm{cm}^{3} \mathrm{gas} / \mathrm{cm}^{2} / \mathrm{sec}\right)$ for $75 \mathrm{~h}[\mathrm{G} 10]$...... 17

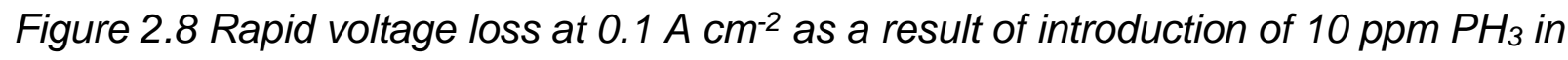
$\mathrm{H}_{2}[39]$. 20

Figure 2.9 Contours of $\mathrm{H}_{2}$ mass fraction at anode/electrolyte interface at different $\mathrm{PH}_{3}$ exposure times [39].

Figure 3.1 Typical button cell testing stand. The small button cells are sandwiched between flanges that allow flow of the gases directly at the cell face [40]. 
Figure 3.2 Planar repeat cell stack for large scale power generation [42]. Each unit cell (anode, electrolyte, and cathode), with sealing materials and interconnects, are repeated until the desired power output it achieved [41].

Figure 3.3 Diagram of fuel cell test stand shows the gas distribution system, furnace for heating the SOFC, and the external load circuit. 26

Figure 3.4 Circuit diagram with boost power supply installed in series with the SOFC and load cell.

Figure 3.3 Left is the LSM/LSM-GDC cathode and right is the NiO-GDC/NiO-YSZ anode of the NEXTCELL ${ }^{\mathrm{TM}}-7$ produced by NexTech Materials, Ltd. 28 Figure 3.4 Haynes ${ }^{\circledR} 242$ alloy manifold with Co electrodeposition. The Co is the area inside of the dashed box. Co is only deposited where the active area of the cell contacts the manifold. Arrows indicate gas flow direction. 29

Figure 3.5 Mica schematics for use in cutting the mica gaskets with the laser cutter. The gasket on the left (without the slot) contacts the manifold. The sheet on the right contacts the fuel cell and has a slot for the voltage tap to pass through. 30 Figure 3.6 (a) Manifold with Co electrodeposition (b) Pt paste on tops of ridges. This helps ensure electrical conductivity between the cell and the manifolds (c) Pt mesh on top of ridges with Pt voltage tap in "J" shape extending out left side. There is a slit on the second (or top) mica gasket to allow the voltage tap to extend to the outside of the furnace. (d) Fuel cell placed on top of cathode (e) Layer of Pt paste applied over top of fuel cell to ensure electrical conductivity between all components (f) Completed assembly with both manifolds sandwiching the fuel cell to be inserted into the furnace. 
Figure 3.7 Load cell securely connected to end of manifold using wire nuts and clamps.

Figure 3.8 Manifold assembly loaded into the furnace with fuel lines connected. The weights used to apply pressure onto the stack, heating tape, and voltage measuring leads are also visible.

Figure 3.9 A typical voltage/current (V/I) curve of a fuel cell showing cell behavior and polarization losses [48].

Figure 3.10 Typical representation of impedance spectroscopy using a Nyquist plot [48].

Figure 3.11 Typical bode plot representation. Y-axis can also be real impedance (Z') or imaginary impedance (Z').

Figure 3.12 Specific positions of sample locations taken from each SOFC after testing.

Figure 4.1 Standard baseline performance of cells operated in hydrogen gas operated at a current density of $100 \mathrm{~mA} \mathrm{~cm}^{-2}$. Degradation rates were calculated to the order of microvolts and considered negligible.

Figure 4.2 Cell performance before (75 hours) and well after (505 hours) burn-in has been completed. Arrows point towards the respective axis for each set of curves.

Figure 4.3 Nyquist plots for cells at OCV. The left intercept occurs at $3000 \mathrm{~Hz}$ and the

right intercept would be below $4 \mathrm{~Hz}$.

Figure 4.4 Nyquist plots for cells loaded at 1.0 A. The left intercept occurs at $4000 \mathrm{~Hz}$ and the right intercept would be near $0.1 \mathrm{~Hz}$. 
Figure 4.5 Nyquist plots at OCV, $0.5 \mathrm{~A}$, and $1.0 \mathrm{~A}$ for $\mathrm{H} 14$ cell after 505 hours of operation

Figure 4.6 Bode plot for baseline $\mathrm{H}_{2}$ cell at OCV (no bias current). Resistances decrease as the anode reduction is completed after the burn-in period. 48 Figure 4.7: Cell voltage over time at $100 \mathrm{~mA} \mathrm{~cm}^{-2}$ with $10 \mathrm{ppm}$ phosphine in $\mathrm{H}_{2}$ (voltages after Hour 93 are corrected due to one of the voltage taps breaking). Degradation rate was $0.026 \mathrm{mV} \cdot h^{-1}$ 50

Figure 4.8 Hour 25 was the second hour of phosphine exposure. Hour 116 was the first measurement from the new measuring point on the manifold. Hour 472 was the last measurement with phosphine. Hour 496 was pure hydrogen.

Figure 4.9: Nyquist plot of impedance spectrum before and after exposure to $10 \mathrm{ppm}$ $\mathrm{PH}_{3}$, until voltage/current taps broke. 52 Figure 4.10 Cell voltage over time at $100 \mathrm{~mA} \mathrm{~cm}^{-2}$ with $10 \mathrm{ppm}$ phosphine. Degradation rate after introduction of $\mathrm{PH}_{3}$ is $3 \times 10^{-6} \mathrm{~V} \mathrm{hr}^{-1}$. 54

Figure 4.11 $\mathrm{PH}_{3}$ concentration measurements measured at the sampling port before the inlet of the anode manifold and again at the exhaust of the anode manifold. 55

Figure 4.12 "PH3 - 0 Hour" is the measurement taken initially when the $\mathrm{PH}_{3}$ contaminated fuel was introduced. The curves do not shift downward. "50 Hours after PH3" is the measurement taken after the cell had been allowed to run for 50 hours after $\mathrm{PH}_{3}$ exposure. 56 Figure 4.13 The peak power density was $170 \mathrm{~mW} \mathrm{~cm}^{-2}$ after the 187 hour burn-in period. There was a $6.2 \%$ decrease after introduction of $\mathrm{PH}_{3}$ contaminated fuel, but this stabilized over the rest of the test. 57 
Figure 4.14 Impedance spectra at OCV. The left intercept occurs at $4000 \mathrm{~Hz}$ and the

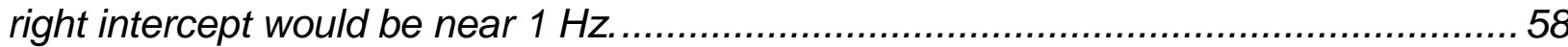

Figure 4.15 Bode plot showing minimal changes over 170 hours of operation. Curves would be shift up if any of the resistances were significantly increasing. 59 Figure 4.16 Images of cell and manifolds after running for $500+$ hours in pure $\mathrm{H}_{2}$ (left) and 10 ppm of $\mathrm{PH}_{3}$ in $\mathrm{H}_{2}$ (right). There are no differences observable to $\mathrm{PH}_{3}$ poisoning. There is slightly more oxidation on the edges of the $\mathrm{H}_{2}$ cell manifold attributable to a less than ideal seal by the mica gaskets. 60

Figure 3.12 Specific positions of sample locations to be taken from each planar SOFC after testing.

Figure 4.17 Overlay of XRD spectra for SOFC anode exposed to $10 \mathrm{ppm} \mathrm{PH}_{3}$ in $\mathrm{H}_{2}$. No peaks corresponding to any Ni-P phases are observable. Spectra are nearly identical to

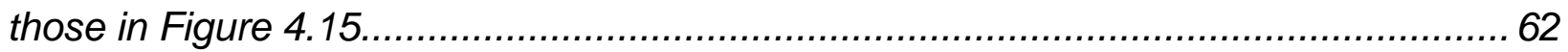
Figure 4.18 Overlay of XRD spectra for SOFC using pure $\mathrm{H}_{2}$ fuel. ...........................63 Figure 4.19 XRD spectra from button cell $\mathrm{PH}_{3}$ experiment. Ni-P phases are clustered

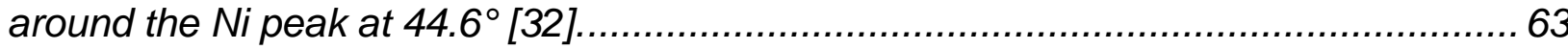
Figure 4.20 Platinum layer near the center of the anode showed no residual phosphorus compounds. 66 Figure 4.21 XPS spectra comparing location $P 1$ of baseline $\mathrm{H}_{2}$ anode to location $\mathrm{P} 1$ of anode exposed to $10 \mathrm{ppm} \mathrm{PH}_{3}$. 68 Figure 4.22 There is no evidence of phosphorus on the surface of the sample at location P1. Phosphorus $2 p 3 / 2$ binding energy peak should occur at $130.2 \mathrm{eV}$ and there is no peak in this range. 68 
Figure 4.23 XPS spectra comparing location $\mathrm{P} 2$ of baseline $\mathrm{H}_{2}$ anode to location $\mathrm{P} 2$ of anode exposed to $10 \mathrm{ppm}^{\mathrm{PH}_{3}}$ 69

Figure 4.24 There is no evidence of phosphorus on the surface of the sample at location P2. Phosphorus $2 p$ 3/2 binding energy peak should occur at $130.2 \mathrm{eV}$ and there is no peak in this range. 70

Figure 4.25 XPS spectra comparing location P5 of baseline $\mathrm{H}_{2}$ anode to location P5 of

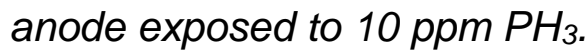
71

Figure 4.26 There is no evidence of phosphorus on the surface of the sample at location P5. Phosphorus $2 p 3 / 2$ binding energy peak should occur at $130.2 \mathrm{eV}$ and there is no peak in this range.

Figure 4.27 Platinum layer from anode shows no residual phosphorus. 72 Figure 4.28 (a) Clean reduced anode surface SEM micrograph at location P1 of baseline $\mathrm{H}_{2}$ sample and (b) fuel cell exposed to $10 \mathrm{ppm} \mathrm{PH}_{3}$ for 450 hours. The pore structure is intact and there is no Ni-P formation on the surface.

Figure 4.29 (a) Clean reduced anode surface SEM micrograph at location P2 of baseline $\mathrm{H}_{2}$ sample and (b) fuel cell exposed to $10 \mathrm{ppm} \mathrm{PH}_{3}$ for 450 hours. The pore structure is intact and there is no Ni-P formation on the surface.

Figure 4.30 Cross sectional SEM micrograph at location P5 of anode exposed to 10 ppm $\mathrm{PH}_{3}$. There is no evidence of phosphorus penetration into the anode. Dense electrolyte is on the left with the anode extending to the right. 75 Figure 4.31 Cross sectional SEM micrograph at the center of the anode of the baseline $\mathrm{H}_{2}$ fuel cell. Dense electrolyte is on the right with anode extending to the left. 75 


\section{Introduction}

\subsection{Background}

Fuel cells are an emerging alternative energy source that are more efficient and generate less emissions per unit power than traditional fossil fuel sources due to their high energy density [1]. Depending on the specific design of the system, this efficiency can be as high as $85 \%$ [2]. Solid oxide fuel cells are of specific interest due to their high efficiency, long-term stability, fuel flexibility, and low emissions [3]. Advances in materials have contributed to increased efficiency and decreased cost of fuel cells [4].

Fuel cells are being used in applications such as backup power generators, distributed power generation, transportation, and even cell-phone chargers $[5,6]$. Battery technology has been lagging behind the ability to generate usable electricity [7]. Fuel cells can be used as a means of on-demand local power generation to combat this problem [6]. Large companies such as IKEA are even getting involved; at its Emeryville, California location, a biogas powered fuel cell system was installed in the summer of 2015 to pair with the store's existing solar power system [8].

Large, fixed traditional fossil fuel power generation systems are becoming less popular in favor of clean, distributed power generation systems, such as home solar systems, fuel cell units, and wind turbines [9]. In 2013, the world added 143 gigawatts of renewable energy compared to 141 gigawatts from plants that burn fossil fuels [10]. A 2014 General Electric report suggests that by 2020, \$206 billion will be invested annually in distributed power installations [11]. The recent agreement by The United States and China to reduce net greenhouse gas emissions 26-28 percent below 2005 
levels by 2025 shows the commitment by the world's two largest energy consumers to develop cleaner, more efficient technologies [12]. As the demand for energy across the world increases, fossil fuels will not be able to power the globe alone. A diversified energy portfolio will be required to meet these increased needs. Fuel cells will undoubtedly be an important part of this diversified portfolio due to their high efficiency, fuel flexibility, and reduced environmental impact [13].

\subsection{Objectives}

The purpose of this work was to investigate the performance of large area, planar solid oxide fuel cells (SOFC) and the degradation rate for phosphine poisoning of a nickel-based anode. System variables were the fuel utilization and fuel delivery as seen in a co-flow configuration in a planar fuel cell stack. This initially consisted of establishing a methodology for cell construction. These initial cells were operated with pure hydrogen $\left(\mathrm{H}_{2}\right)$ gas to evaluate the baseline degradation trends. All testing was performed with commercially available Ni/YSZ anode, electrolyte-supported, planar fuel cells.

The long range goals were to have a representative fuel cell that runs for approximately 500 hours using pure $\mathrm{H}_{2}$ as the fuel, at least two trials with $\mathrm{H}_{2}$ contaminated with $10 \mathrm{ppm}$ of phosphine $\left(\mathrm{PH}_{3}\right)$. In addition, a variety of techniques such as $\mathrm{x}$-ray diffraction (XRD), $\mathrm{x}$-ray photoelectron spectroscopy (XPS), and scanning electron microscopy (SEM) were used to characterize the surface of the fuel cell anode before and after testing. 
The specific objectives of this work were:

1. Establish a methodology for construction of the test stand. Strict adherence to the assembly procedure reduced variation in the data collected due to factors such as electrical connectivity.

2. Initial fuel cells were operated with pure hydrogen gas as the fuel to establish baseline operating conditions and performance.

3. Polarization curves and electrochemical impedance spectroscopy (EIS) data were collected at regular intervals and in the same order throughout the duration of the test.

4. Testing was performed with commercially available large $(10 \mathrm{~cm} \times 10 \mathrm{~cm})$, planar, electrolyte-supported fuel cells.

5. There were two trials using $\mathrm{H}_{2}$ with $10 \mathrm{ppm} \mathrm{PH}_{3}$. This was done to verify the results and determine the rate of degradation of the cell's performance.

6. Utilized XRD, XPS, and SEM to characterize the surface of the fuel cell anode before and after testing.

\subsection{Technical Approach}

This project started with the design of the fuel cell stand and the fabrication of the manifolds to be used for testing large $(10 \mathrm{~cm} \times 10 \mathrm{~cm})$ planar SOFC. The manifolds were designed to be similar to planar repeat stacks at the industrial scale. The test stand is composed of the furnace that houses the manifolds, the piping system to 
deliver the gases to the fuel-cell manifolds, and the electrical and computer equipment to monitor the performance of the cell.

The cell assembly procedure was established. This methodology was used to assemble each subsequent cell. Baseline testing was conducted to establish the typical performance of the cells. This baseline testing employed pure, dry $\mathrm{H}_{2}$ as the anode fuel gas. Once this baseline has been established, it was extended to compare the effects of feeding $10 \mathrm{ppm} \mathrm{PH}_{3}$ in $\mathrm{H}_{2}$ to the anode.

Additionally, the procedure for the material characterization of the fuel cells was established. This includes the use of the PANalytical X'Pert Pro X-ray Diffractometer (XRD), the Physical Electronics PHI 5000 VersaProbe X-Ray Photoelectron Spectroscopy (XPS), and the Hitachi S-4700F Scanning Electron Microscope (SEM) provided by the Shared Research Facilities (SRF) of WVU. Training for use of the equipment was provided by the SRF staff, but the procedure for the preparation of the samples required development. Upon shutdown of the system, it was desired to limit the exposure of the fuel cell to the environment until it can be fully analyzed.

The data from the phosphine runs was compared to the baseline hydrogen tests. These included monitoring cell voltage over time at a constant current load and/or fuel utilization, voltage-current measurements, impedance spectroscopy, and all of the material characterization data. 


\section{Chapter 2: Literature Review}

In this chapter, an overview is provided on published literature and research relevant to solid oxide fuel cells. The first section covers the basic principles and operation of SOFC. The second section examines SOFC materials. The third section investigates sources of impurities in the fuel gas. The fourth section investigates SOFC poisoning with phosphine. The final section discusses SOFC computer modeling.

\subsection{Solid Oxide Fuel Cells}

Solid oxide fuel cells (SOFCs) are electrochemical devices that operate at high temperatures $\left(500-1000^{\circ} \mathrm{C}\right)$ to generate electricity by oxidizing a fuel source. There are three basic components to an SOFC: cathode, electrolyte, and anode. Air is fed to the cathode, where oxygen molecules are reduced to oxygen anions $\left(\mathrm{O}^{2-}\right)$. A dense electrolyte layer separates the cathode and anode and conducts the oxygen ions via ionic diffusion. The fuel, primarily hydrogen, is fed to the anode, where it is oxidized [14]. As shown in Figure 2.1, the major reactions that occur at each electrode (cathode and anode) are simplified as:

Cathode reaction:

$$
O_{2}+4 e^{-} \rightarrow 20^{2-}
$$

Anode reaction:

$$
\begin{gathered}
2 \mathrm{H}_{2}+2 \mathrm{O}^{2-} \rightarrow 2 \mathrm{H}_{2} \mathrm{O}+4 e^{-} \\
2 \mathrm{H}_{2}+\mathrm{O}_{2} \rightarrow 2 \mathrm{H}_{2} \mathrm{O}
\end{gathered}
$$

The hydrogen acts as the fuel and the source of electrons which are conducted through an external load circuit and back to the cathode to reduce the oxygen molecules in the air. These oxygen ions are then able to pass through the dense electrolyte by ionic diffusion. When they reach the anode, these oxygen ions react with 
the hydrogen to produce water vapor and more electrons. The cathode and anode both need to be porous to allow the diffusion of gases to the electrolyte layer, where the reactions take place. This reaction zone is referred to as the triple-phase boundary and is discussed in the next section.

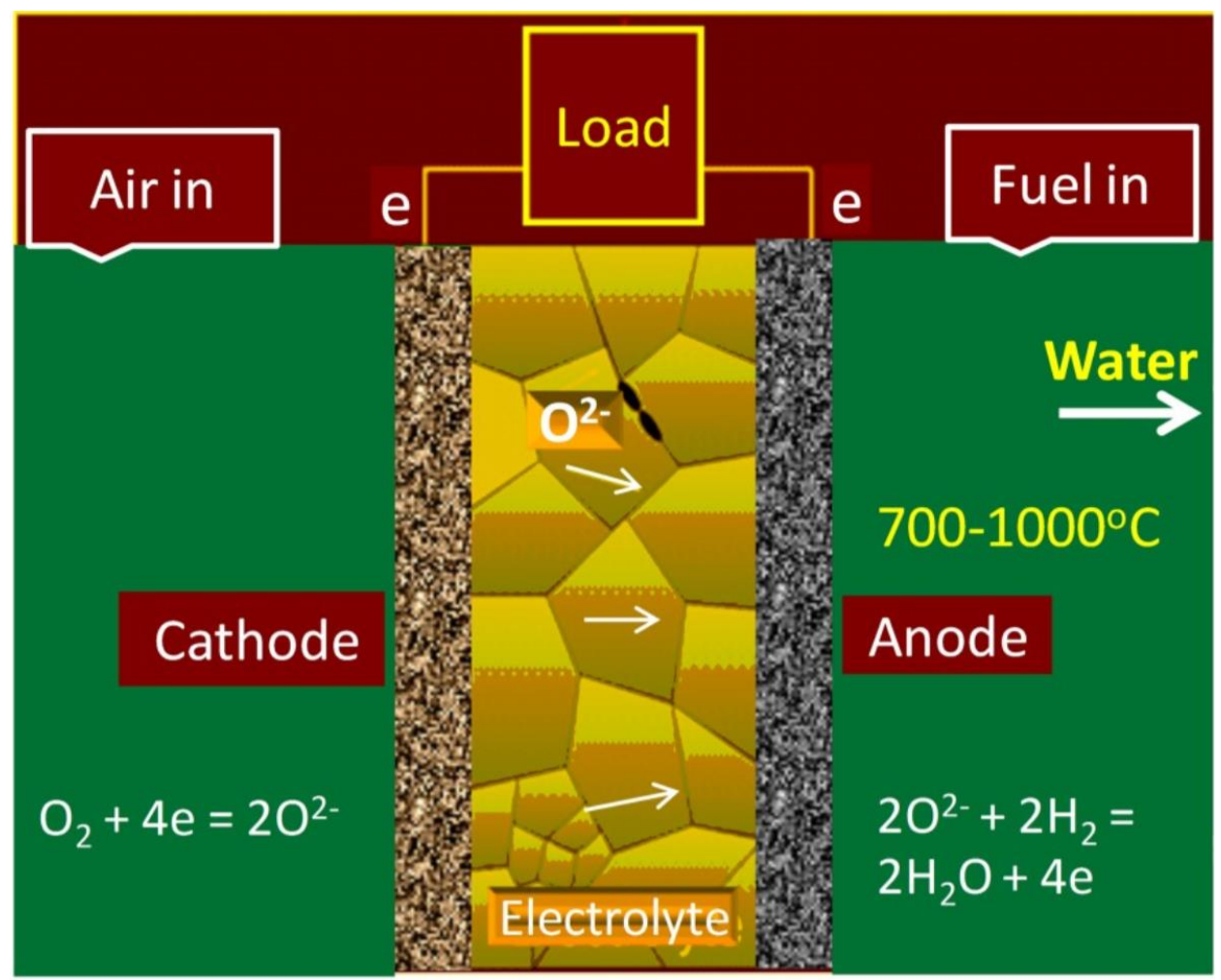

Figure 2.1 Operating principle of a SOFC showing reactions occurring at the anode (oxidation) and cathode (reduction) [3].

\subsection{Fuel Cell Materials}

There are a number of considerations for selecting the materials of the electrolyte, cathode, and anode: electrochemical behavior, thermal expansion, stability, and oxygen ionic and electronic transport properties. Matching these component properties is the most challenging aspect of designing solid oxide fuel cells [15]. 
These properties are relevant at the triple phase boundaries (TPB) where the electrolyte, electrode, and gas interact. At the cathode-electrolyte interface, oxygen disassociates and is reduced to oxygen ions that are conducted across the electrolyte. At the electrolyte-anode interface, the fuel is electrochemically oxidized with the oxygen ions [16]. Composite electrodes incorporate materials similar to the electrolyte layer which allows for better mechanical property matching (such as thermal expansion coefficients) and improved reaction kinetics [15].

Nickel is the primary anode electrode material due to its high electrical conductivity and catalytic activity in the fuel-oxidation reaction. It is typically blended with yttria-stabilized zirconia (YSZ) to form a cermet. This is done to match the thermal expansion properties of the chosen electrolyte and because $\mathrm{Ni}$ is a poor ionic conductor. Adding YSZ also allows the reaction zone to extend further into the anode from the TPB, due to its ionic conduction properties [17].

The key requirements of the dense electrolyte (that separates the cathode and anode) are that it is a good ionic conductor to minimize the cell resistance, has negligible electronic conductivity to minimize leakage currents, and is stable in both oxidizing and reducing environments [18], [19]. Zirconia-based $\left(\mathrm{ZrO}_{2}\right)$ ceramics are wellestablished as an electrolyte material [20]. YSZ is the most commonly used as yttriastabilized zirconia, but scandia-stabilized zirconia (ScSZ) is a viable alternative as well.

Nomura et al. [21] found the ionic conductivity of 8ScSZ to be higher than $8 Y S Z$, at 0.32 and $0.16 \mathrm{~S} / \mathrm{cm}$, respectively. A higher ionic conductivity in the electrolyte allows for similar performance at lower operating temperatures. Additionally, it has been found that there is a maximum dopant concentration for each material, where performance 
declines after this maximum. The highest conductivity levels in $\mathrm{Zr}_{1-\chi} \mathrm{Y}_{x} \mathrm{O}_{2-x / 2}$ and $\mathrm{Zr}_{1-x} \mathrm{Sc}_{x} \mathrm{O}_{2-x / 2}$ ceramics are observed at $x=0.08-0.11$ and $0.09-0.11$, respectively [20].

For cathode electrodes, perovskite-type manganites are used due to their high electronic conductivity, electrocatalytic activity towards oxygen reduction, and moderate thermal expansion coefficients that are compatible with the common electrolyte material YSZ. Specifically, strontium doped lanthanum manganite (LSM) is the material of choice [15]. Similar to the Ni anode, LSM is a poor ionic conductor and is usually paired with a good ionic conductor to facilitate the cathode reactions [22]. YSZ can again be used, but other materials such as gadolinium doped ceria (GDC) are possible as well.

GDC is a better ionic conductor than YSZ and can be employed in both the cathode and anode. In the anode, a GDC interlayer can be employed between the dense electrolyte and the typical Ni-YSZ cermet to improve the anode reaction kinetics and ionic conductivity [19]. In the cathode, GDC can also be used instead of YSZ to increase the ionic conductivity, with the added benefit of being unreactive with LSM [23].

\subsection{Sources of Potential Impurities in Fuel Gas}

A common fuel gas is synthesis gas (syngas), which is a mixture of $\mathrm{H}_{2}, \mathrm{CO}$, and $\mathrm{CO}_{2}$. Syngas is generated via the reformation of a hydrocarbon feedstock, such as methane, coal, or biomass. This reforming, or gasification, process takes place at high temperature and pressure in the presence of steam and carefully controlled amounts of air or oxygen [24]. 
Methane reformation via steam is the most common route for hydrogen production and it accounts for $95 \%$ of the hydrogen made in the United States. [25] The primary reactions are the steam reforming reaction and the water-gas shift reaction [26]:

Steam reforming

$$
\begin{gathered}
\mathrm{CH}_{4}+\mathrm{H}_{2} \mathrm{O} \leftrightarrow \mathrm{CO}+3 \mathrm{H}_{2} \\
\mathrm{CO}+\mathrm{H}_{2} \mathrm{O} \leftrightarrow \mathrm{CO}_{2}+\mathrm{H}_{2}
\end{gathered}
$$

Water gas shift

These reactions occur at high temperatures $\left(700-1000^{\circ} \mathrm{C}\right)$ and high pressure (325 bar). Excess steam is fed to these reactors in the presence of a catalyst to drive the water-gas shift reaction towards hydrogen production.

Coal is another important feedstock of syngas. The gasification of coal is a twostep process. First, pyrolysis eliminates compounds of low molecular weight at temperatures between $300-500^{\circ} \mathrm{C}$; these are typically tars and non-condensable gases. The rate of the pyrolysis step is influenced by the specific composition and properties of the coal [27], [28]. The next step is the char gasification. There is a large list of possible reactions, however the main reactions are [28]:

$$
\begin{gathered}
\mathrm{C}+\mathrm{CO}_{2} \rightarrow 2 \mathrm{CO}+3 \mathrm{H}_{2} \\
\mathrm{C}+\mathrm{H}_{2} \mathrm{O} \rightarrow \mathrm{CO}+\mathrm{H}_{2} \\
\mathrm{C}+\mathrm{O}_{2} \rightarrow \mathrm{CO}_{2}+\mathrm{H}_{2} \\
\mathrm{CO}+\mathrm{H}_{2} \mathrm{O} \leftrightarrow \mathrm{CO}_{2}+\mathrm{H}_{2} \\
\mathrm{C}+\mathrm{H}_{2} \rightarrow \mathrm{CO}+\mathrm{CH}_{4}
\end{gathered}
$$

The composition of the syngas depends on the feedstock to produce the syngas. For syngas derived from coal, Table 2.1 [14] shows that the gas composition can vary 
widely depending on the type of gasifier and the rank of coal used to produce that syngas.

Table 2.1: Typical Compositions of the product synthesis gas from various gasifiers and ranks of coal [14].

\begin{tabular}{|l|c|c|c|c|c|c|}
\hline Gasifier type & Moving-bed & Fluidized-bed & \multicolumn{4}{|c|}{ Entrained-bed } \\
\hline Manufacturer & Lurgi & Winkler & \multicolumn{1}{c|}{$\begin{array}{c}\text { Destec } \\
\text { Toppers- } \\
\text { Totzek }\end{array}$} & $\begin{array}{l}\text { Texaco } \\
\text { Shell }\end{array}$ \\
\hline Coal & Illinois no. 6 & Texas lignite & $\begin{array}{l}\text { Appalachian } \\
\text { Bit. }\end{array}$ & $\begin{array}{l}\text { Illinois } \\
\text { no. } 6\end{array}$ & $\begin{array}{l}\text { Illinois } \\
\text { no. } 6\end{array}$ & $\begin{array}{l}\text { Illinois } \\
\text { no. } 6\end{array}$ \\
\hline Mole percent & & & & & & \\
\hline $\mathrm{Ar}$ & Trace & 0.7 & 0.8 & 0.9 & 0.9 & 1.1 \\
\hline $\mathrm{CH}_{4}$ & 3.3 & 4.6 & 0.6 & - & 0.1 & - \\
\hline $\mathrm{C}_{2} \mathrm{H}_{4}$ & 0.1 & - & - & - & - & - \\
\hline $\mathrm{C}_{2} \mathrm{H}_{6}$ & 0.2 & - & - & - & - & - \\
\hline $\mathrm{CO}$ & 5.8 & 33.1 & 45.2 & 43.8 & 39.6 & 63.1 \\
\hline $\mathrm{CO}$ & 11.8 & 15.5 & 8 & 4.6 & 10.8 & 1.5 \\
\hline $\mathrm{COS}$ & Trace & - & - & 0.1 & - & 0.1 \\
\hline $\mathrm{H}_{2}$ & 16.1 & 28.3 & 33.9 & 21.1 & 30.3 & 26.7 \\
\hline $\mathrm{H}_{2} \mathrm{O}$ & 61.8 & 16.8 & 9.8 & 27.5 & 16.5 & 2 \\
\hline $\mathrm{H}_{2} \mathrm{~S}$ & 0.5 & 0.2 & 0.9 & 1.1 & 1 & 1.3 \\
\hline $\mathrm{N}_{2}$ & 0.1 & 0.6 & 0.6 & 0.9 & 0.7 & 4.1 \\
\hline $\mathrm{NH}_{3}+\mathrm{HCN}$ & 0.3 & 0.1 & 0.2 & - & - & - \\
\hline
\end{tabular}

For fuel cell applications, the potential impurities in coal derived syngas are of utmost importance. These impurities can react with the anode of the fuel cell and cause irreversible damage that eventually destroys the fuel cell. Trace amounts of nearly all naturally occurring elements are possible [29], [30]. Absorption, adsorption, membrane diffusion, and filtration are all methods that have been employed to treat the gas before it reaches the fuel cell. Table 2.2 lists the trace-level contaminants and their concentration in the Kingsport gasification stream and an estimate from University of North Dakota Energy and Environmental Research Center [30]. 
Table 2.2: Possible Contaminants from a Gasification Process [30].

\begin{tabular}{|l|c|c|}
\hline Contaminant & $\begin{array}{c}\text { Concentration at the } \\
\text { Kingsport facility (ppmv) }\end{array}$ & $\begin{array}{c}\text { UND-EERC } \\
\text { estimate }\end{array}$ \\
\hline Arsine $\left(\mathrm{AsH}_{3}\right)$ & $0.15-0.58$ & 0.2 \\
\hline Thiophene & & 1.6 \\
\hline Chlorine $(\mathrm{Cl})$ & & 120 \\
\hline Methyl Fluoride $\left(\mathrm{CH}_{3} \mathrm{~F}\right)$ & 2.6 & \\
\hline Methyl Chloride $\left(\mathrm{CH}_{3} \mathrm{Cl}\right)$ & 2.01 & \\
\hline Hydrogen Chloride $(\mathrm{HCl})$ & $<1$ & \\
\hline $\mathrm{Fe}(\mathrm{CO})_{5}$ & $0.05-5.6$ & \\
\hline $\mathrm{Ni}(\mathrm{CO})_{5}$ & $0.001-0.025$ & \\
\hline $\mathrm{CH}_{3} \mathrm{SCN}$ & 2.1 & 0.07 \\
\hline Phosphine $\left(\mathrm{PH} \mathrm{H}_{3}\right)$ & 1.9 & 0.01 \\
\hline Antimony $(\mathrm{Sb})$ & 0.025 & 6 \\
\hline Cadmium $(\mathrm{Cd})$ & & 0.002 \\
\hline Chromium $(\mathrm{Cr})$ & $<0.025$ & 0.17 \\
\hline Mercury $(\mathrm{Hg})$ & $<0.025$ & \\
\hline Selenium $(\mathrm{Se})$ & $<0.15$ & \\
\hline Vanadium $(\mathrm{V})$ & $<0.025$ & \\
\hline Lead $(\mathrm{Pb})$ & & \\
\hline Zinc $(\mathrm{Zn})$ & 9 & \\
\hline
\end{tabular}

Even at trace-levels (0-10 ppm), these contaminants can have severely detrimental effects on the fuel cell. It is important to investigate the potential effects of these contaminants in the event of failure of the gas clean-up system.

The focus of this work is to investigate the specific effect of phosphorus on the fuel cell anode via the use of phosphine $\left(\mathrm{PH}_{3}\right)$ gas. Other trace impurities, such as hydrogen sulfide $\left(\mathrm{H}_{2} \mathrm{~S}\right)$, have already been well studied [31]. The chemical and microstructural changes of phosphorus poisoning are not well understood and require further study. 


\subsection{Anode Poisoning with Phosphine}

There are multiple recent publications that have discussed the effect of phosphine. Xu et al. [32] exposed a commercially available, Ni/YSZ anode-supported ( $0.9 \mathrm{~mm}$ thick) fuel cell to $10 \mathrm{ppm}$ of phosphine mixed with syngas. This work showed that the $\mathrm{PH}_{3}$ caused a significant loss of performance and an irreversible structural modification of the Ni-YSZ in the central part of the anode that was directly exposed to the flow of the fuel gas. The degradation rate in Figure 2.2 was found to be $0.46 \mathrm{mV} / \mathrm{h}$ with the cell at constant load of $0.5 \mathrm{~A} \mathrm{~cm}^{-2}$ at $800^{\circ} \mathrm{C}$

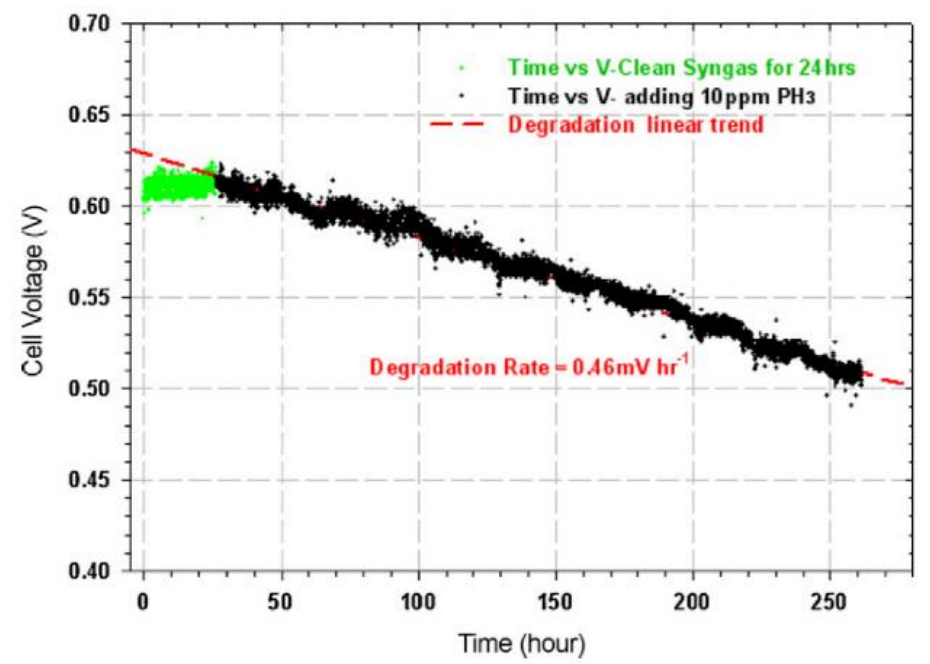

Figure 2.2 Cell voltage versus time under load $0.5 \mathrm{~A} \mathrm{~cm}^{-2}$ operating on syngas before and after adding $10 \mathrm{ppm} \mathrm{PH}_{3}$ at $800^{\circ} \mathrm{C}$ [32]

XRD spectra showed $\mathrm{Nis}_{2} \mathrm{P}_{2}$ as the dominant nickel phase via the reaction in Eq.

2.11 .

$$
2 \mathrm{PH}_{3}(g)+4 \mathrm{Ni} \rightarrow 2 \mathrm{Ni}_{2} \mathrm{P}_{5}(\mathrm{~s})+3 \mathrm{H}_{2}(g)
$$

This reaction was found to be instantaneous and irreversible. Figure 2.3 contrasts the images of a clean reduced anode and a cell poisoned with $10 \mathrm{ppm}$ of $\mathrm{PH}_{3}$ [32]. From 
(b), the $10 \mathrm{ppm}$ of $\mathrm{PH}_{3}$ in $\mathrm{H}_{2}$ leaves an iridescent sheen on the surface of the anode, and (d) shows the clear loss of the pore structure and agglomeration of material on the surface when compared to (c)
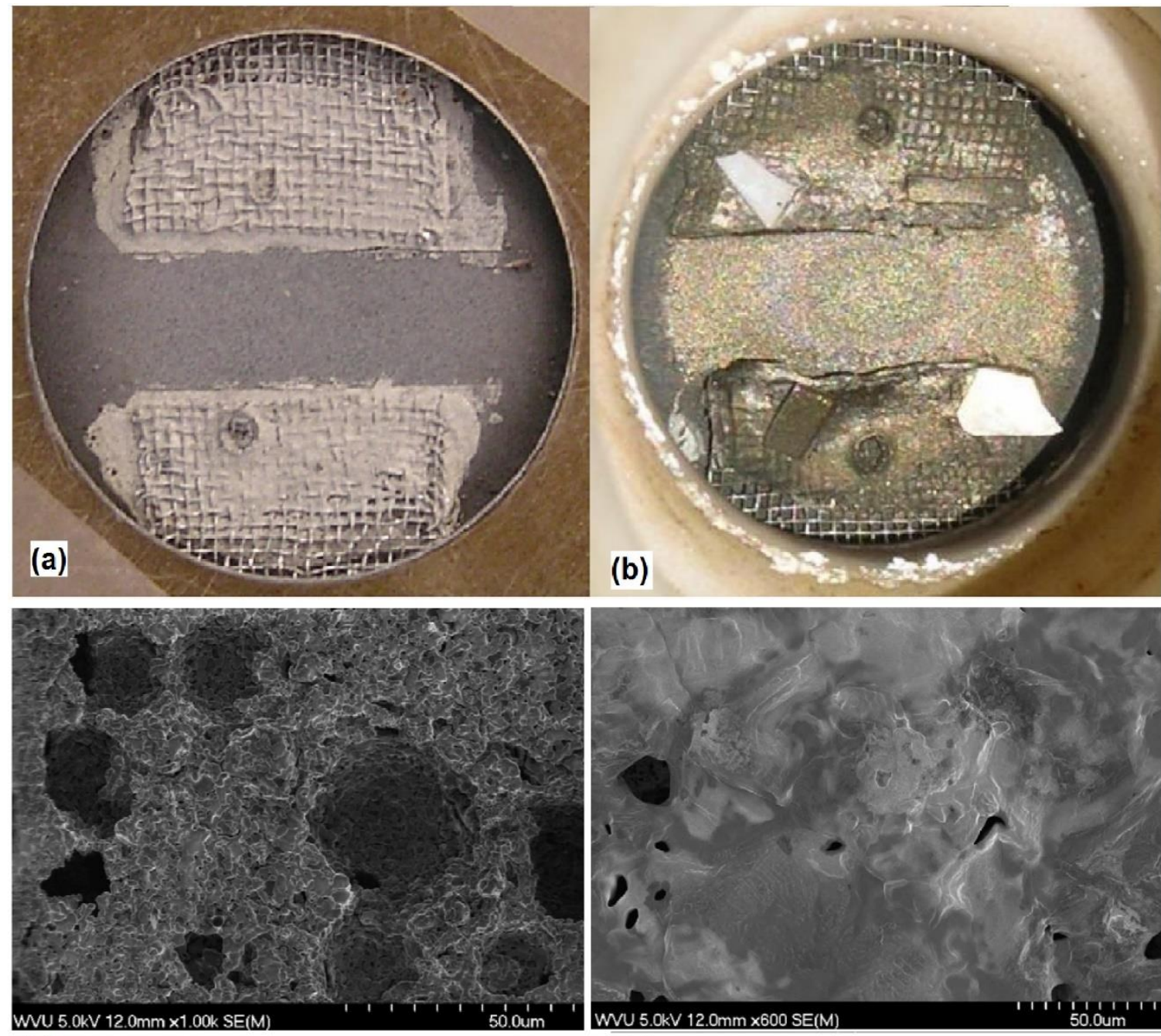

(c)

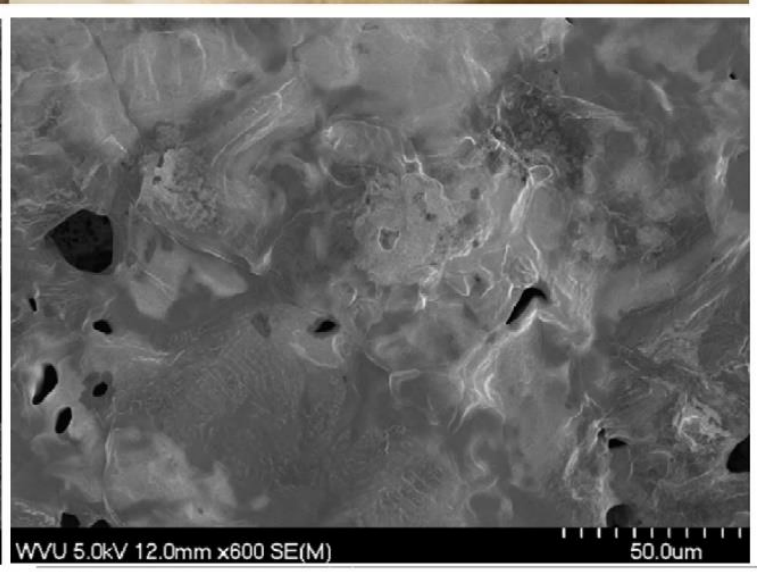

(d)

Figure 2.3 (a) clean reduced anode (b) $\mathrm{PH}_{3}$ poisoned (c) SEM micrograph of the surface of the clean reduced anode (d) SEM micrograph of $\mathrm{PH}_{3}$ poisoned anode [32].

Chen et al. [33] examined the effect of phosphine present in syngas or hydrogen fuel with the yttria component of the anode. Again, a commercially available, Ni/YSZ anode-supported ( $\sim 0.9 \mathrm{~mm}$ thick) similar to Xu et al., fuel cell was used. Loaded at 0.25 
$\mathrm{A} / \mathrm{cm}^{2}$, the degradation rate of $\mathrm{PH}_{3}$ contained in syngas was $0.7 \mathrm{mV} / \mathrm{h}$, which was greater than the rate for the $\mathrm{PH}_{3}$ in hydrogen alone, $0.0099 \mathrm{mV} / \mathrm{h}$, as shown in Figure 2.4 .

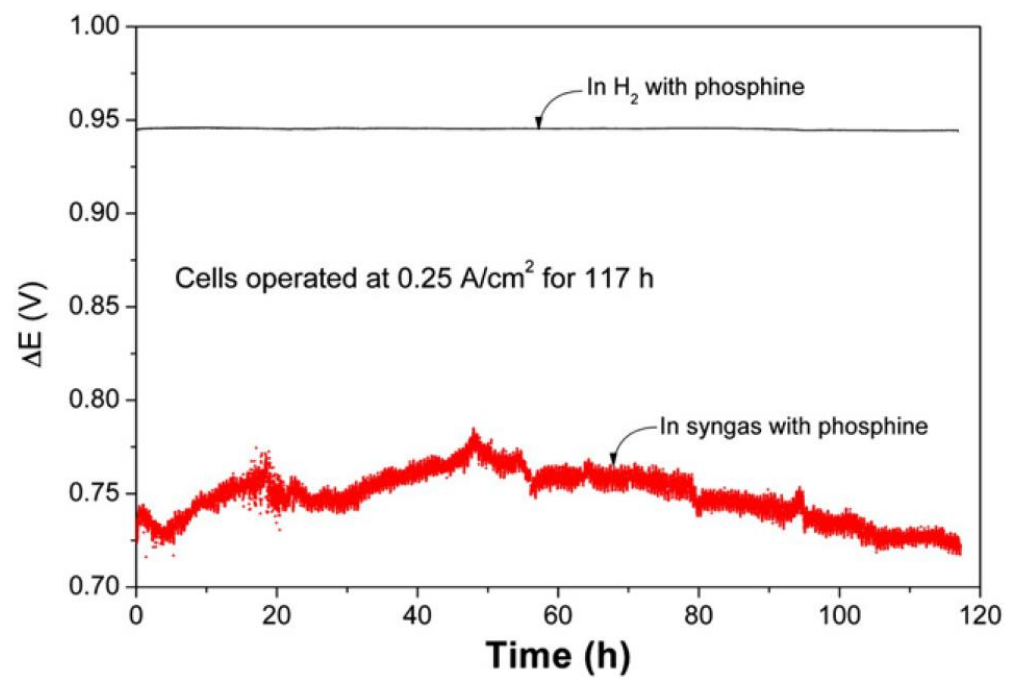

Figure 2.4 Anode supported cell voltage versus time under load of 0.25 $A / \mathrm{cm}^{2}$ for cells operated for 117 hours at $800^{\circ} \mathrm{C}$ [33]

Extensive analysis via electron microscopy showed that there was significant rearrangement of the pore structure in the poisoned anode, and it also indicated that the Ni-P reaction zone consists of $\mathrm{Nix}_{x} \mathrm{P}_{y}$ phases, primarily $\mathrm{Ni}_{5} \mathrm{P}_{2}$, as in $\mathrm{Xu}$ et al. [32].

Additionally, Chen et al. [33] observed a previously unidentified $\mathrm{YPO}_{4}$ phase when the cell was operated in $\mathrm{PH}_{3}$ contaminated syngas that was not observed at the $\mathrm{Ni} / Y S Z / Y S Z$ triple grain boundary when the cell was operated in $\mathrm{PH}_{3}$ contaminated $\mathrm{H}_{2}$. In Figure 2.5 the $\mathrm{YPO}_{4}$ phase is the precipitate indicated by the arrows. 

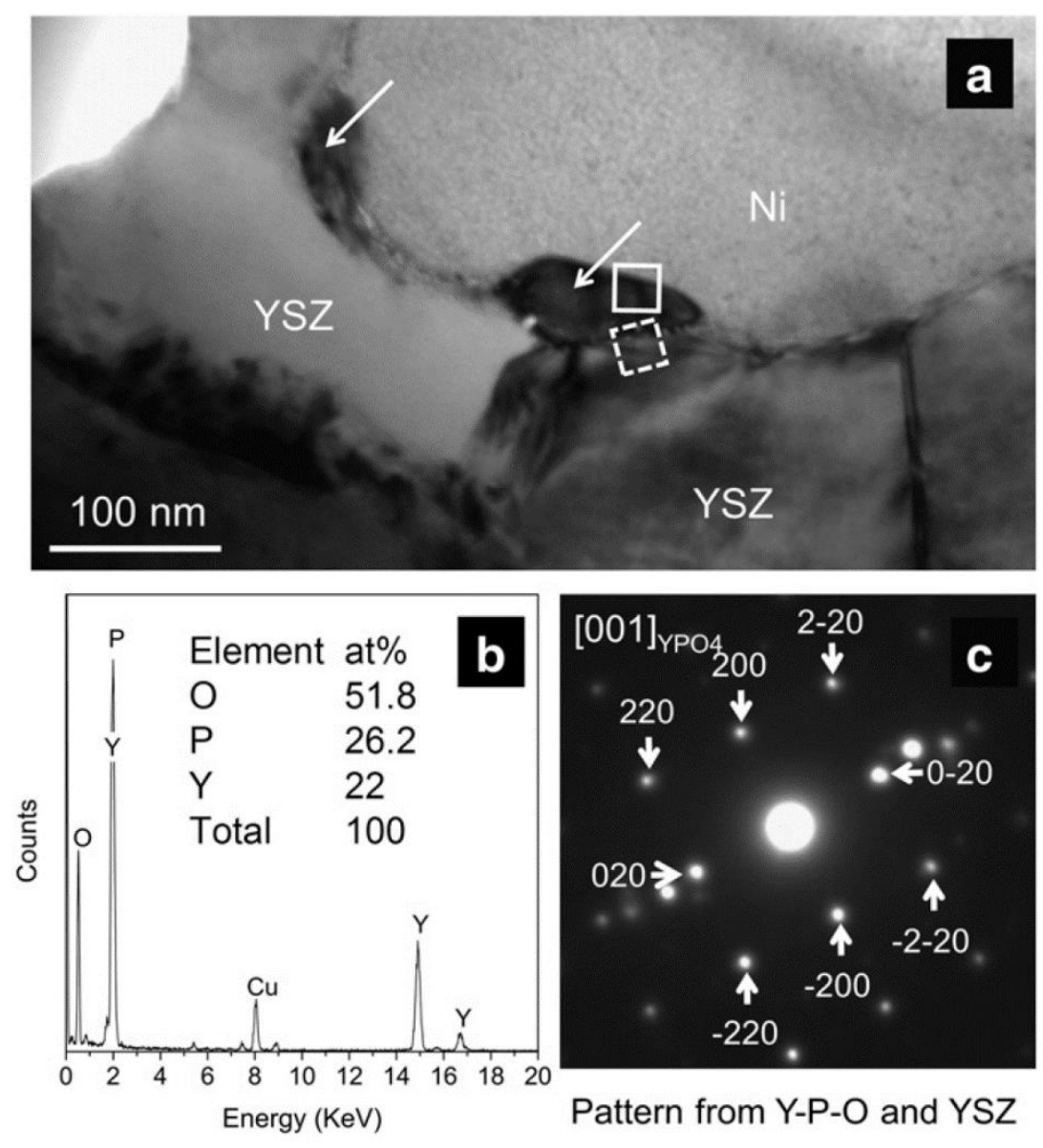

Figure 2.5 (a) TEM image indicating $\mathrm{YPO}_{4}$ precipitate formation in $\mathrm{PH}_{3}$ contaminated syngas (b) spectra indicating composition (c) selected area diffraction pattern [33].

Li et al. [34], using a Ni/YSZ anode-supported ( 0.4 $\mathrm{mm}$ thick), found that at $750^{\circ} \mathrm{C}$, the addition of $10 \mathrm{ppm}$ of $\mathrm{PH}_{3}$ caused an identical degradation rate of $1.68 \mathrm{mV} / \mathrm{h}$ between simulated coal-syngas and hydrogen. However, at $850^{\circ} \mathrm{C}$ there is a slight increase in the degradation rate for $\mathrm{PH}_{3}$ in the syngas over the $\mathrm{PH}_{3}$ in hydrogen. The results at $750^{\circ} \mathrm{C}$ disagree with the results of Chen et al. [33], which was operated at 800 ${ }^{\circ} \mathrm{C}$, while the results at $850^{\circ} \mathrm{C}$ from Li et al. [34] are similar those of Chen et al. [33]. 
Marina et al. [35] tested anode- and electrolyte-supported button cells at temperatures of $700-800^{\circ} \mathrm{C}$ with syngas containing $0.5-10 \mathrm{ppm}$ phosphine. Electrolytesupported cells degraded quickly and the degradation rate did not exhibit dependence on temperature or current density. The anode-supported cells also degraded, but not as rapidly as the electrolyte-supported cells. Larger exposure times were required due to the greater amount of nickel present in anode-supported cells. In Figure 2.6, the increase in the cell resistance of the electrolyte-supported cells is compared to the anode-supported cells at $800^{\circ} \mathrm{C}$. As noted in [32], [33], and [34] a series of nickel phosphide phases, $\mathrm{Ni}_{3} \mathrm{P}, \mathrm{Ni}_{5} \mathrm{P}_{2}, \mathrm{Ni}_{12} \mathrm{P}_{5}$ and $\mathrm{Ni}_{2} \mathrm{P}$, was observed in the anodes for both the electrolyte-supported and anode-supported cells.
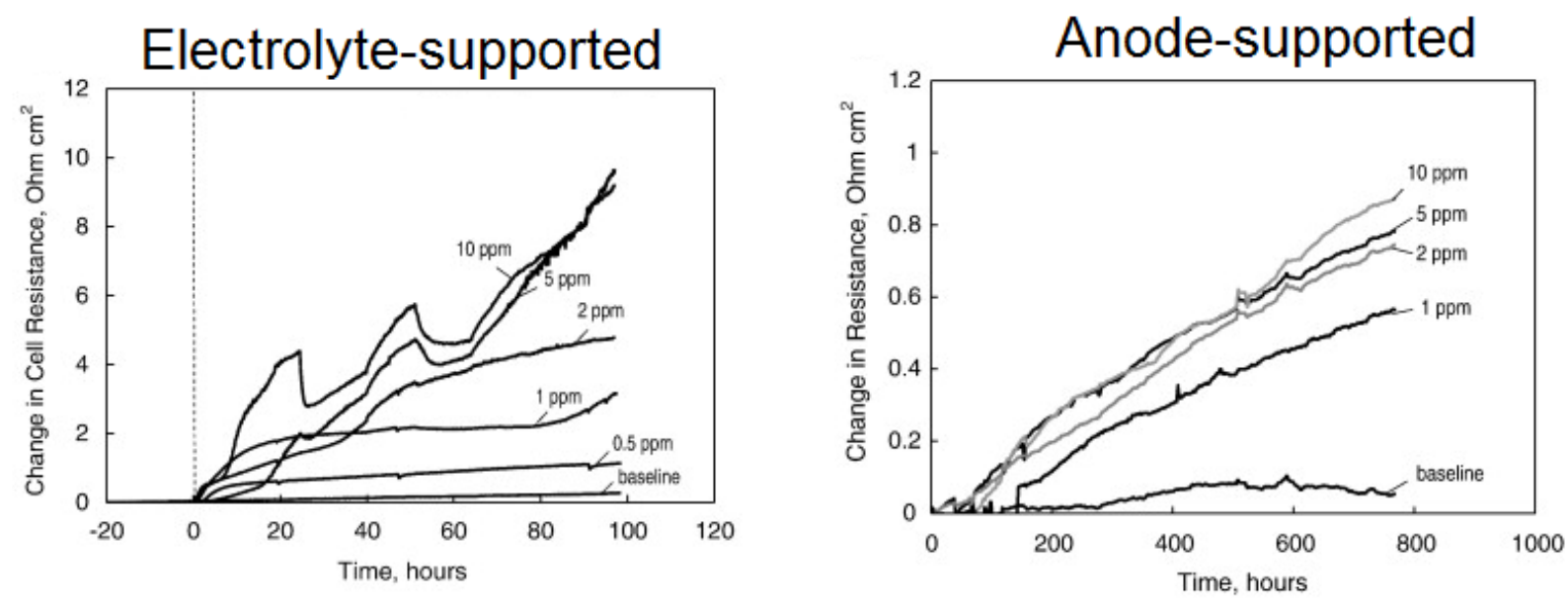

Figure 2.6 Electrolyte-supported cell resistance increases an order of magnitude faster than the anode-supported cell at $800^{\circ} \mathrm{C}$ over various concentrations, adapted from [35.]

Marina et al. [35] also simulated the potential nickel-phosphorus interactions in a planar SOFC stack by flowing syngas contaminated with $0.5 \mathrm{ppm} \mathrm{PH}_{3}$ parallel to the surface of a Ni/YSZ coupon ("flow-by" configuration) at $800^{\circ} \mathrm{C}$. These coupons were not operated electrochemically. At the gas inlet (right side of Figure 2.9), the phosphine 
immediately reacted with the nickel. No phosphorus $(\mathrm{P})$ uptake was observed after a distance of $\sim 4 \mathrm{~mm}$ from the inlet. Figure 2.7 also shows the agglomeration of $\mathrm{Nix}_{x} \mathrm{P}_{y}$ at the surface and penetration of $\mathrm{Nix}_{x} \mathrm{P}_{\mathrm{y}}$ into the surface of the $\mathrm{Ni} / \mathrm{YSZ}$ coupon. It is possible that as the $\mathrm{Ni} / \mathrm{YSZ}$ becomes saturated with $\mathrm{P}$, it would continue moving as a zone across the coupon.

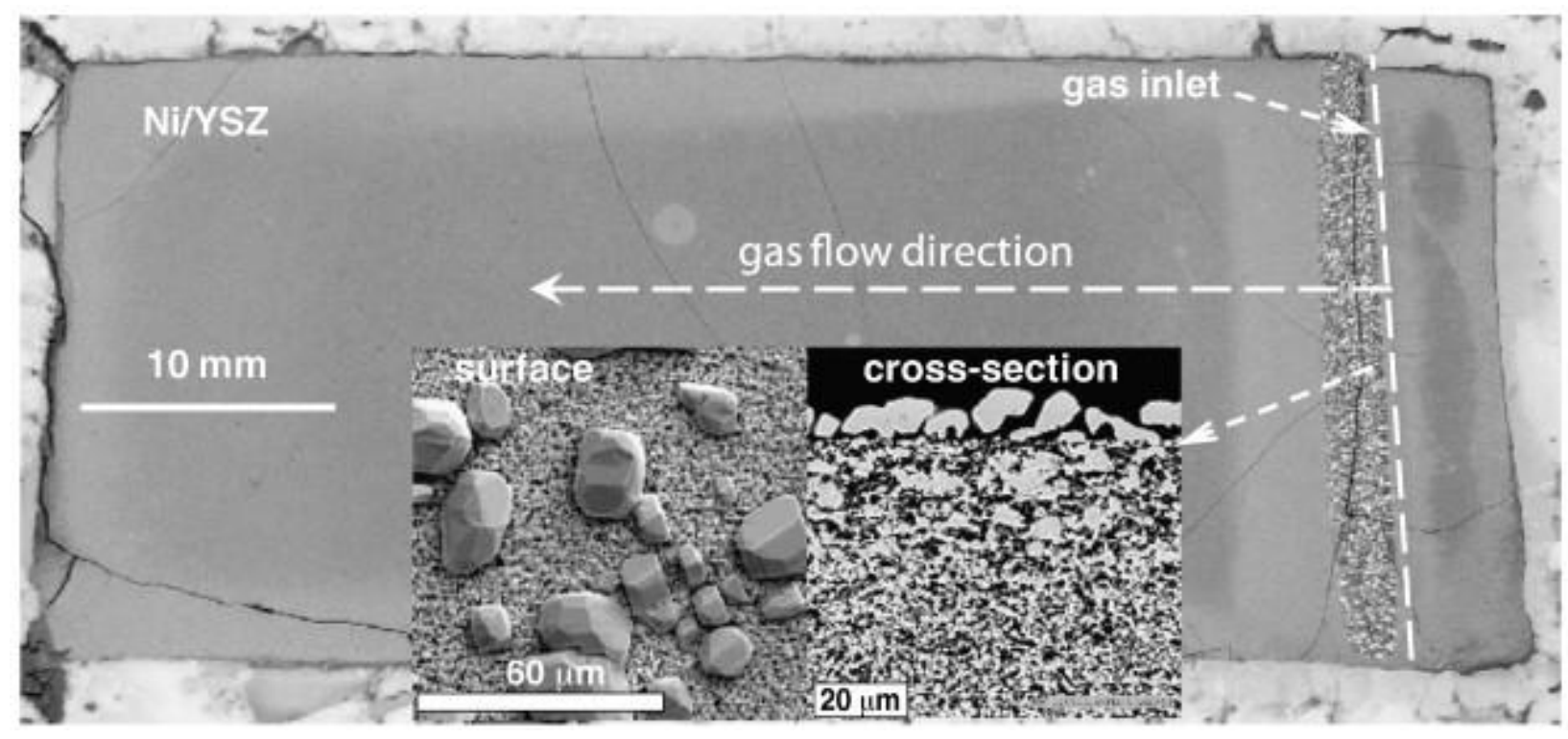

Figure 2.7 Ni/YSZ coupon after exposure to synthetic coal gas containing $0.5 \mathrm{ppm}$ phosphine flowed lengthwise across the coupon at a rate of $3.4 \mathrm{~cm}^{3} \mathrm{gas}$ per $\mathrm{cm}^{2}$ of cross-sectional area per second $\left(\mathrm{cm}^{3} \mathrm{gas} / \mathrm{cm}^{2} / \mathrm{sec}\right)$ for $75 \mathrm{~h}$ [G10]

2.5 Impurity Modeling of Fuel Cells

Performing experiments in the laboratory requires significant capital investments and funding. The rise of inexpensive, high-powered computing has made computer modeling and simulation of complex fuel cell processes viable. There are a large number of parameters that can be included in these models that depend on the specific SOFC process being employed: mass/energy/momentum transfer, diffusion through porous media, electrochemical reactions with and without $\mathrm{CO}$ oxidation, shift and 
reforming reactions, and polarization losses inside the subsystems. These models can provide a picture of voltage, current density, temperature, velocity and concentration of components as functions of position and time for various cell configurations and operating conditions. Comprehensive reviews such as Kakac et al. [G36] Hajimolana et al. [37], and Grew and Chiu [38], compare the multitude of approaches to modeling these parameters.

Impurity modeling has the added challenge of incorporating parameters detailing the changes that occur when contaminants reach the electrodes. The kinetics of additional reactions are not always well-understood so experimentation is necessary to validate the results.

Sezer et al. [39] incorporated a one-dimensional degradation model into a threedimensional modeling code (DREAM-SOFC). The one-dimensional model calibrates the model parameters with experiments. These calibrated parameters are then applied to planar SOFC simulations. This model is specifically used to evaluate the phosphine induced degradation pattern. The implemented code takes into account the transport of the fuel and oxidizer and the chemical kinetics of the hydrogen-oxidation reaction that is catalyzed by Ni. DREAM-SOFC predicts temperature, electrical potential, current density, Ni coverage, Ni deactivation, and the spatial distribution of species inside the anode and the cathode.

Table 2.3 gives the geometry and operating conditions of the planar SOFC simulated in DREAM-SOFC [39]. The simulation parameters are very similar to the physical testing setup used for this project. The results of the present experiments can be used to validate and improve DREAM-SOFC. 
Table 2.3 DREAM SOFC planar solid oxide fuel cell parameters [39].

\begin{tabular}{|c|c|}
\hline \multicolumn{2}{|c|}{ Geometry Parameters of the planar SOFC } \\
\hline Anode thickness & $50 \mu \mathrm{m}$ \\
\hline Electrolyte thickness & $170 \mu \mathrm{m}$ \\
\hline Cathode thickness & $50 \mu \mathrm{m}$ \\
\hline Fuel channel height & $2.5 \mathrm{~mm}$ \\
\hline Air Channel height & $2.5 \mathrm{~mm}$ \\
\hline Cell length & $5 \mathrm{~cm}$ \\
\hline Current collector width & $1.28 \mathrm{~mm}$ \\
\hline Channel width & $3 \mathrm{~mm}$ \\
\hline \multicolumn{2}{|c|}{ Conditions and parameters for simulation } \\
\hline Fuel inlet composition & $99.99 \% \mathrm{H} 2+$ \\
\hline (Mole fractions) & 10ppm PH3 \\
\hline Fuel inlet temperature $(\mathrm{K})$ & 1073 \\
\hline $\begin{array}{l}\text { Air inlet Composition (Mole } \\
\text { fractions) }\end{array}$ & $21 \%$ O2 \\
\hline Air inlet temperature $(\mathrm{K})$ & 1073 \\
\hline Pressure (atm) & 1.01325 \\
\hline External Boundaries & Adiabatic \\
\hline Current density $(\mathrm{A} / \mathrm{cm} 2)$ & 0.1 \\
\hline Fuel Utilization (\%) & 12.5 \\
\hline Air Utilization (\%) & 1.25 \\
\hline Anode porosity & 0.480 \\
\hline Cathode porosity & 0.45 \\
\hline
\end{tabular}

Figure 2.8 shows the predicted $32 \%$ voltage loss within 6 hours of exposure to 10 ppm of $\mathrm{PH}_{3}$ in $\mathrm{H}_{2}$. The anode deactivation is spatially non-uniform which alters the current distribution inside the cell. Current redistribution results in hydrogen starvation at the active regions and variable polarization resistance in different regions of the cell. Figure 2.9 shows the changing hydrogen mass fraction at the anode/electrolyte interface [39]. 


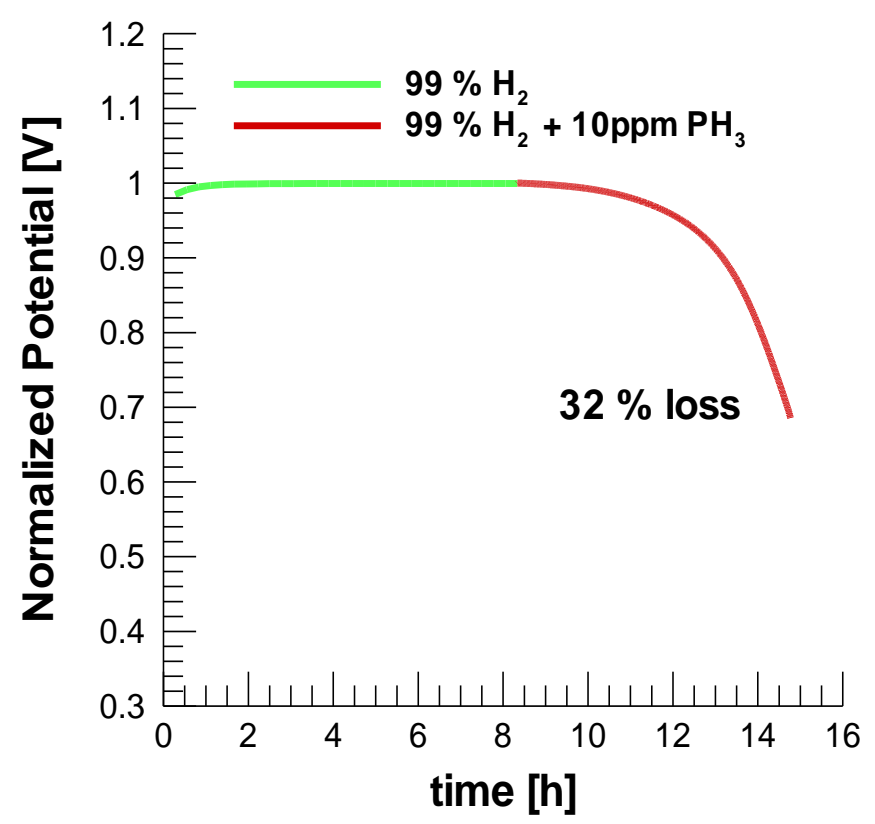

Figure 2.8 Rapid voltage loss at $0.1 \mathrm{~A} \mathrm{~cm}^{-2}$ as a result of introduction of 10 ppm $\mathrm{PH}_{3}$ in $\mathrm{H}_{2}$ [39].
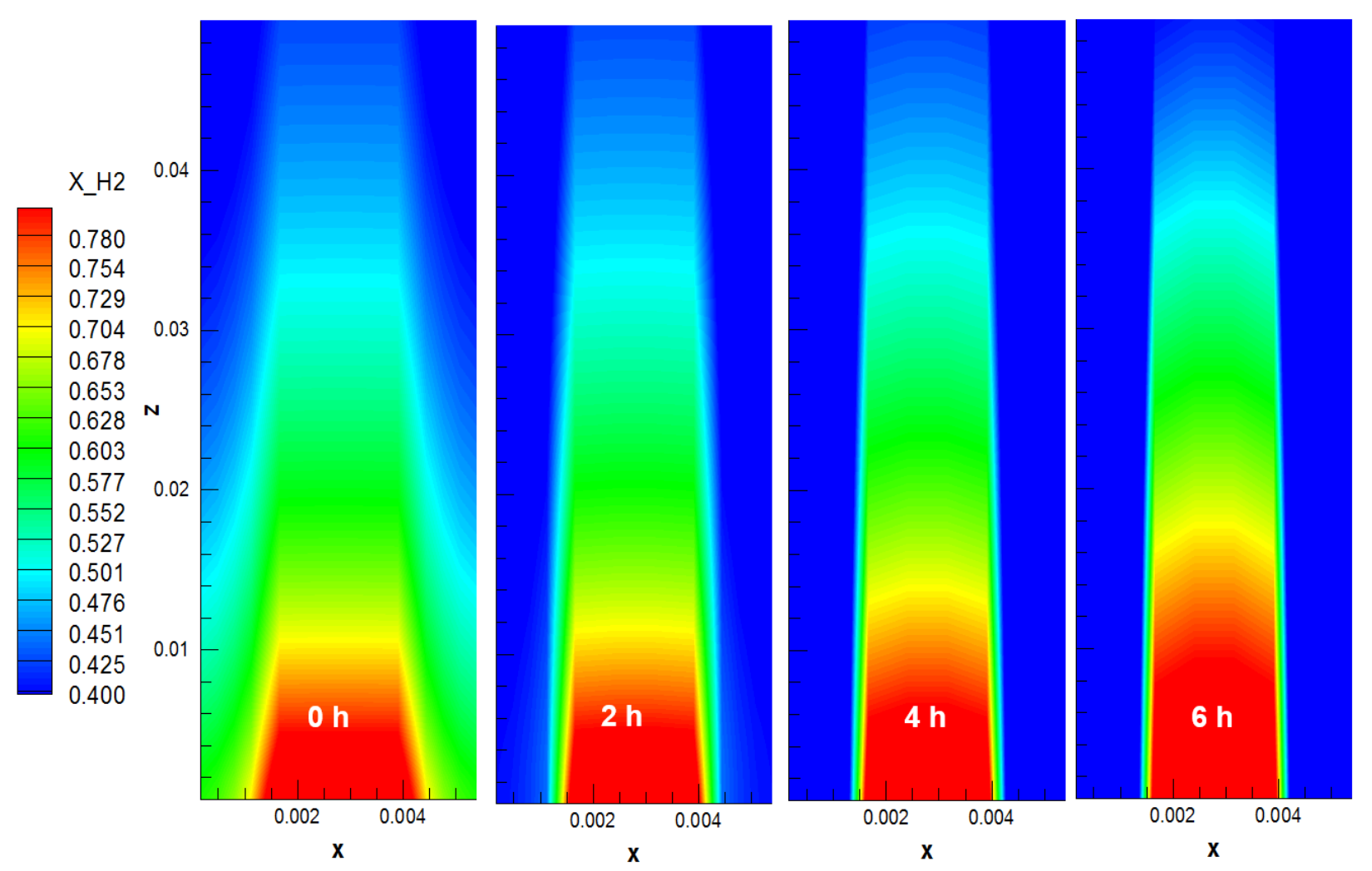

Figure 2.9 Contours of $\mathrm{H}_{2}$ mass fraction at anode/electrolyte interface at different $\mathrm{PH}_{3}$ exposure times [39]. 
The model predicts the deactivation of the anode of the planar cell due to the phosphine poisoning to be spatially non-uniform. This differs from button cells, where the deactivation of the anode is spatially uniform. The current distribution being altered has a number of effects. The current redistribution results in hydrogen starvation at the active regions and temperature redistribution. The ohmic resistance changes with time and the polarization resistances change at different regions of the cell. These all lead to voltage and current oscillations [39]. An additional goal of this experiment was to experimentally validate the changes predicted by the DREAM SOFC model. 


\section{Chapter 3: Experimental Procedures}

\subsection{Experimental Approach}

In this work, the performance of large, planar, solid oxide fuel cells (SOFC) was investigated along with their degradation rate for phosphine poisoning of the nickel-based anode. Potential variables were the fuel utilization and fuel delivery as seen in a co-flow configuration in a planar fuel cell stack at a near-industrial scale. Co-flow configuration for the gases is different than typical button cell testing, in that the gases will flow parallel to the cell face rather than perpendicular to the cell face. Figure 3.1 shows a typical button cell testing stand.

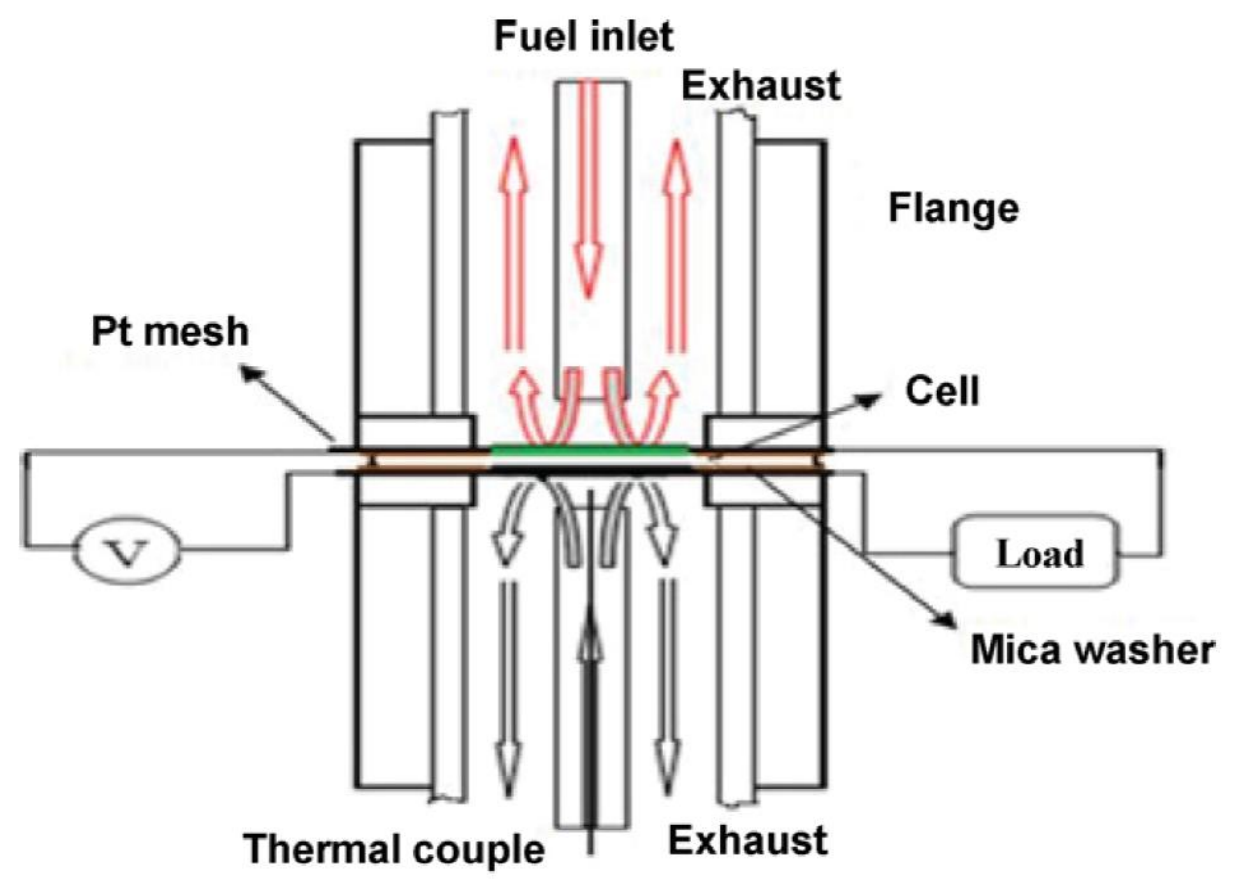

Air inlet

Figure 3.1 Typical button cell testing stand. The small button cells are sandwiched between flanges that allow flow of the gases directly at the cell face [40]. 
Typical button cells are circular in shape (hence the name "button") and have small active areas $\left(1-2 \mathrm{~cm}^{2}\right)$, whereas the square planar cells used in this project have an active area 16 times greater $\left(\sim 32 \mathrm{~cm}^{2}\right)$. These smaller size cells can be useful in the laboratory, but their performance is not necessarily indicative of industrial scale applications. Guan and Wang [41] found 10-cell and 5-cell stacks had performance considerably lower than that of a single unit cell $\left(0.4 \mathrm{~W} \mathrm{~cm}^{-2} \mathrm{vs.} 1.0 \mathrm{~W} \mathrm{~cm}^{-2}\right)$. They also noted that large-scale commercial stacks have active areas of $100-500 \mathrm{~cm}^{2}$ or even larger. They attributed the performance decrease to a number of factors: (1) the larger the scale, the more difficult it is to control the microstructure of the unit cell during mass production; (2) the larger the scale, the more difficult it is to collect electrons during cell testing; (3) the larger the scale, the more evenly the gas distributes, and (4) the larger scale leads to an uneven temperature distribution.

This project started with the design of the fuel cell stand and the fabrication of the manifolds to be used for testing a large $(10 \mathrm{~cm} \times 10 \mathrm{~cm})$ planar SOFC. All testing was performed with commercially available $\mathrm{Ni}$-anode, electrolyte-supported, planar, fuel cells (product no. 213209) manufactured by NexTech Materials, Ltd. The two manifolds were designed to be similar to planar repeat stacks at the industrial scale and were machined from Haynes ${ }^{\circledR} 242^{\circledR}$ (Haynes International), with one gas inlet and one gas exhaust tube of Incone ${ }^{\circledR} 601$ (Special Metals Corporation) per manifold. A typical planar stack is shown in Figure 3.2. The test stand is composed of the furnace that houses the manifolds, the piping system to deliver the gases to the fuel-cell manifolds, and the electrical and computer equipment for monitoring the performance of the cell. 


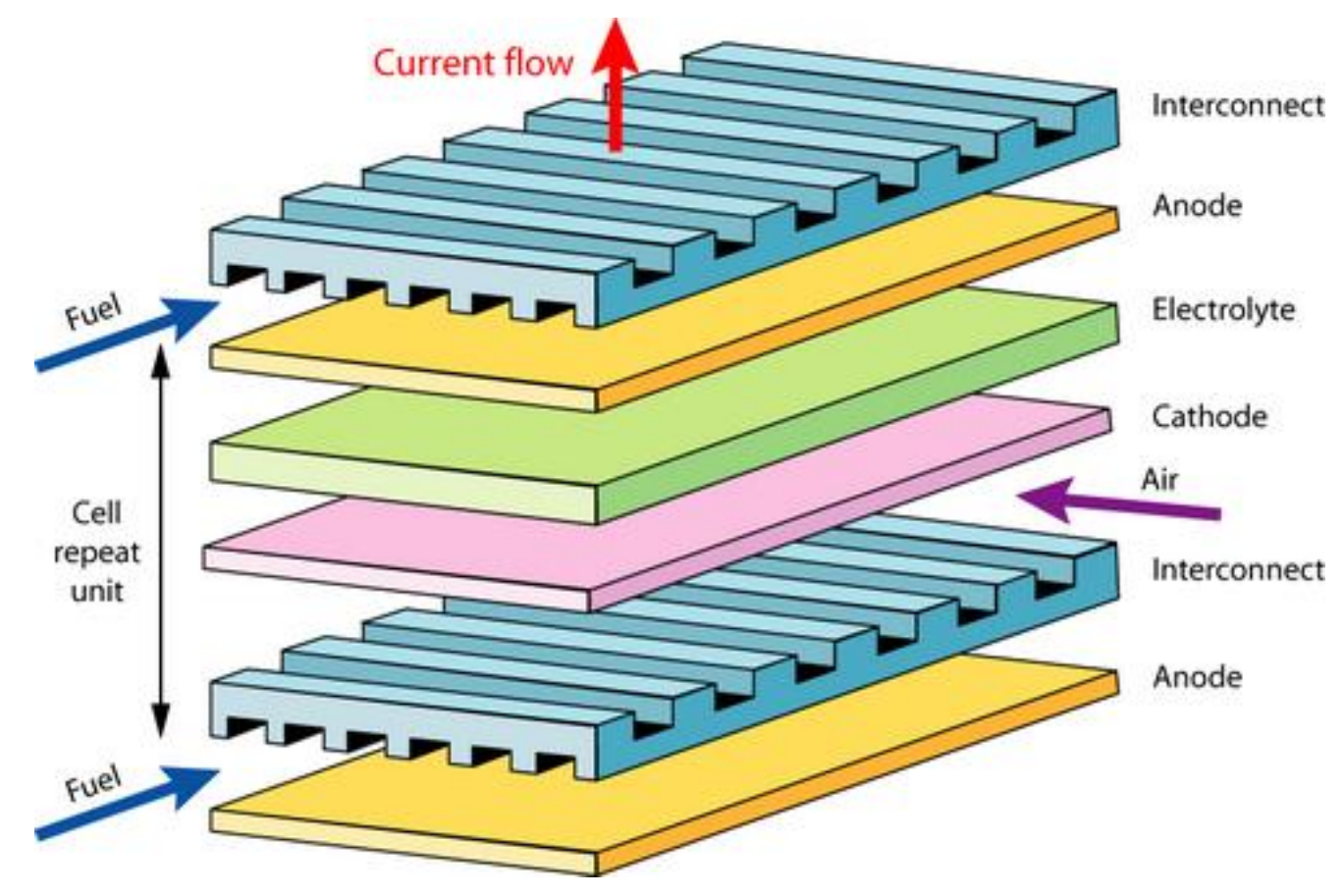

Figure 3.2 Planar repeat cell stack for large scale power generation [42]. Each unit cell (anode, electrolyte, and cathode), with sealing materials and interconnects, are repeated until the desired power output it achieved [41].

The cell assembly procedure was established. This methodology was used to assemble each subsequent cell. Baseline testing was conducted to establish the typical performance of the cells. This baseline testing employed pure, dry $\mathrm{H}_{2}$ as the anode fuel gas. Once this baseline was established, it was extended to compare the effects of feeding $10 \mathrm{ppm} \mathrm{PH}_{3}$ in $\mathrm{H}_{2}$ to the anode.

The data from the phosphine runs were compared to the baseline hydrogen tests. This included monitoring cell voltage over time at a constant current load and/or fuel utilization, voltage-current measurements, impedance spectroscopy, and all of the pre- and post-test material characterization. 


\subsection{Experimental Setup}

The experimental setup included the gas cylinders, piping system, planar SOFC, and the SOFC testing stand. Figure 3.3 displays the diagram of the experimental system. Air flows directly to the cathode manifold and does not combine with any other gases. Hydrogen, nitrogen, and the $10 \mathrm{ppm} \mathrm{PH}_{3}$ in $\mathrm{H}_{2}$ are contained in three separate cylinders and are connected to the anode manifold using only stainless steel tubing.

Due to the high flammability of hydrogen and the high operating temperature of the furnace, the gas cylinders are located in a separate walk-in fume hood and are isolated from the furnace. The piping between the fuel cell and gas cylinders runs through the wall of the fume hoods. There is a sampling port to measure the inlet concentration of the phosphine by means of a photoionization detector (RAE Systems, MultiRAE Plus) before it reaches the fuel cell. This sampling port is contained within its own walk-in fume hood, separate from both the cylinders and the furnace. The concentration of phosphine in the fuel cell exhaust is also measured with the same photoionization detector. The flow rate of each gas is controlled by means of Alicat Scientific mass flow controllers (MC Series). These flow controllers have an accuracy of $\pm(0.8 \%$ of reading $+0.2 \%$ of full scale $)$. 


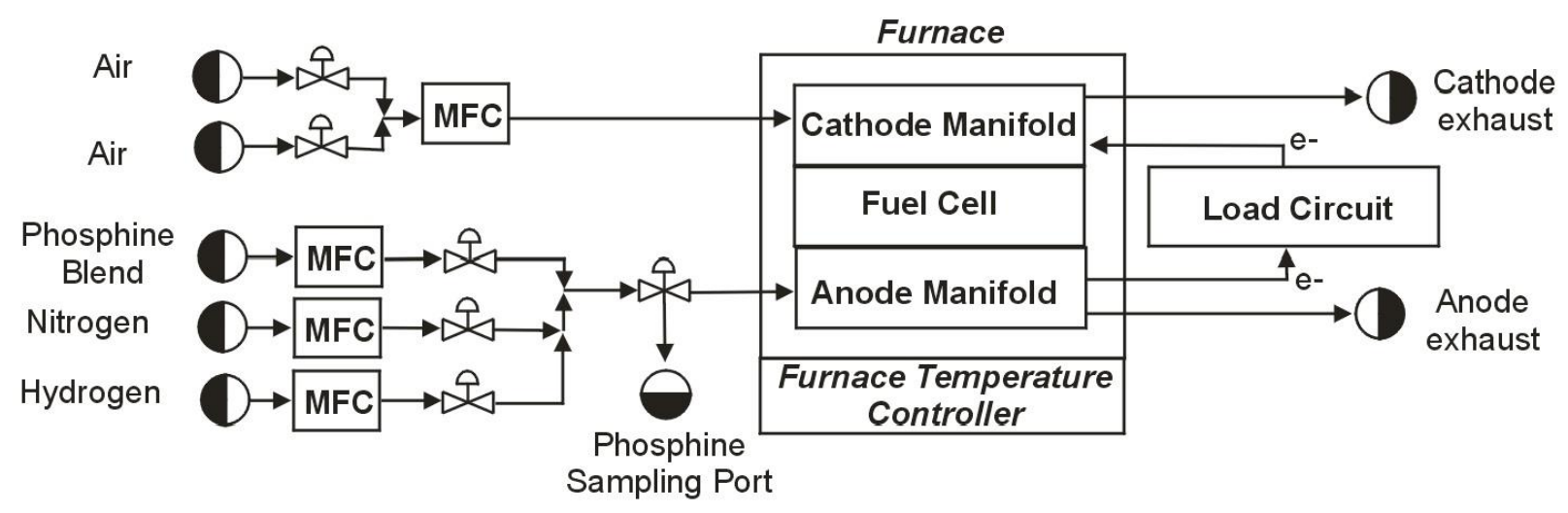

Figure 3.3 Diagram of fuel cell test stand shows the gas distribution system, furnace for heating the SOFC, and the external load circuit.

The fuel cell assembly (fuel cell, current collectors, gaskets, and manifolds) is contained within the furnace (Paragon, Model S1262). Current load is imposed on the fuel cell by an electronic load cell (TDI, Model SDL 1103). A constant voltage power supply (BK Precision, Model 9150) is also installed in series with the load cell to bias the circuit voltage higher due to the specific low-voltage limitations of the load cell. The load cell requires a certain minimum voltage to operate in the correct current range. The power supply raises the total circuit voltage by 3 volts. This allows the load cell to continue increasing current as the voltage of the fuel cell drops to near zero. Figure 3.4 is a diagram of this circuit. 


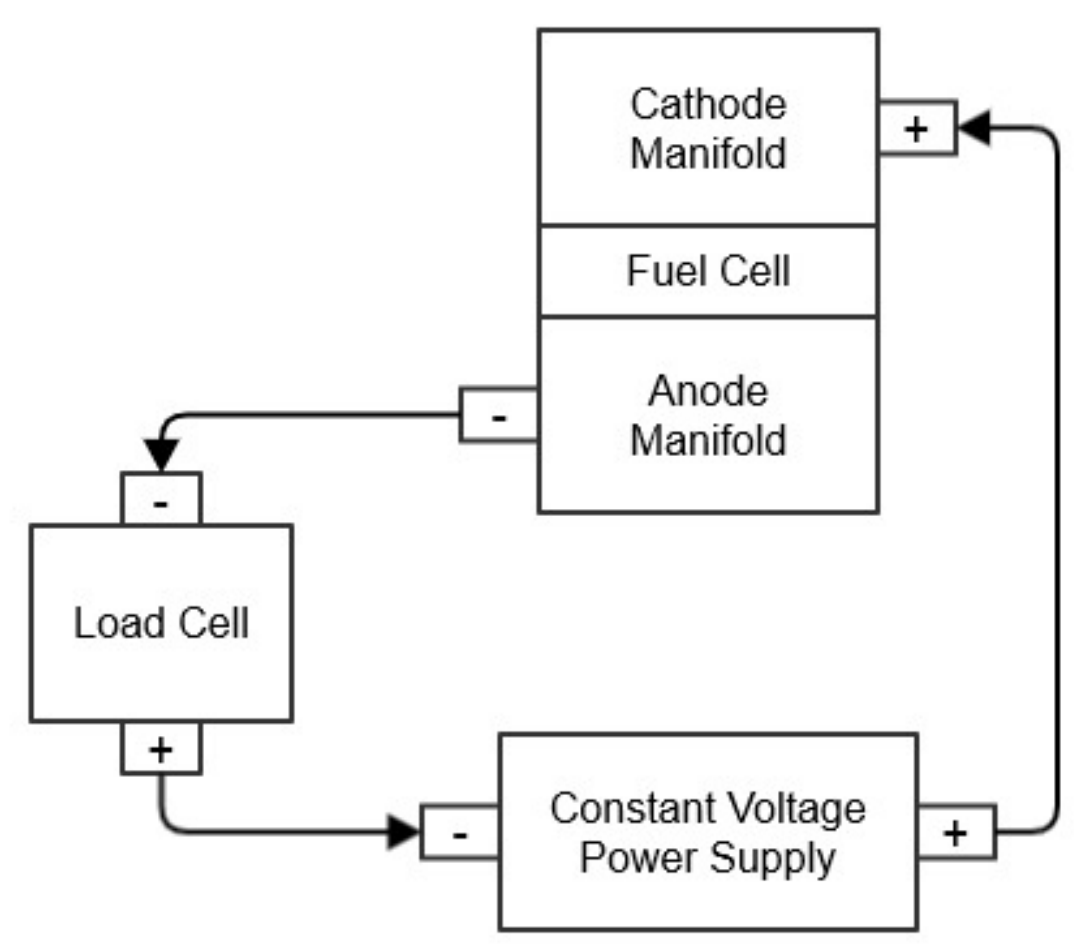

Figure 3.4 Circuit diagram with boost power supply installed in series with the SOFC and load cell.

\subsection{Experimental Methods}

\subsubsection{Cell Assembly}

The fuel cell is a large $(10 \mathrm{~cm} \times 10 \mathrm{~cm})$, planar cell produced by NexTech Materials, Ltd in Lewis Center, Ohio and is shown in Figure 3.3. It is an electrolyte supported cell with an active area of $32.64 \mathrm{~cm}^{2}$. For these cells, the anode electrode is $50 \mu \mathrm{m}$ thick NiO-GDC/NiO-YSZ and the cathode electrode is $50 \mu \mathrm{m}$ thick LSM/LSMGDC. The electrolyte is a Scandia-based Hionic ${ }^{\mathrm{TM}}$ support and is $130-170 \mu \mathrm{m}$ thick [50]. This is a proprietary scandia-zirconia (ScZ) electrolyte developed by NexTech Materials, Ltd. 


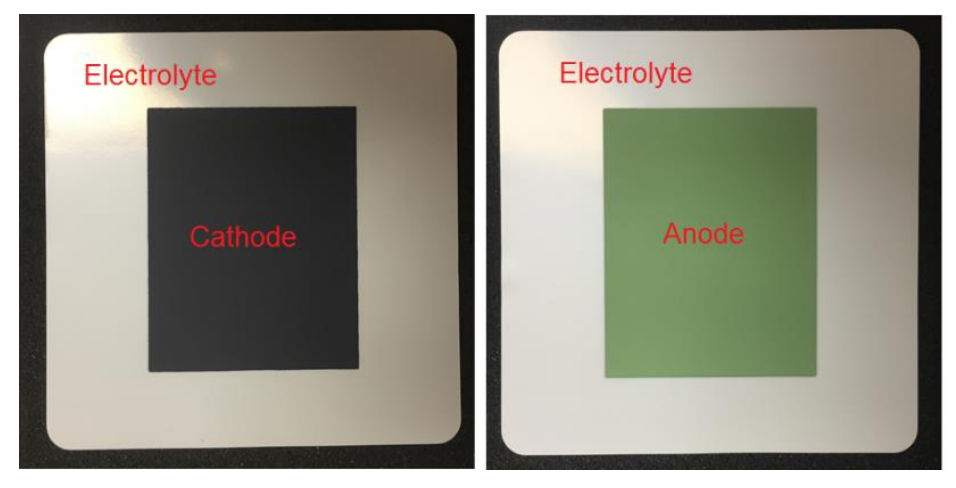

Figure 3.3 Left is the LSM/LSM-GDC cathode and right is the NiOGDC/NiO-YSZ anode of the NEXTCELL ${ }^{\mathrm{TM}}{ }_{-7}$ produced by NexTech Materials, Ltd.

The two manifolds were machined from Haynes ${ }^{\circledR} 242^{\circledR}$ (Haynes International), a nickel-molybdenum-chromium alloy, with one gas inlet and one gas exhaust tube of Incone ${ }^{\circledR} 601$ (Special Metals Corporation), a nickel-chromium alloy, per manifold, as shown in Figure 3.4. These materials were chosen because of their high-temperature strength, low thermal expansion characteristics, oxidation-resistance, and corrosionresistance $[43,44]$. 


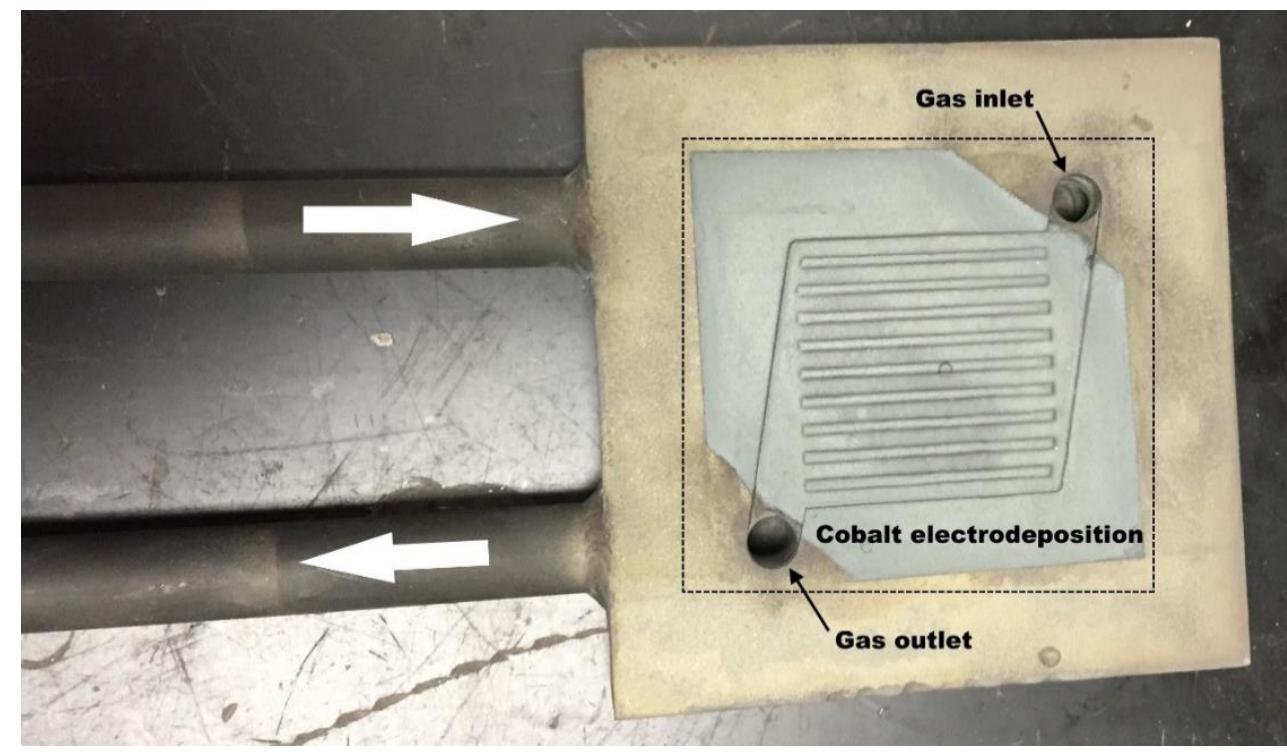

Figure 3.4 Haynes ${ }^{\circledR} 242$ alloy manifold with Co electrodeposition. The Co is the area inside of the dashed box. Co is only deposited where the active area of the cell contacts the manifold. Arrows indicate gas flow direction.

A layer of cobalt (Co) is electrodeposited on the surface of each manifold as an additional protective layer. It is primarily used to protect against excessive oxidation of the manifold, where the cobalt oxide passivates further oxidation and remains conductive. Another potential benefit is to protect the cathode from any chromium that may migrate to the manifold surface and poison the LSM in the cathode. Oxidation of the Co coating was done for 2 hours at $800^{\circ} \mathrm{C}$ in air [45]. The cobalt does not need to be deposited on the entire manifold face, as the outside edge is where the mica gaskets are eventually placed.

When the gases reach the cell interface from the gas inlet, they flow down the narrow channels to the outlet. The 10 channels are $4-\mathrm{cm}$ long, $3-\mathrm{mm}$ wide, and $1.5-\mathrm{mm}$ deep. The gases flow parallel across each cell face rather than perpendicular to the cell face and flow direction is indicated in Figure 3.4. 
Two high-temperature mica sheets (McMaster Carr) are cut to their specific shape, shown in Figure 3.5, using a laser cutter and are used as gaskets to seal the cell. A number of trials were required to determine the optimal number of sheets to seal the cell. One sheet is solid and contacts the manifold. The second sheet sits on top of the first sheet, and has a very thin slot to allow the voltage tap wire to pass through. The mica initially starts as a flat, laminated sheet. Upon heating, the mica expands a small amount $(\sim 0.05 \mathrm{~mm})$. This expansions prevents the gases from leaking.
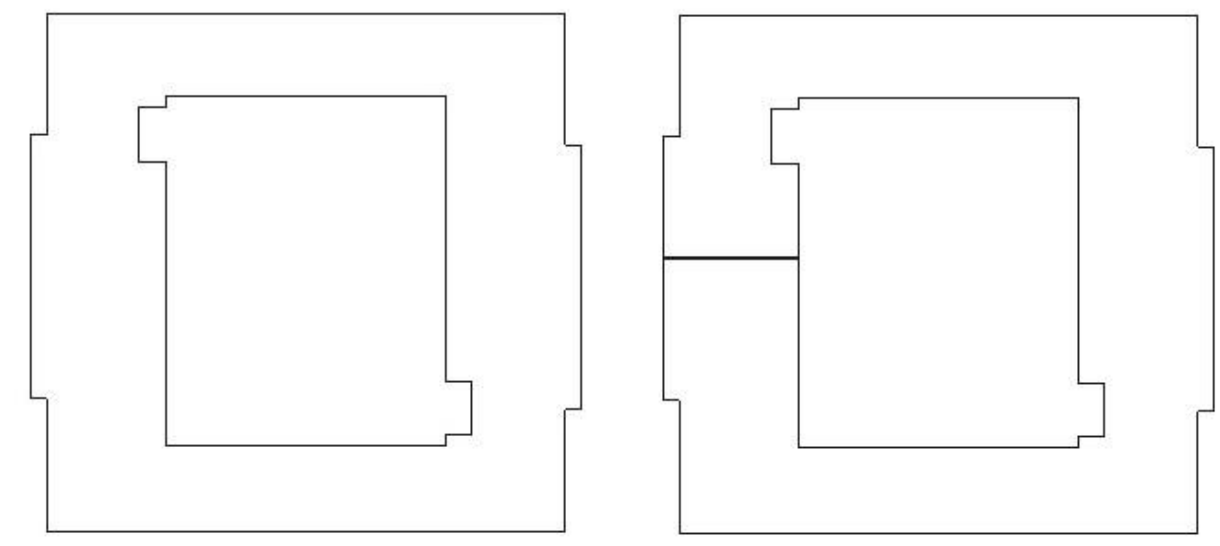

Figure 3.5 Mica schematics for use in cutting the mica gaskets with the laser cutter. The gasket on the left (without the slot) contacts the manifold. The sheet on the right contacts the fuel cell and has a slot for the voltage tap to pass through.

Platinum mesh (Unique Wire Weaving Company), $50 \mathrm{~mm}$ x $50 \mathrm{~mm}$ in size, serves as the current collector at each electrode and is attached to the electrodes using platinum powder (Technic, Inc.) in an ink vehicle that forms a paste. Platinum wires (Surepure Chemetals) $0.25 \mathrm{~mm}$ diameter in size (with silver wire extensions to reach the outside of the furnace) are used as voltage taps for the electrical measurements in a four-point configuration. These wires are attached to the cell using the same platinum 
paste. Platinum materials are used so that the phosphine will only interact with the nickel in the anode. The details of the assembly of the cell are shown in Figure 3.6.

The manifolds are sandblasted and thoroughly cleaned before electrodeposition of the cobalt occurs. Figure 3.6 (a) shows the cobalt layer electroplated on the anode surface again. Figure 3.6 (b) platinum paste is carefully painted using a foam brush onto the tops of the ridges. Any paste that flows down into the valleys between the ridges is removed. The platinum paste here ensures electrical conductivity between the cell and the manifolds. The platinum mesh current collector is carefully placed on top of the ridges. The two mica gaskets are then placed on top of the manifold. From Figure 3.6 (c), the mica gaskets cover the outside edge of the manifold and contact only the electrolyte portion of the fuel cell. The second mica sheet (or top sheet) has a thin slit cut in the side to allow the platinum voltage tap to extend out and away from the cell interface.

There is a layer of platinum paste painted onto the electrode before the fuel cell is placed onto the manifolds. This is again done to ensure electrical conductivity between all components. The cell is then placed on top of the manifold. The entire process is then repeated for the second manifold. Once both manifolds have all platinum components and mica gaskets, the second manifold is placed on top of the first manifold. Figure 3.6 (f) shows both manifolds in position to be loaded into the furnace. Both electrode voltage taps can be seen extending out of either side of the cell. A small amount of tape is used to help keep the components together as the manifolds are loaded into the furnace. 

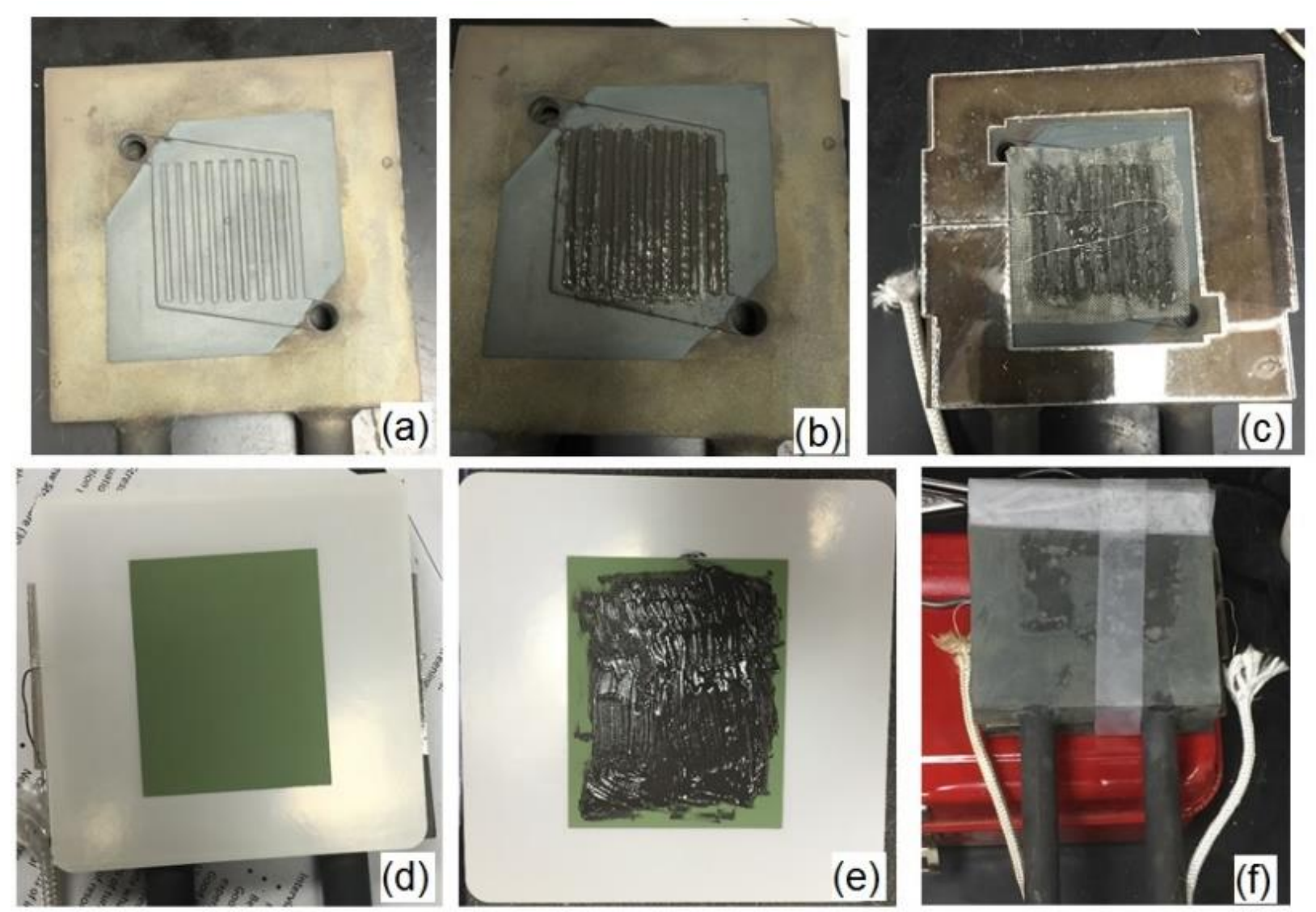

Figure 3.6 (a) Manifold with Co electrodeposition (b) Pt paste on tops of ridges. This helps ensure electrical conductivity between the cell and the manifolds (c) Pt mesh on top of ridges with Pt voltage tap in "J" shape extending out left side. There is a slit on the second (or top) mica gasket to allow the voltage tap to extend to the outside of the furnace. (d) Fuel cell placed on top of cathode (e) Layer of Pt paste applied over top of fuel cell to ensure electrical conductivity between all components ( $f$ ) Completed assembly with both manifolds sandwiching the fuel cell to be inserted into the furnace.

The Incone $\left.\right|^{\circledR}$ pipes and each manifold serve as the current collector. Heavy wires are firmly attached to the ends of the Inconel pipes to send current to the load cells as shown in Figure 3.7. Heating tape is wrapped around the inlet and exhaust tubes of the manifolds to preheat the inlet gases and help prevent the condensation of water vapor in the outlet gas. Figure 3.8 shows the manifolds loaded into the furnace with gas lines connected. 


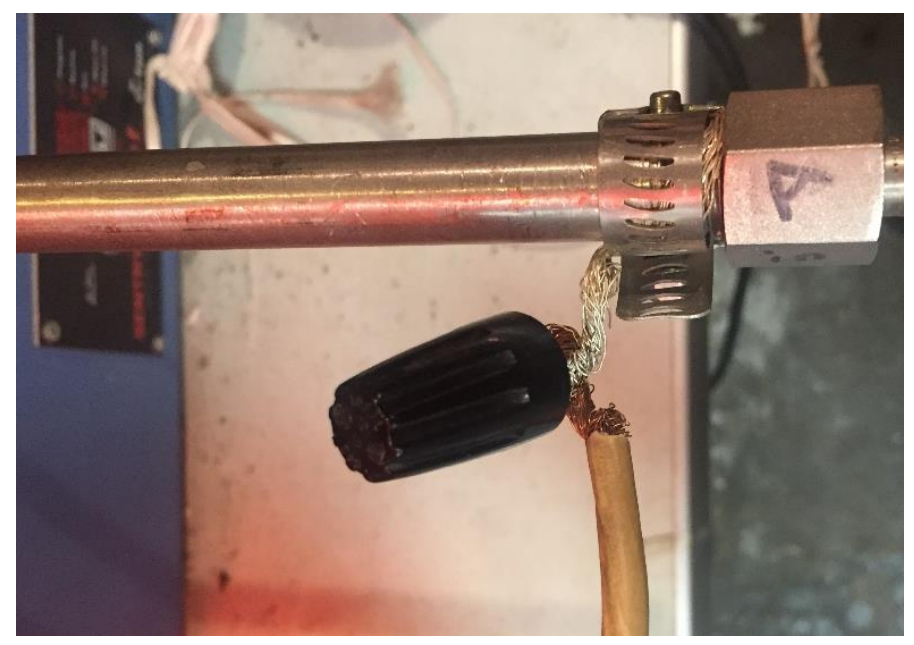

Figure 3.7 Load cell securely connected to end of manifold using wire nuts and clamps.

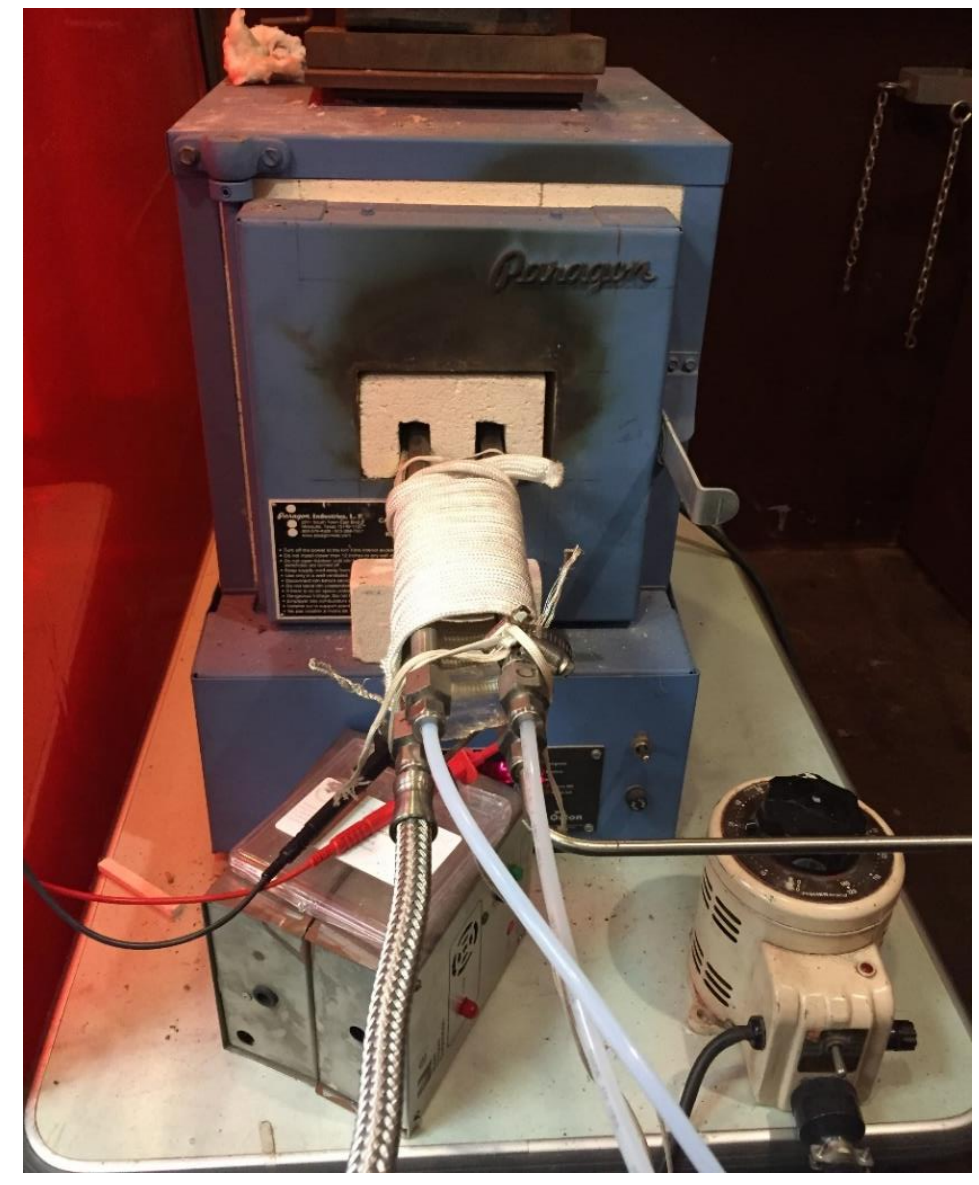

Figure 3.8 Manifold assembly loaded into the furnace with fuel lines connected. The weights used to apply pressure onto the stack, heating tape, and voltage measuring leads are also visible. 


\subsubsection{Cell Operation}

After the cell is assembled, it is placed in a furnace and heated to $800^{\circ} \mathrm{C}$ at a rate of $1^{\circ} \mathrm{C} \mathrm{min}-1$. An $11 \mathrm{~kg}$ weight is added to the top of the fuel cell stack to apply $\sim 18 \mathrm{kPa}$ pressure to the gaskets that seals the assembly. This minimizes gas leakage and also helps with electrical conductivity. During heat-up, nitrogen is fed to the anode at 100 SCCM and air is fed to the cathode at $100 \mathrm{SCCM}$. Upon reaching $800^{\circ} \mathrm{C}$, the anode is switched to 99 SCCM nitrogen and 1 SCCM hydrogen, while the cathode is fed the same 100 SCCM air. Over a four- hour period, the nitrogen flow rate to the anode is gradually decreased from 99 to 0 SCCM and the hydrogen flow rate is gradually increased from 1 to 100 SCCM to reduce the nickel in the anode from NiO to Ni. For

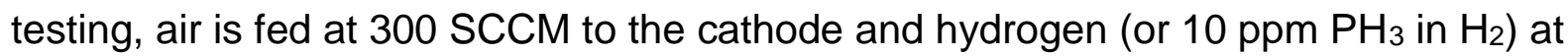
200 SCCM is fed to the anode.

When not collecting polarization curves or impedance spectra, the cell is loaded to a constant current density of $100 \mathrm{~mA} \mathrm{~cm}^{-2}$. This current density corresponds to a fuel utilization of $12.5 \%$. Fuel utilization represents a fraction of the total fuel input, which is electrochemically oxidized by the oxide-ion current [46]. The voltage at this current density is continuously monitored.

During the poisoning tests, the concentration of phosphine in $\mathrm{H}_{2}$ being fed to the anode and at the exhaust is measured periodically by means of a photoionization detector (MultiRAE Plus) with the UV lamp set to $10.6 \mathrm{eV}$. The device was calibrated using isobutylene because the manufacturer provides a table of correction factors when isobutylene is used as the calibration gas. At the $10.6 \mathrm{eV}$ setting, the correction factor 
for $\mathrm{PH}_{3}$ is 3.9. The device reading is then manually multiplied by 3.9 to obtain the concentration of $\mathrm{PH}_{3}[47]$.

Once a particular test has been completed, the furnace is cooled to ambient temperature at a rate of $1^{\circ} \mathrm{C} / \mathrm{min}$. While cooling, air is fed to the cathode at $50 \mathrm{SCCM}$ and nitrogen at $25 \mathrm{SCCM}$ and $\mathrm{H} 2$ at $25 \mathrm{SCCM}$ are fed to the anode. Upon reaching ambient temperature, the manifold assembly is extracted from the furnace and the fuel cell removed from the manifold. The cell is immediately vacuum sealed and taken to a glovebox where it is stored in a nitrogen environment awaiting the material characterization. This is done to preserve the sample from air oxidation.

\subsubsection{SOFC Testing}

There are two primary measurements for evaluating the performance of a fuel cell. These measurements are the voltage response as electrical current is drawn (polarization curves) and electrochemical impedance spectroscopy (EIS).

\subsubsection{Polarization Curves}

The voltage output of the fuel cell is a function of the electrical current density. This is commonly displayed as a polarization curve, shown in Figure 3.9. The voltage decreases as current is increased and the various voltage losses originate from three polarization sources: activation, ohmic, and concentration polarizations. These can be analyzed individually, but they do not act independently of each other. 


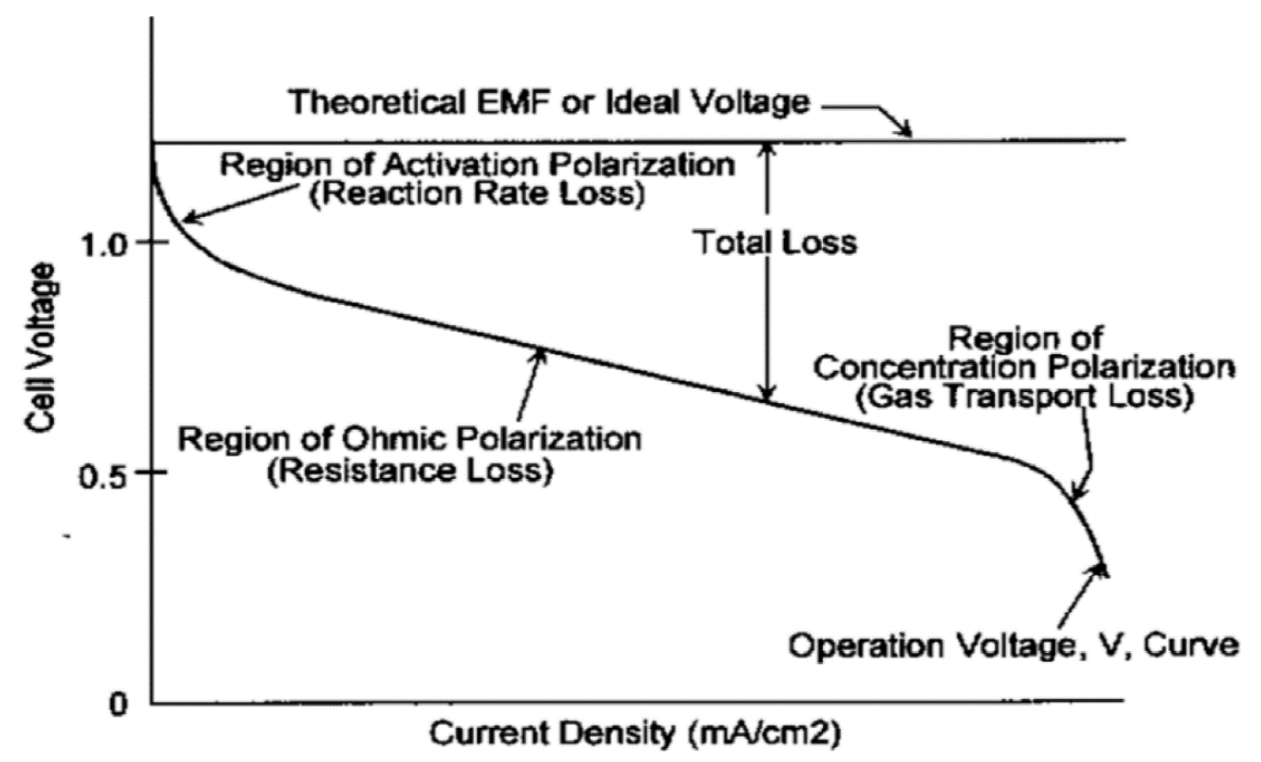

Figure 3.9 A typical voltage/current (V/I) curve of a fuel cell showing cell behavior and polarization losses [48]

Activation polarization is dominant and nonlinear at low current densities. The term is used to indicate the activation energy needed to overcome the resistance of the slowest step in the reaction. The voltage differences (or activation potential) must be overcome for the reaction to proceed. A portion of the voltage generated is lost to drive the chemical reaction forward [49].

Ohmic polarization is a linear function of the cell current. It is the voltage drop caused by the resistance of the cell to the flow of electrons and ions through the cell. Electrodes with high conductivity and thin, stable electrolytes are selected to reduce the influence of ohmic resistance. [49]

Concentration polarization dominates at high current density. It is related to the diffusion of species due to gas-phase transport. It is often referred to as a masstransport loss because the reduction of concentration is the result of a failure to 
transport sufficient reactant to the electrode surface. As the current density increases, the required flow rate of reactants to sustain the reaction also increases. Eventually, there is insufficient reactant to sustain the reaction, and the voltage drops [49].

The voltage of the cell is monitored over time at a constant current density/fuel utilization. Over time, the cell should produce a nearly constant voltage at the specified current density. These measurements give indications about the long-term stability of the cell. A decrease in the voltage over time would indicate an increase in one or more of the polarizations as a result of cell degradation.

\subsubsection{Electrochemical Impedance Spectroscopy}

Electrochemical impedance spectroscopy (EIS) is used to characterize limitations, which can be used to identify factors to improve the performance of the fuel cell [17]. With it, the different types of polarizations of the cell can be analyzed and quantified. Electrochemical impedance is usually measured by applying an AC potential with varying frequnecy to an electrochemical cell and then measuring the current through the cell. A frequency response analyzer (FRA) is used to impose the AC signal. The AC voltage and current response of the cell are analyzed by the FRA to determine the impedance (impedance is defined as the non-ideal resistance) of the cell at that particular frequency. Each polarization resistance occurs within a specific range of frequencies, so scanning over a broad frequency range allows each polarization contribution to be identified [18]

A Nyquist, or complex plane, plot shown in Figure 3.10 depicts the imaginary impedance versus the real impedance. The unique arcs and the shape of the curve provide information regarding the governing mechanism of the fuel cell behavior. The 
AC frequency dependence is implicit, so the frequency is generally listed at selected data points. The left x-axis intercept (at higher AC frequencies) indicates the contributions of the ohmic resistances $\left(R_{\Omega}\right)$. The right $\mathrm{x}$-axis intercept (at lower AC frequencies) indicates the total polarization resistances $\left(R_{\text {total }}\right)$. The distance between the two intercepts is the polarization resistance $\left(R_{p}\right)$, which is the contribution of the activation and concentration polarizations. [48, 49].

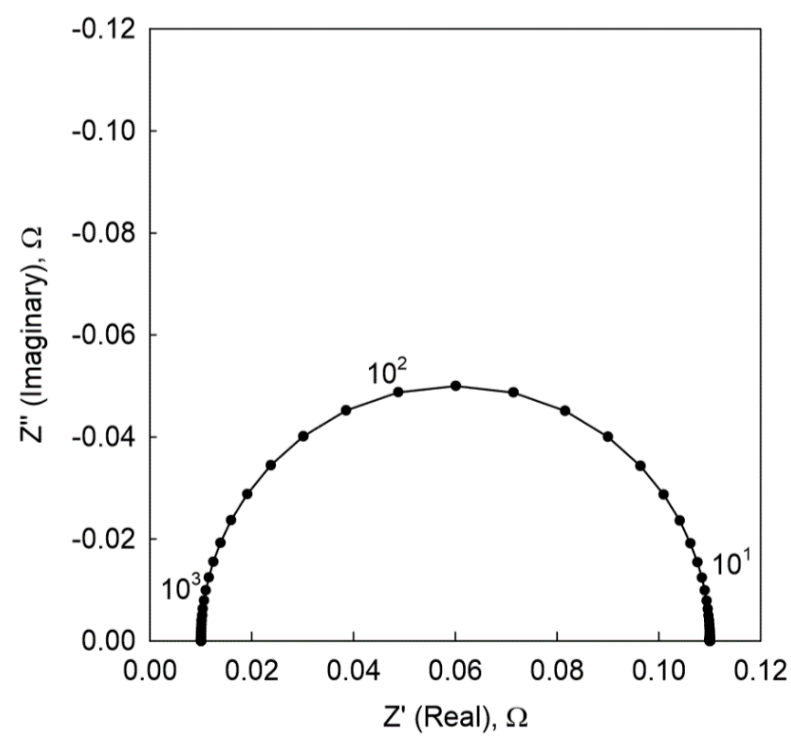

Figure 3.10 Typical representation of impedance spectroscopy using a Nyquist plot [48].

A Bode plot, shown in Figure 3.11, is typically paired with the Nyquist plot to show the impedance magnitude as a function of the frequency. The frequency scale is typically plotted on a log axis as it spans many orders of magnitude [48]. When plotted at different times, it can give information as to what specific resistances are changing over time. 


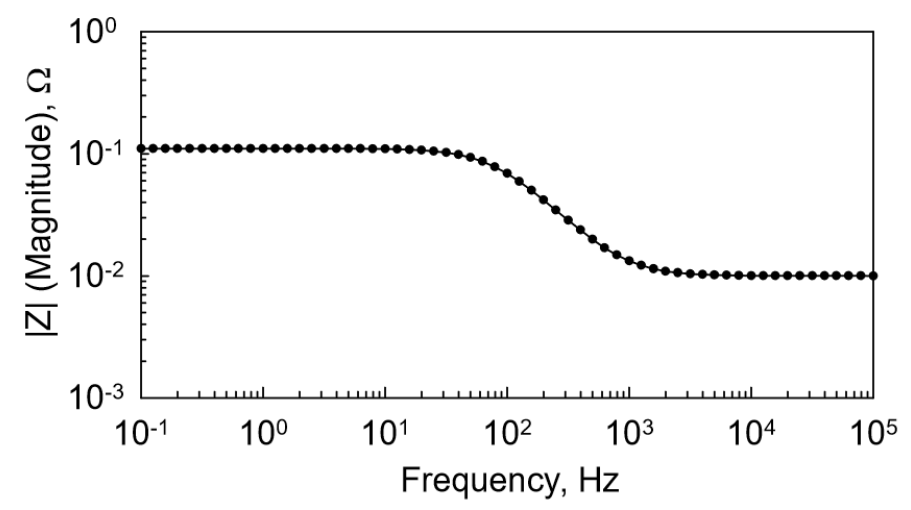

Figure 3.11 Typical bode plot representation. $Y$-axis can also be real impedance (Z') or imaginary impedance (Z').

For the present work, the cell voltage produced under a constant load is continuously monitored and logged with computer software. The cell is only removed from constant load to measure V/I curves and conduct the EIS measurements. The cell is then returned to the constant current density of $100 \mathrm{~mA} \mathrm{~cm}^{-2}$ that corresponds to a fuel utilization of $12.5 \%$ for the fuel cell used in this project.

\subsubsection{Cell Characterization}

The procedure for the material characterization of the fuel cells was established. This includes the use of the PANalytical X'Pert Pro X-ray Diffractometer (XRD), the Physical Electronics PHI 5000 VersaProbe X-Ray Photoelectron Spectroscopy (XPS), and the Hitachi S-4700F Scanning Electron Microscope (SEM), all provided by the Shared Research Facilities (SRF) of WVU. Training for use of the equipment is provided by the SRF staff, but the procedure for the preparation of the samples needed to be developed.

Upon shutdown of the fuel cell testing system, it was desired to limit the exposure of the fuel cell to the environment until it could be fully analyzed. The cell was carefully 
removed from the manifolds and placed in a vacuum bag. After the vacuum bag was sealed, it was placed inside a glovebox containing a nitrogen atmosphere. This ensured no interaction with the ambient environment.

Once the cell is in the glovebox, great care is taken to ensure minimal exposure with the ambient environment, specifically oxygen in the air. Six samples are prepared from each fuel cell in the glovebox to minimize their exposure to air. The sample locations shown in Figure 3.12 were chosen to maximize resources. These sample locations are specific reference points and are used for naming purposes, such as P1, P2, etc. These locations will allow for the determination of any gradients present on the anode surface as a result of cell operation and/or $\mathrm{PH}_{3}$ poisoning.

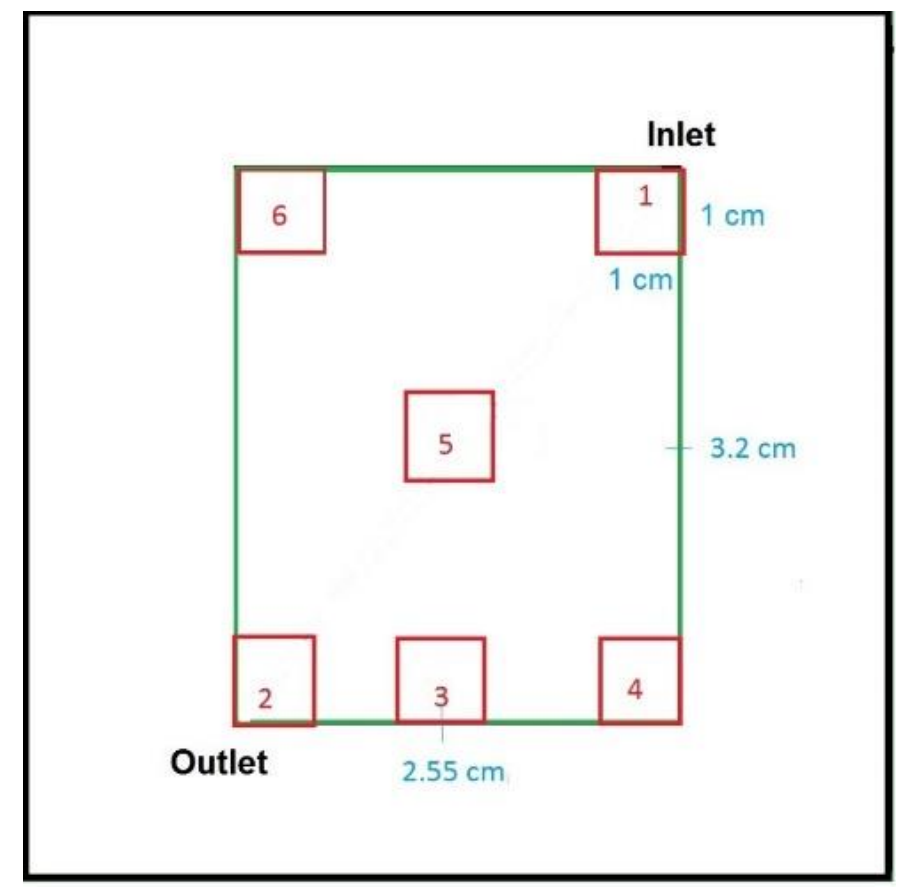

Figure 3.12 Specific positions of sample locations taken from each SOFC after testing. 
The SEM and XPS operate in vacuum, so it will be a simple process to mount the samples to their respective holders and transfer them to the equipment while minimizing their exposure to air. The XRD does not operate under vacuum, so a different procedure needed to be developed for it.

For the XRD, the sample holders were introduced into the glovebox. The samples were then mounted to the holder. Vacuum grease was applied to the edges and a mylar film was used to seal the sample. This limits the exposure to the ambient environment. Mylar film does not interfere with the x-rays of the XRD. The order of analysis is XRD, XPS, and finally SEM.

\subsubsection{Safety Concerns}

All experiments were conducted in the large walk-in fume hoods in Room 317 of the Engineering Research Building (ERB). There are safety concerns with any experiment. For this project, some of the concerns are the high flammability of hydrogen, the high toxicity of phosphine, and the high operating temperature of the furnace. All experiments were designed to limit the exposure to the operator and the dangers associated with the processes. The testing set up was inspected and approved by the West Virginia University Environmental Health and Safety Department (EHS). All safety data sheets (SDS) and laboratory procedures are maintained electronically and in a binder in the laboratory. 


\section{Chapter 4: Results and Discussion}

In this chapter, the results from the various tests on the planar SOFC are presented. In the first section, the details of the performance testing of the SOFC operation with hydrogen are presented. The second section presents the performance results of the preliminary test with $10 \mathrm{ppm}$ of $\mathrm{PH}_{3}$. The third section details the more rigorous test with $10 \mathrm{ppm}$ of $\mathrm{PH}_{3}$. The final section presents the material characterization of the various cells before and after testing using XRD, XPS, and SEM.

\subsection{SOFC Operation with Hydrogen}

Multiple fuel cells were operated at $800^{\circ} \mathrm{C}$ with pure hydrogen at $200 \mathrm{SCCM}$ to establish the testing methodology and demonstrate the required stability over the desired operation time. Air was used at 300 SCCM at the cathode. When not collecting polarization curves and impedance spectra, cells were loaded to a constant value of $100 \mathrm{~mA} \mathrm{~cm}^{-2}$, (the absolute current flow was $3.3 \mathrm{~A}$ ), corresponding to a fuel utilization of $12.5 \%$. The oxygen utilization was $18 \%$.

Of the cells that maintained operation over 150 hours, there was a significant amount of time required to reach stable performance. This is henceforth referred to as "burn-in" and can take hours or days to complete. It is typically attributed with the improvement of cathode kinetics after initial polarization when the cathode material is LSM or a similar material [51], [52], and [53]. In Figure 4.1, the burn-in time is shown to be around 200 hours for the cells that were tested for 500 hours. 


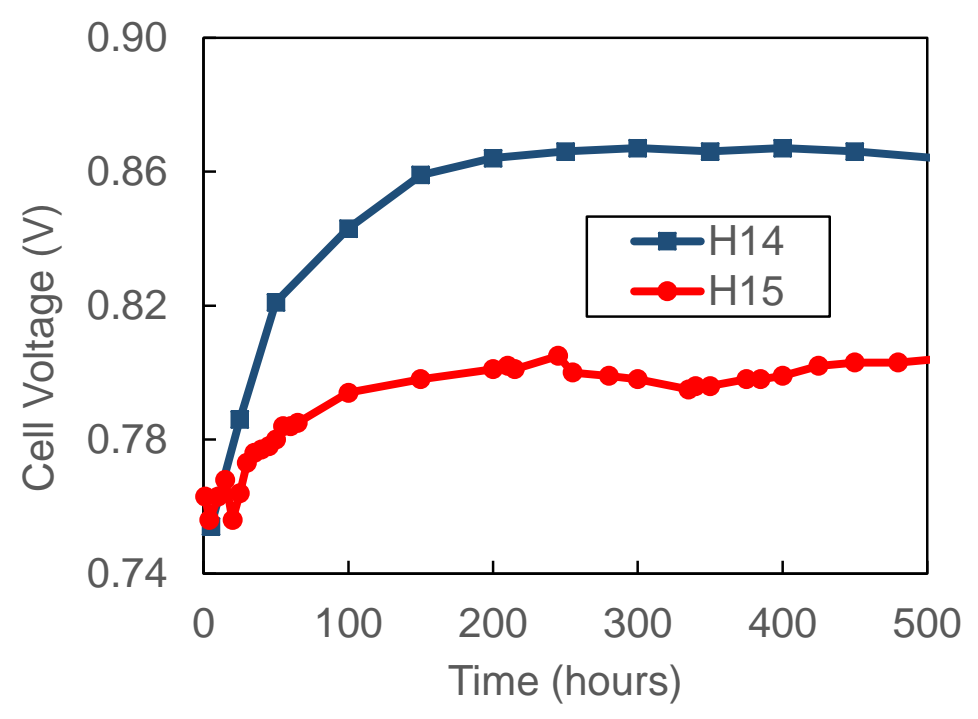

Figure 4.1 Standard baseline performance of cells operated in hydrogen gas operated at a current density of $100 \mathrm{~mA} \mathrm{~cm}^{-2}$. Degradation rates were calculated to the order of microvolts and considered negligible.

After the 200 hour burn-in period, degradation rates for each cell were calculated to the order of microvolts and were considered negligible for two separate tests $\left(1 \times 10^{-7}\right.$ and $3 \times 10^{-6} \mathrm{~V} \mathrm{hr}^{-1}$ for $\mathrm{H} 14$ and $\mathrm{H} 15$, respectively). The peak voltages when loaded to 100 $\mathrm{mA} \mathrm{cm}{ }^{-2}$ were $0.867 \mathrm{~V}$ and $0.805 \mathrm{~V}$ for $\mathrm{H} 14$ and $\mathrm{H} 15$, respectively. This $7.1 \%$ difference is attributable to slight differences in the microstructure of each fuel cell's electrodes and differences in the electrical conductivity between the fuel cell electrodes and the manifolds due to the nature of assembly. The fluctuations observed for the $\mathrm{H} 15$ fuel cell are attributable to non-ideal electrical conductivity between the electrodes and the manifold.

The polarization and power density curves as seen in Figure 4.2 show the increase in cell performance that occurred after burn-in. Open-cell voltage (OCV) for $\mathrm{H} 14$ and $\mathrm{H} 15$ were $1.130 \mathrm{~V}$ and $1.083 \mathrm{~V}$, respectively. Current was increased step-wise 
by $0.1 \mathrm{~A}$ until the cell voltage fell to $0.2 \mathrm{~V}$ and then it was stopped. This was done to prevent irreversible damage to the cell from operating at excessively high current.

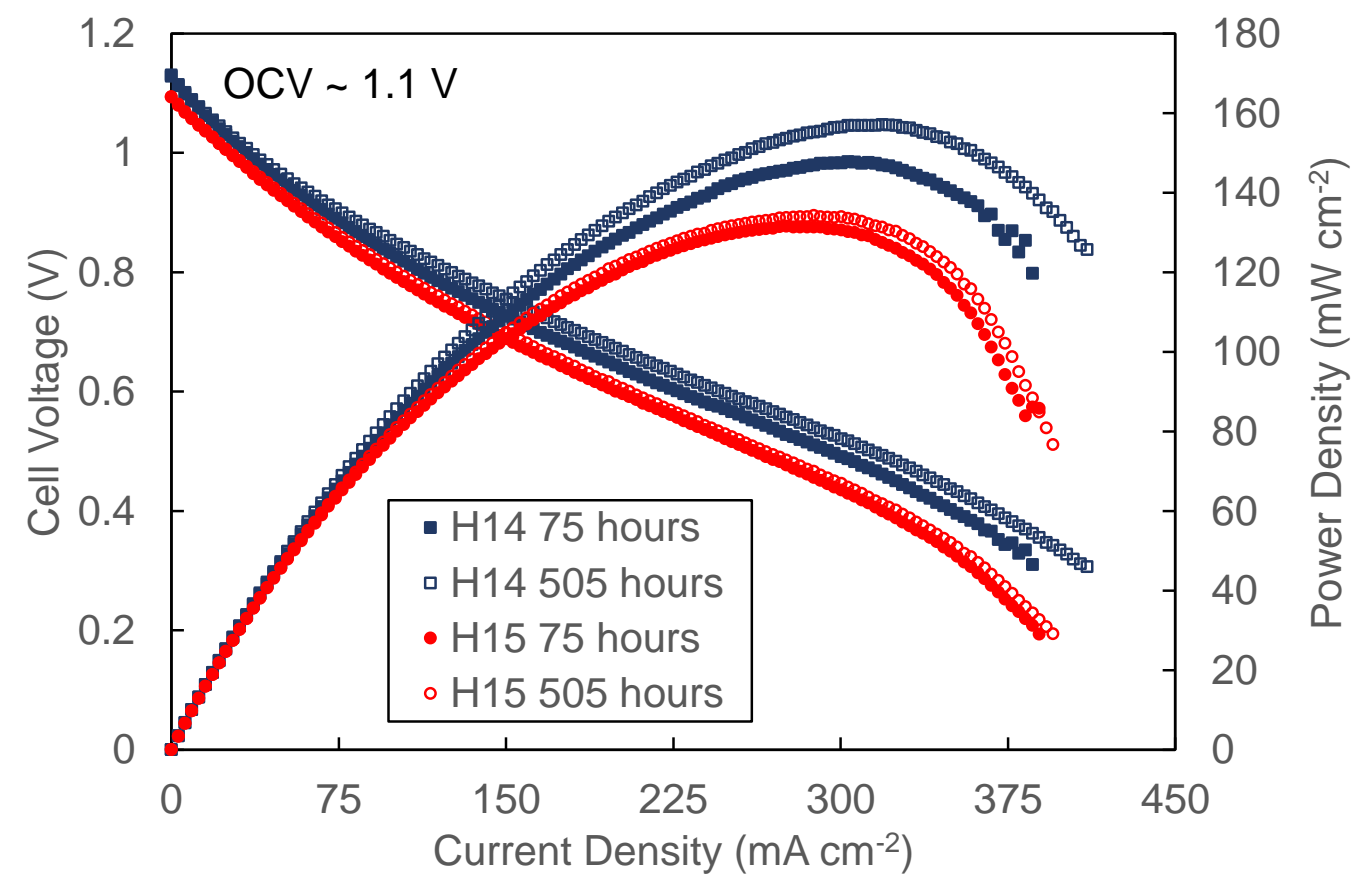

Figure 4.2 Cell performance before ( 75 hours) and well after (505 hours) burn-in has been completed. Arrows point towards the respective axis for each set of curves.

Peak power density for the $\mathrm{H} 14$ and $\mathrm{H} 15$ cells were approximately $157 \mathrm{~mW} \mathrm{~cm}^{-2}$ and $134 \mathrm{~mW} \mathrm{~cm}^{-2}$, respectively. The $\mathrm{H} 14$ fuel cell exhibited a peak power density $14.6 \%$ higher than the $\mathrm{H} 15$ fuel cell. This would indicate that the $\mathrm{H} 15$ cell has greater polarization losses (larger resistances) than the $\mathrm{H} 14$ cell. This difference was further investigated through the analysis of the impedance data. 
The impedance spectra at OCV as shown in Figure 4.3 were similar over the entire life of the tests. The left, or high-frequency, intercept (at $4000 \mathrm{~Hz}$ here) is the ohmic resistance $\left(R_{\Omega}\right)$. For the $\mathrm{H} 14$ cell, $R_{\Omega}$ increases from 0.51 to $0.58 \Omega \mathrm{cm}^{2}$ over the length of the test. For the $\mathrm{H} 15$ cell, $R_{\Omega}$ increases from 0.59 to $0.63 \Omega \mathrm{cm}^{2}$ over the length of the test. The larger $R_{\Omega}$ of the $\mathrm{H} 15$ cell contributes to the lower power density than the $\mathrm{H} 14$ cell. The low-frequency intercept (near $4 \mathrm{~Hz}$ here) is the value of the total polarization resistances ( $R_{\text {total }}$. The $R_{\text {total }}$ for both fuel cells would appear to be near 1.5 $\Omega \mathrm{cm}^{2}$, however the plots do not cross the axis at low frequencies.

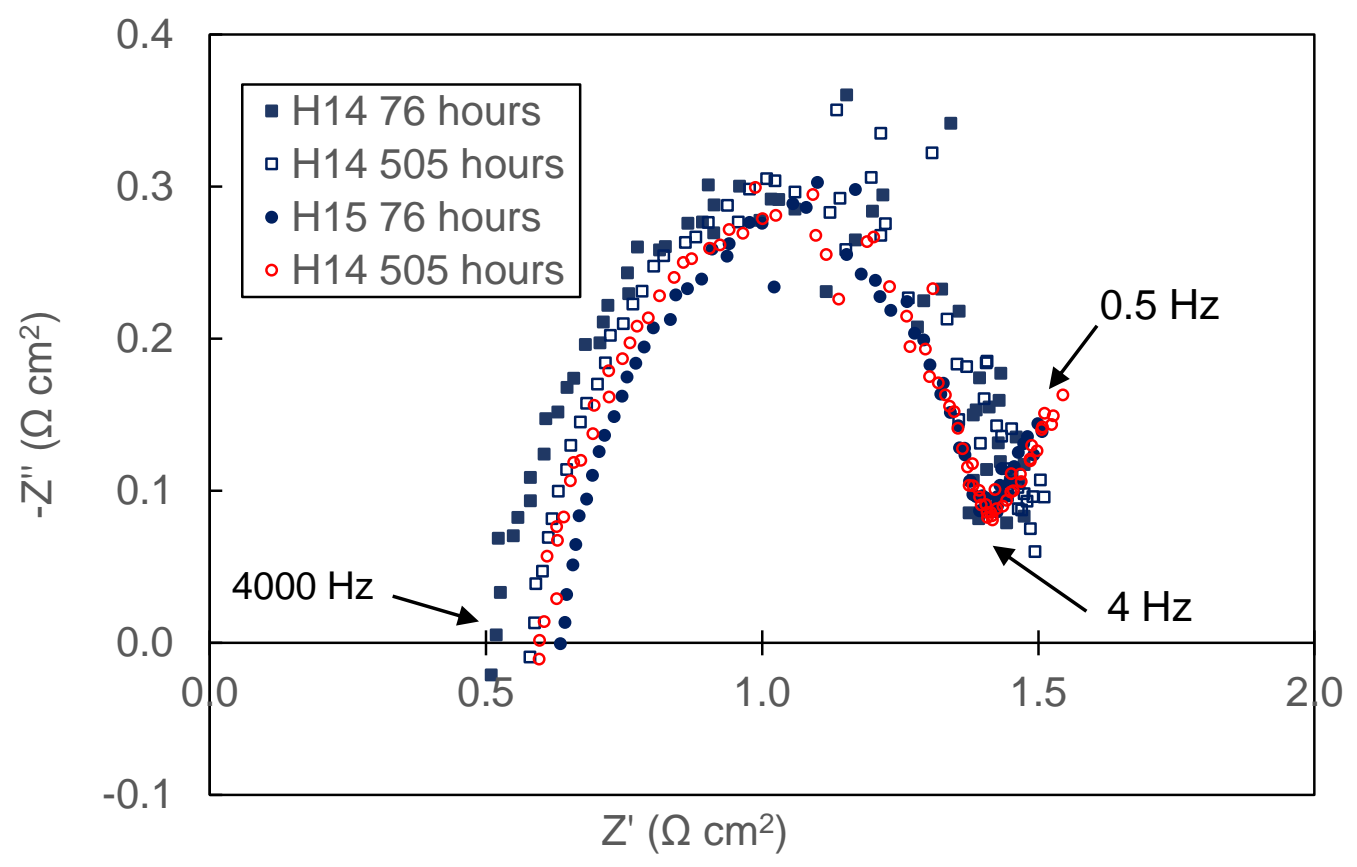

Figure 4.3 Nyquist plots for cells at OCV. The left intercept occurs at 3000 $\mathrm{Hz}$ and the right intercept would be below $4 \mathrm{~Hz}$

The impedance spectra at a bias current of $1.0 \mathrm{~A}$ are shown in Figure 4.4. Again, the data were similar between both tests. $R_{\Omega}$ is $0.75 \Omega \mathrm{cm}^{2}$ for $\mathrm{H} 14$ and $0.82 \Omega \mathrm{cm}^{2}$ for $\mathrm{H} 15$. The total polarization resistances for both would appear to be over $2.0 \Omega \mathrm{cm}^{2}$, however the plots again do not cross the axis at lower frequencies. An interesting 
similarity of not applying a bias current (keeping at OCV) versus applying a bias current is that there was no observed increased of $R_{\Omega}$. There is no standardized reporting for impedance data to use a bias current or not.

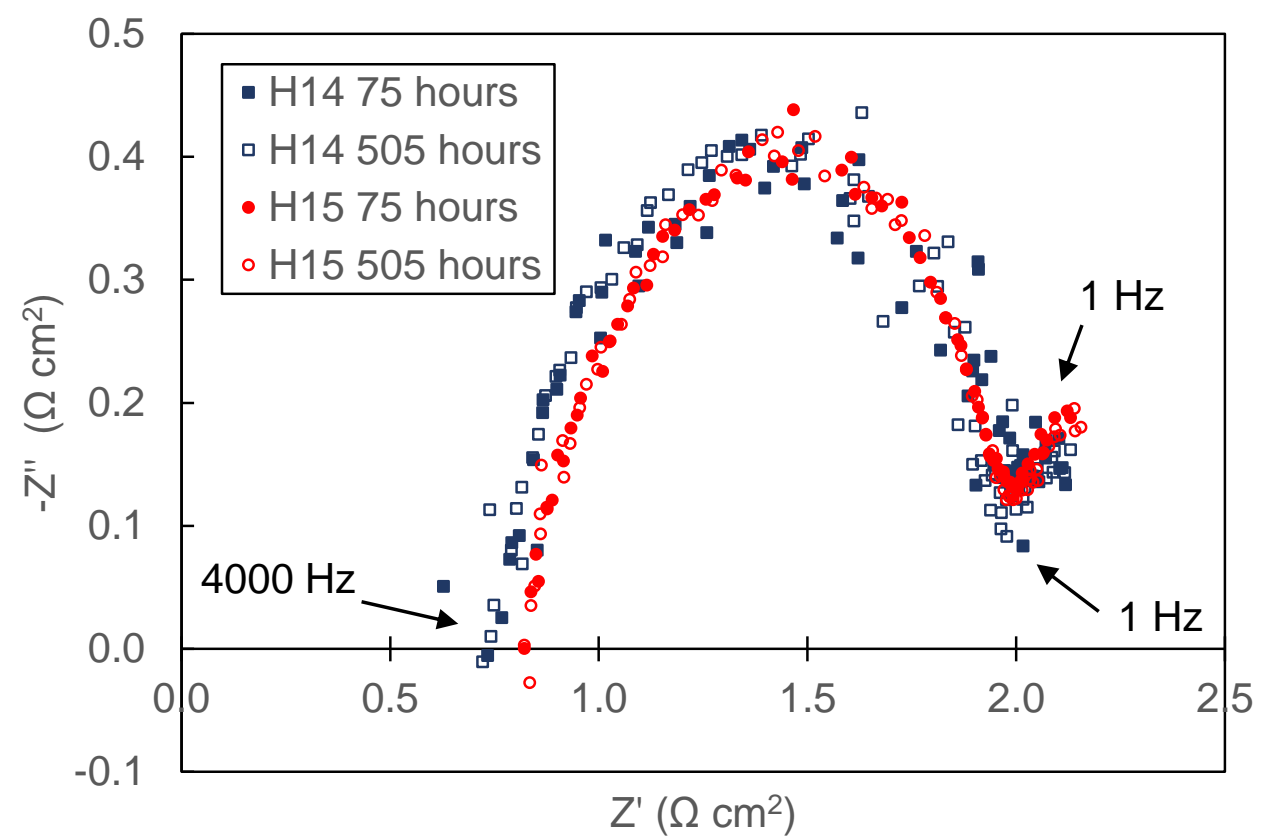

Figure 4.4 Nyquist plots for cells loaded at 1.0 A. The left intercept occurs at $4000 \mathrm{~Hz}$ and the right intercept would be near $0.1 \mathrm{~Hz}$.

There are some differences when gathering impedance data at open cell voltage $(\mathrm{OCV})$ and when a bias current is applied. Figure 4.5 illustrates these changes. $R_{\Omega}$ shifts to the right as the current is increased due to the temperature of the cell increasing with increasing current load. The $R_{\text {total }}$ and the distance between the two intercepts, $R_{p}$, also increases as the bias current is increased. The values of the polarizations change, but still occur over the same frequency range of the sweep. 


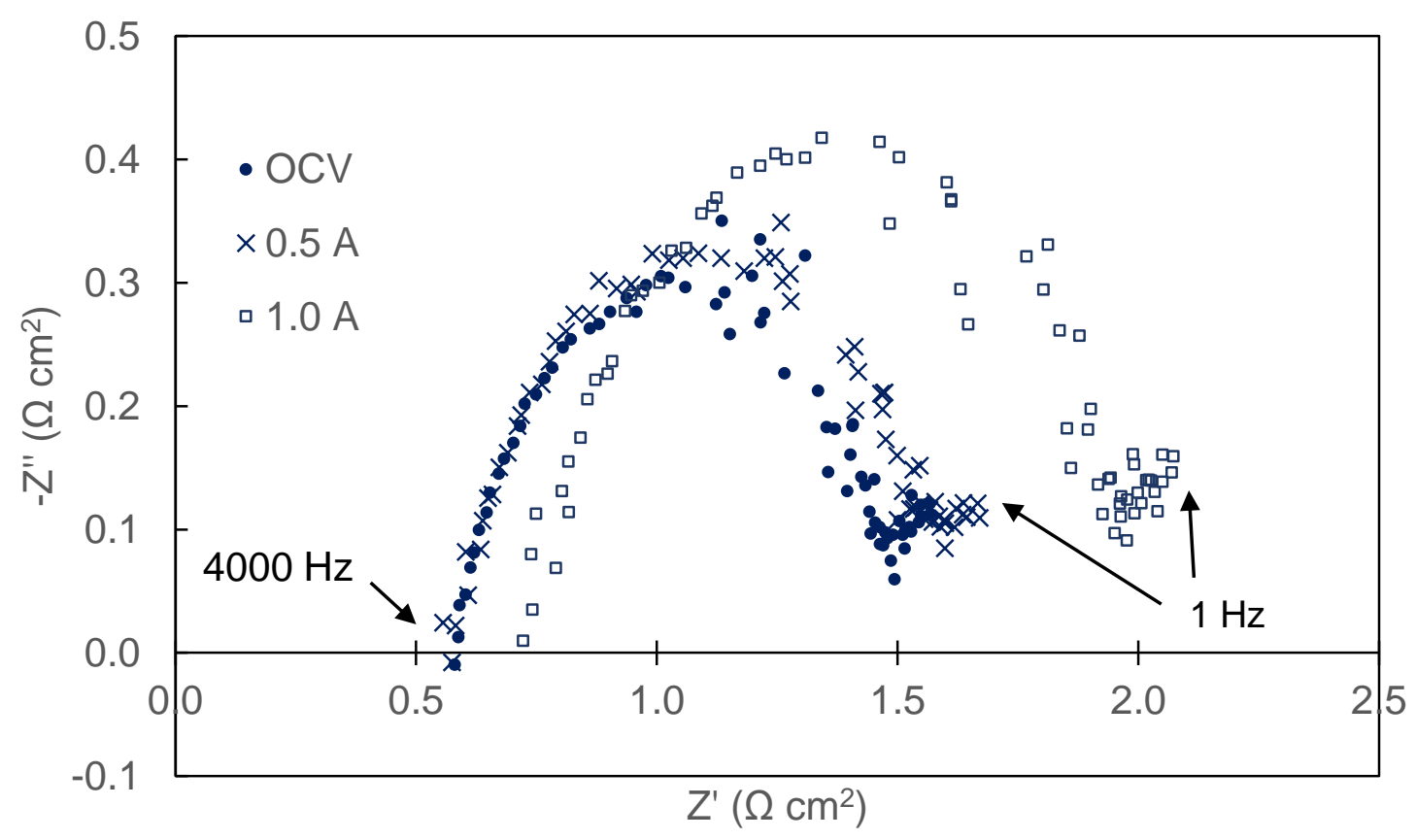

Figure 4.5 Nyquist plots at OCV, 0.5 A, and $1.0 \mathrm{~A}$ for H14 cell after 505 hours of operation.

The Bode plot in Figure 4.6 shows the impedance changing over the first 200 hours. The resistance in the range of $10-100 \mathrm{~Hz}$, associated with the cathode charge transfer reaction [54], decreases and becomes constant after 200 hours. This makes sense, as [51], [52], and [53] associated burn-in with an increased rate of the cathode reaction kinetics. Increasing the rate of the cathode reaction would decrease the associated impedance value. The impedance in the region of $150-10,000 \mathrm{~Hz}$, associated with the anode charge transfer reaction [54], increases to its maximum over the first 100 hours, then decreases to a constant value over the next 100 hours. 


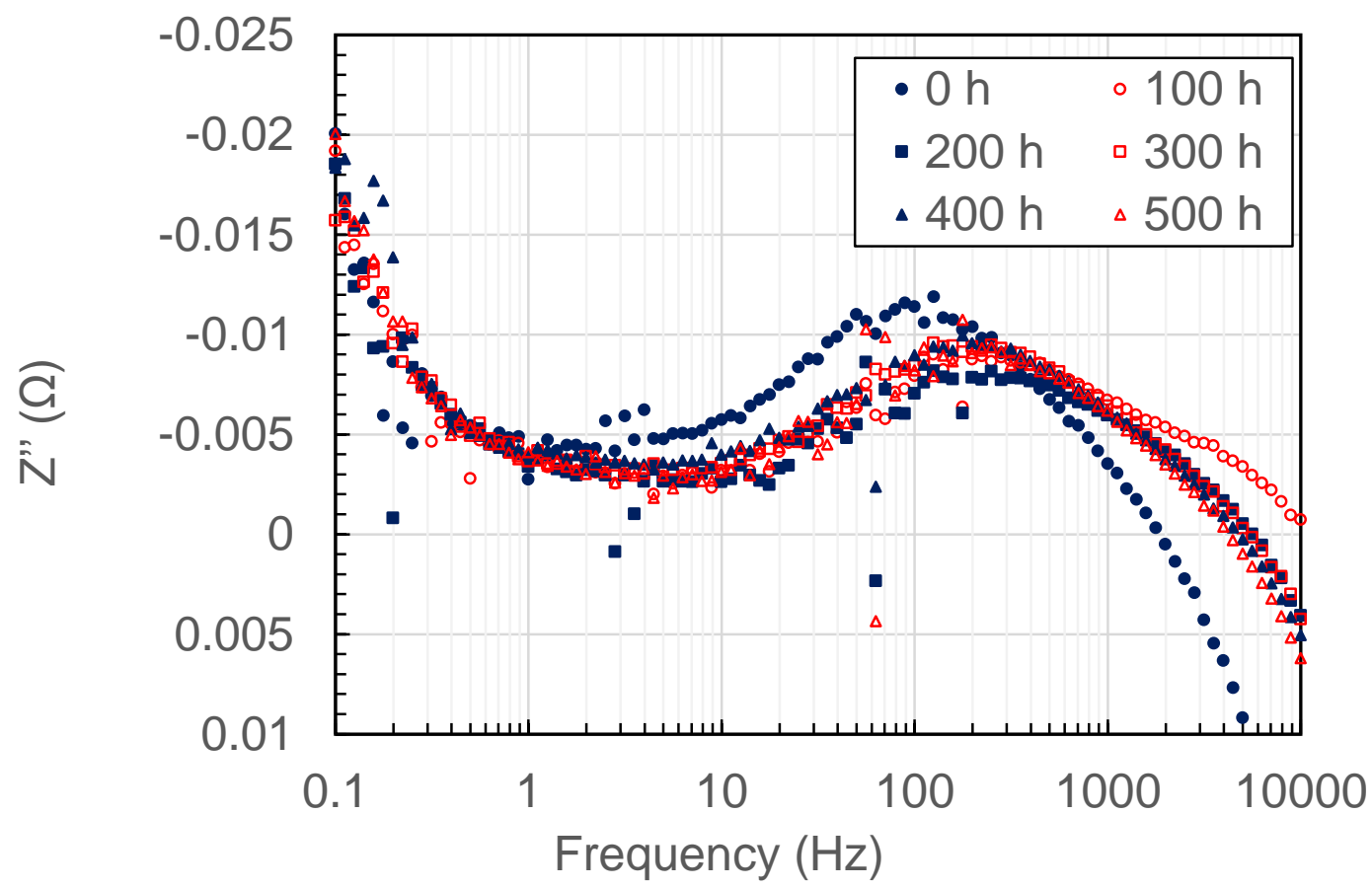

Figure 4.6 Bode plot for baseline $\mathrm{H}_{2}$ cell at OCV (no bias current). Resistances decrease as the anode reduction is completed after the burn-in period. 


\subsection{SOFC Operation in Phosphine - Preliminary Trial}

A preliminary trial with phosphine was conducted using the same parameters as the baseline hydrogen testing. The temperature of operation was $800^{\circ} \mathrm{C}, 200 \mathrm{SCCM}$ of pure $\mathrm{H}_{2}$ to the anode, $300 \mathrm{SCCM}$ air to the cathode. The pure $\mathrm{H}_{2}$ was switched to 10 ppm $\mathrm{PH}_{3}$ in $\mathrm{H}_{2}$ after a period of only 24 hours. This was a preliminary test because 24 hour was not a full burn-in period. It provided valuable information for the next test using $\mathrm{PH}_{3}$. When not collecting polarization curves and impedance spectroscopy, cells were again loaded to $100 \mathrm{~mA} \mathrm{~cm}^{-2}$ (the absolute current flow was $3.3 \mathrm{~A}$ ), corresponding to a fuel utilization of $12.5 \%$.

At a constant load of $100 \mathrm{~mA} \cdot \mathrm{cm}^{-2}$, the average cell degradation rate from Figure 4.7 was constant at $0.026 \mathrm{mV} \mathrm{h}^{-1}$ over the 500 hours of the test, which is considerably lower than published data described in Section 2.4. The degradation rate from Xu et al. [20] was reported as $0.46 \mathrm{mV} \mathrm{h}^{-1}$, Chen et al. [21] $0.7 \mathrm{mV} \mathrm{h}^{-1}$, and Li et al. [22] $1.68 \mathrm{mV}$ $\mathrm{h}^{-1}$. All three of these studies used anode-supported fuel cells, which have significantly thicker Ni-anodes than the electrolyte cells used in this study. These are all at least an order of magnitude higher than the degradation rate seen in the cell tested here. It would be expected that the degradation of the thinner anode of the electrolytesupported fuel cell would be accelerated. The cell maintained OCV near $1.148 \mathrm{~V}$ during the entire trial (when the cell was temporarily removed from constant load to complete I$V$ and EIS testing). 


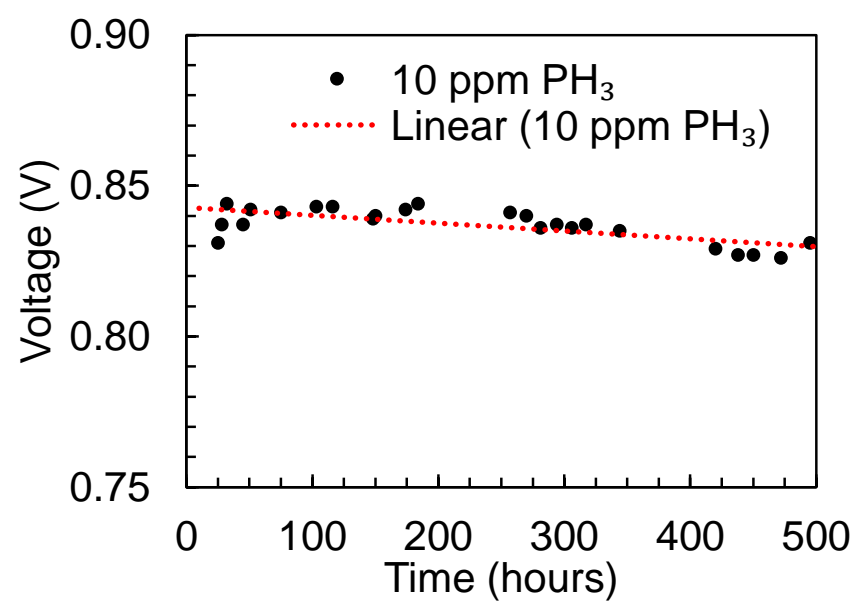

Figure 4.7: Cell voltage over time at $100 \mathrm{~mA} \mathrm{~cm}^{-2}$ with $10 \mathrm{ppm}$ phosphine in $\mathrm{H}_{2}$ (voltages after Hour 93 are corrected due to one of the voltage taps breaking). Degradation rate was $0.026 \mathrm{mV} \cdot h^{-1}$

Phosphine was introduced at Hour 23. Evaluation of the cells that operated with only pure $\mathrm{H}_{2}$ showed that this was not the full "burn-in" period. At Hour 116, one of the platinum thin-wire voltage taps broke from the cell. This reduced the measurements from a 4-point to a 2-point configuration. As a consequence, impedance measurements could no longer be taken. The voltage measurement lead from the broken voltage tap was moved to the end of the manifold. This added an extra resistance to the line and decreased the voltage readings. Thus, the readings after Hour 116 in Figure 4.7, and subsequent Figures, were corrected to account for the known and constant ohmic resistance of the manifold.

As seen from the polarization and power curves of Figure 4.8, current was increased step-wise by $0.1 \mathrm{~A}$ until the cell voltage fell to $0.2 \mathrm{~V}$. This was done to prevent irreversible damage to the cell from excessive current. The readings from Hour 116 and later were corrected, due to the previously mentioned wire break. The curves stop at $340 \mathrm{~mA} \mathrm{~cm}^{-2}$ because current loading was still stopped when the pre-corrected voltage 
reading reached $0.2 \mathrm{~V}$. The cell was operated with $10 \mathrm{ppm} \mathrm{PH}_{3}$ in $\mathrm{H}_{2}$ for 450 hours. The current and power densities of the fuel cell decreased slowly over the duration of the test. The fuel was switched to pure $\mathrm{H}_{2}$ for a period of 24 hours after operating with $\mathrm{PH}_{3}$ to determine if there would be any increase in performance resulting from a reversal of the degradation from phosphine. Measurements were taken for an additional 24 hours (Hour 496) and the power density increased by almost $8 \%$ at the end of that 24 hours.

This suggests that any degradative effect caused by phosphine was not irreversible.

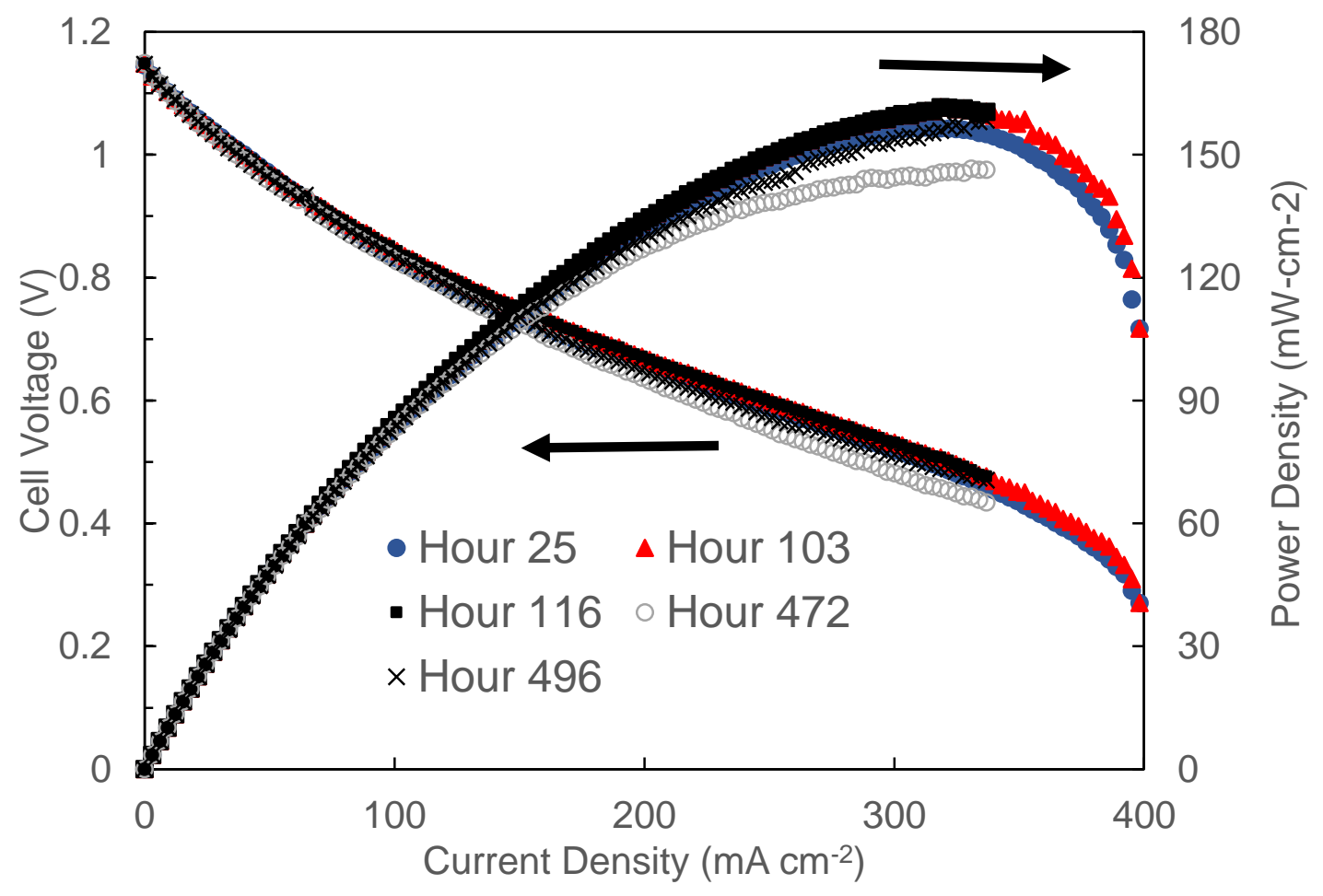

Figure 4.8 Hour 25 was the second hour of phosphine exposure. Hour 116 was the first measurement from the new measuring point on the manifold. Hour 472 was the last measurement with phosphine. Hour 496 was pure hydrogen. 
The last impedance measurement was taken at Hour 93. The impedance spectra shown in Figure 4.9 at 1.0 A bias current fluctuated some, but did not show the resistance increasing or decreasing over time. $R_{\Omega}$ is near $0.65 \Omega \mathrm{cm}^{2}$ for the first 93 hours. There are indications of diffusion limitations within the low frequency portion of the plot, as the curve does not cross the axis at low frequency. $R_{\text {total }}$ would appear to be $1.8 \Omega \mathrm{cm}^{2}$ if the curve were to be projected across the axis.

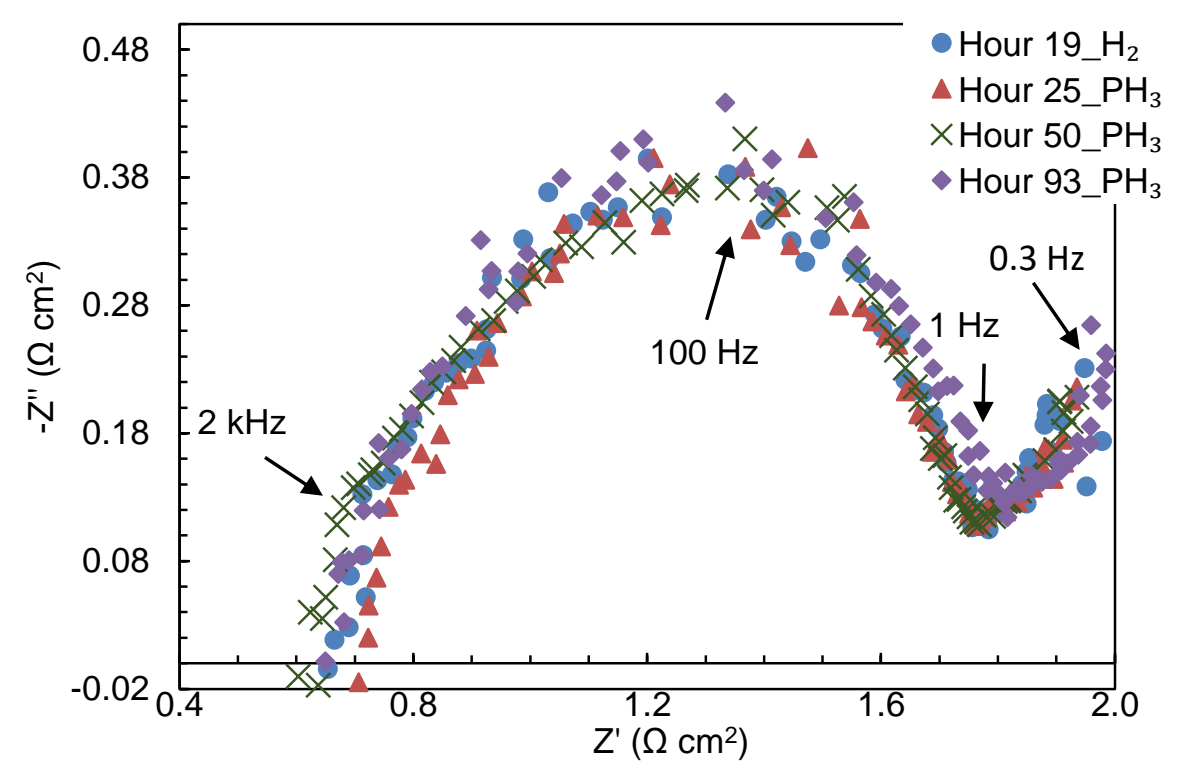

Figure 4.9: Nyquist plot of impedance spectrum before and after exposure to $10 \mathrm{ppm} \mathrm{PH}_{3}$, until voltage/current taps broke. 


\subsection{SOFC Operation in Phosphine - Second Trial}

The second trial with phosphine was conducted using the same parameters as the baseline hydrogen testing. The temperature of operation was $800^{\circ} \mathrm{C}, 200 \mathrm{SCCM}$ of pure $\mathrm{H}_{2}$ to the anode, 300 SCCM air to cathode. Unlike the first trial, the key to the second trial was that the fuel cell was allowed to complete a full burn-in period before the introduction of $10 \mathrm{ppm}$ of $\mathrm{PH}_{3}$ in $\mathrm{H}_{2}$. Burn-in was completed after approximately 190 hours and the phosphine was introduced, as seen in Figure 4.10.

No irreversible degradation was observed after the introduction of the $10 \mathrm{ppm}$ $\mathrm{PH}_{3}$ in $\mathrm{H}_{2}$. Figure 4.10 shows a drop of almost $0.01 \mathrm{~V}$ over the first 10 hours that the fuel cell was exposed to $\mathrm{PH}_{3}$. However, after this initial drop, the voltage is nearly constant at $0.84 \mathrm{~V}$ when loaded to a constant value of $100 \mathrm{~mA} \mathrm{~cm}^{-2}$ during the duration of the test with $\mathrm{PH}_{3}$. The cell operated for 450 hours in $\mathrm{PH}_{3}$ at an average degradation rate of only $3 \times 10^{-6} \mathrm{~V} \mathrm{~h}^{-1}$, which is comparable to the baseline $\mathrm{H}_{2}$ tests (pictured baseline $\mathrm{H}_{2}$ degradation rate is $1 \times 10^{-7} \mathrm{~V} \mathrm{~h}^{-1}$ ), and 4 orders of magnitude smaller than the preliminary $\mathrm{PH}_{3}$ test.

The fuel was switched to pure $\mathrm{H}_{2}$ for a period of 50 hours after operating with 10 ppm $\mathrm{PH}_{3}$ in $\mathrm{H}_{2}$ to determine if there would be any increase in performance resulting from a reversal of any degradation from phosphine. Performance decreased from 0.840 $\mathrm{V}$ to $0.835 \mathrm{~V}$ immediately after switching back to pure $\mathrm{H}_{2}$ fuel, but recovered back to $0.840 \mathrm{~V}$ after 20 hours of operation with pure $\mathrm{H}_{2}$ fuel. Performance peaked to $0.844 \mathrm{~V}$ after 40 hours with the pure $\mathrm{H}_{2}$ fuel, then settled back to $0.840 \mathrm{~V}$ at the end of the 50 hour period. 


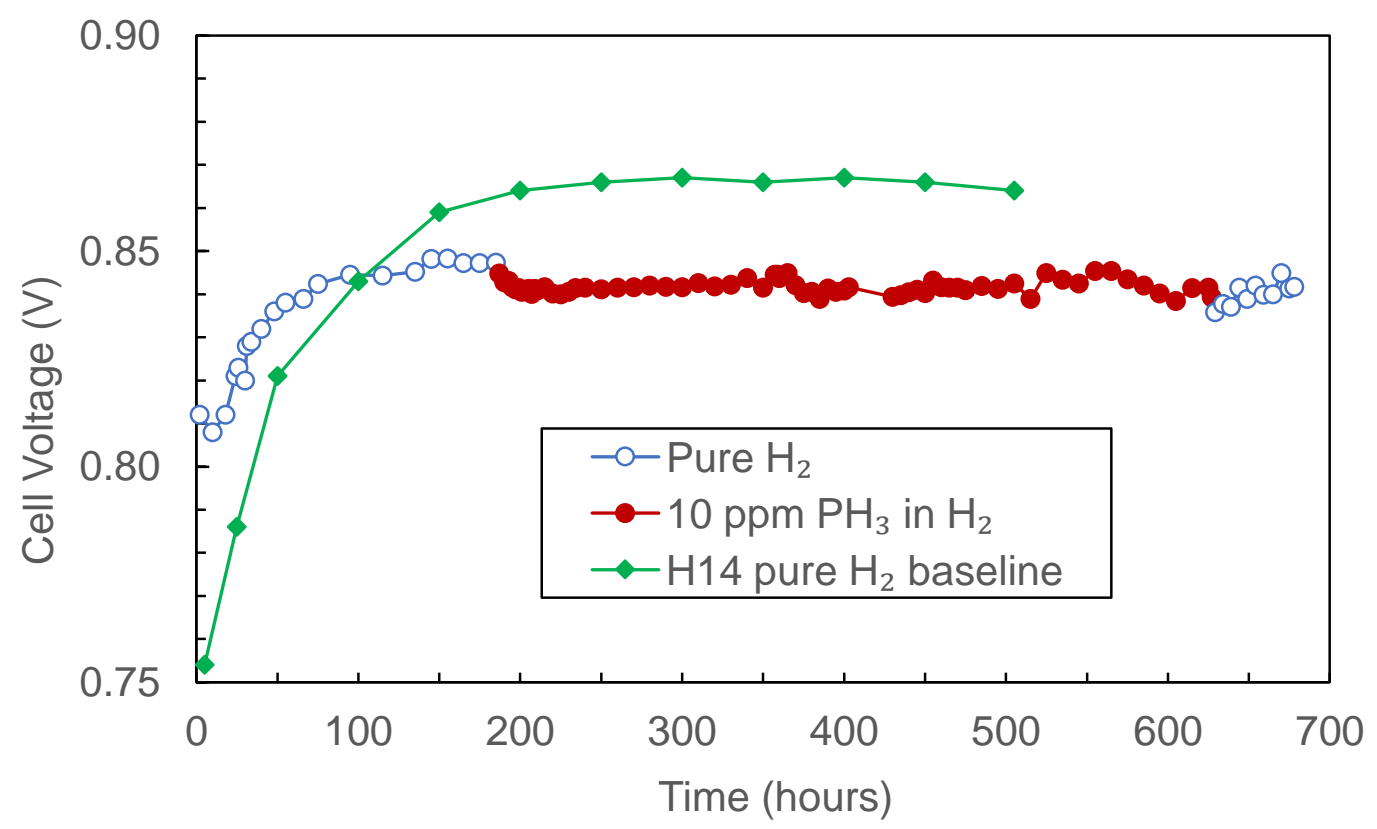

Figure 4.10 Cell voltage over time at $100 \mathrm{~mA} \mathrm{~cm}^{-2}$ with $10 \mathrm{ppm}$ phosphine. Degradation rate after introduction of $\mathrm{PH}_{3}$ is $3 \times 10^{-6} \mathrm{~V} \mathrm{hr}^{-1}$.

$\mathrm{PH}_{3}$ was introduced after 187 hours of operation. After approximately 170 hours of operation in $\mathrm{PH}_{3}$ (360 hours total), a thin-wire platinum voltage tap wire was again broken. This reduced the measurements from a 4-point to a 2-point configuration and hence impedance measurements could no longer be taken. The voltage measurement lead from the broken voltage tap was moved to the end of the manifold. This added an extra resistance to the line and decreased the voltage readings. Thus, the readings after Hour 170 (in $\mathrm{PH}_{3}$, almost 360 hours of total operating time) were corrected to account for the known and constant ohmic resistance of the manifolds.

. There was a sampling port to measure the inlet concentration of the phosphine by means of a photoionization detector (RAE Systems, MultiRAE Plus) before it reached the fuel cell. This detector was also moved to the exhaust line from the anode to measure the $\mathrm{PH}_{3}$ concentration exiting the anode. From Figure 4.11, the inlet 
concentration was near the expected value of $10 \mathrm{ppm}$ when the $\mathrm{PH}_{3}$ in $\mathrm{H}_{2}$ was started. The exhaust concentration was initially lower than the inlet concentration. After a certain amount of time, the detector lost its sensitivity to the $\mathrm{PH}_{3}$.

It is noted that the $\mathrm{PH}_{3}$ can coat the UV lamp of the photoionization detector [47], [55]. This could lead to inaccurate readings. It was also observed that water vapor condensing near the detector's inlet pump would cause a spike in the readings. However, the goal of using the detector was not to give an accurate measurement of the $\mathrm{PH}_{3}$ in the exhaust. The goal was to trace the path of $\mathrm{PH}_{3}$ through the system. The detector did indeed confirm that $\mathrm{PH}_{3}$ was traveling to the anode and then exiting through the exhaust.

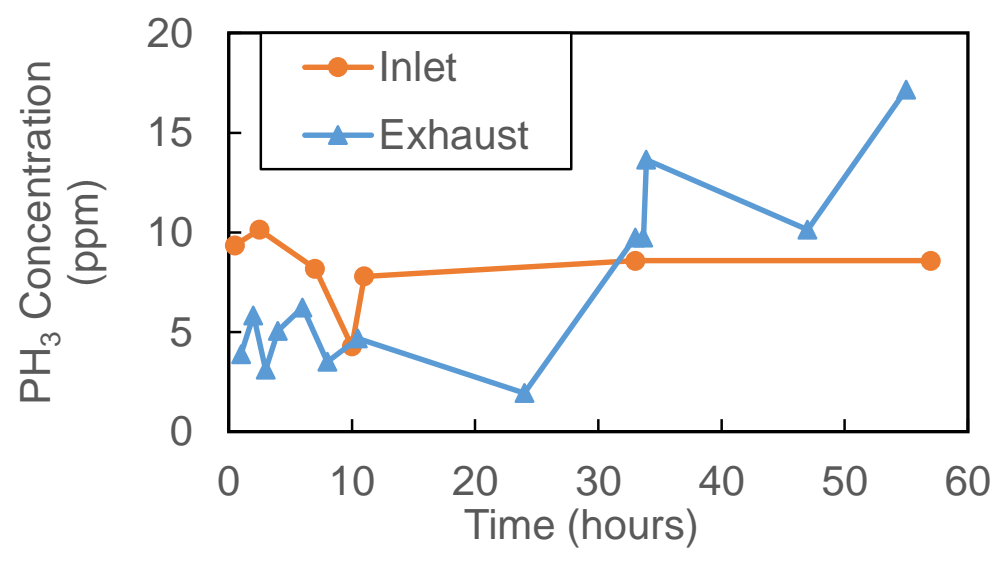

Figure $4.11 \mathrm{PH}_{3}$ concentration measurements measured at the sampling port before the inlet of the anode manifold and again at the exhaust of the anode manifold.

Figure 4.12 shows the polarization (I-V) curves during operation with $\mathrm{PH}_{3}$. OCV was maintained at $1.122 \mathrm{~V}$ during operation and there were no other signs of degradation due to $\mathrm{PH}_{3}$ poisoning. If the anode were being reconstructed, the curves should have been shifting downward, as the cell would not be able to maintain 
performance. The degradation rate for this test was $3 \times 10^{-6} \mathrm{~V} \mathrm{~h}-1$, which is comparable to the pure $\mathrm{H}_{2}$ degradation rate of $1 \times 10^{-7} \mathrm{~V} \mathrm{~h}^{-1}$. The minor shift downward is most likely due to the electrical contact between components degrading as seen earlier with the pure $\mathrm{H}_{2}$ tests.

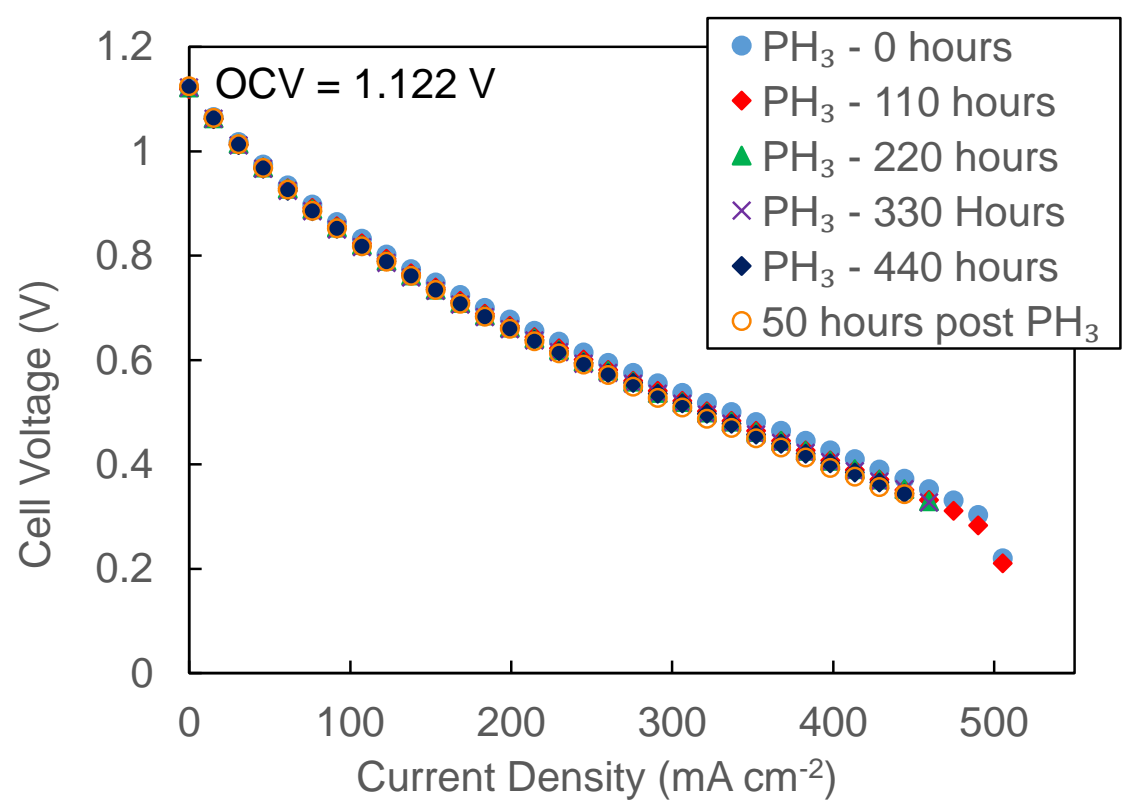

Figure 4.12 "PH3 - 0 Hour" is the measurement taken initially when the $\mathrm{PH}_{3}$ contaminated fuel was introduced. The curves do not shift downward. "50 Hours after PH3" is the measurement taken after the cell had been allowed to run for 50 hours after $\mathrm{PH}_{3}$ exposure.

Figure 4.13 shows that the power density changed over the course of the test.

The power density decreases by $4.1 \%$ from the peak of $170 \mathrm{~mW} \mathrm{~cm}^{-2}$ over the first 110 hours of operation with $\mathrm{PH}_{3}$. However, the value does not decrease significantly during operation over the 450 hours of $\mathrm{PH}_{3}$ exposure. The power density decreases by only $1 \%$ from 110 hours to 440 hours (from $163 \mathrm{~mW} \mathrm{~cm}^{-2}$ to $161 \mathrm{~mW} \mathrm{~cm}{ }^{-2}$ ). It is not likely that the $\mathrm{PH}_{3}$ is causing significant destructive changes to the anode because there is not a dramatic decline in the powder density or polarization cures. It is more likely that the 
electrical contact between the fuel cell and the manifolds is degrading. The lack of anode reconstruction is confirmed in the later materials characterization (Section 4.3).

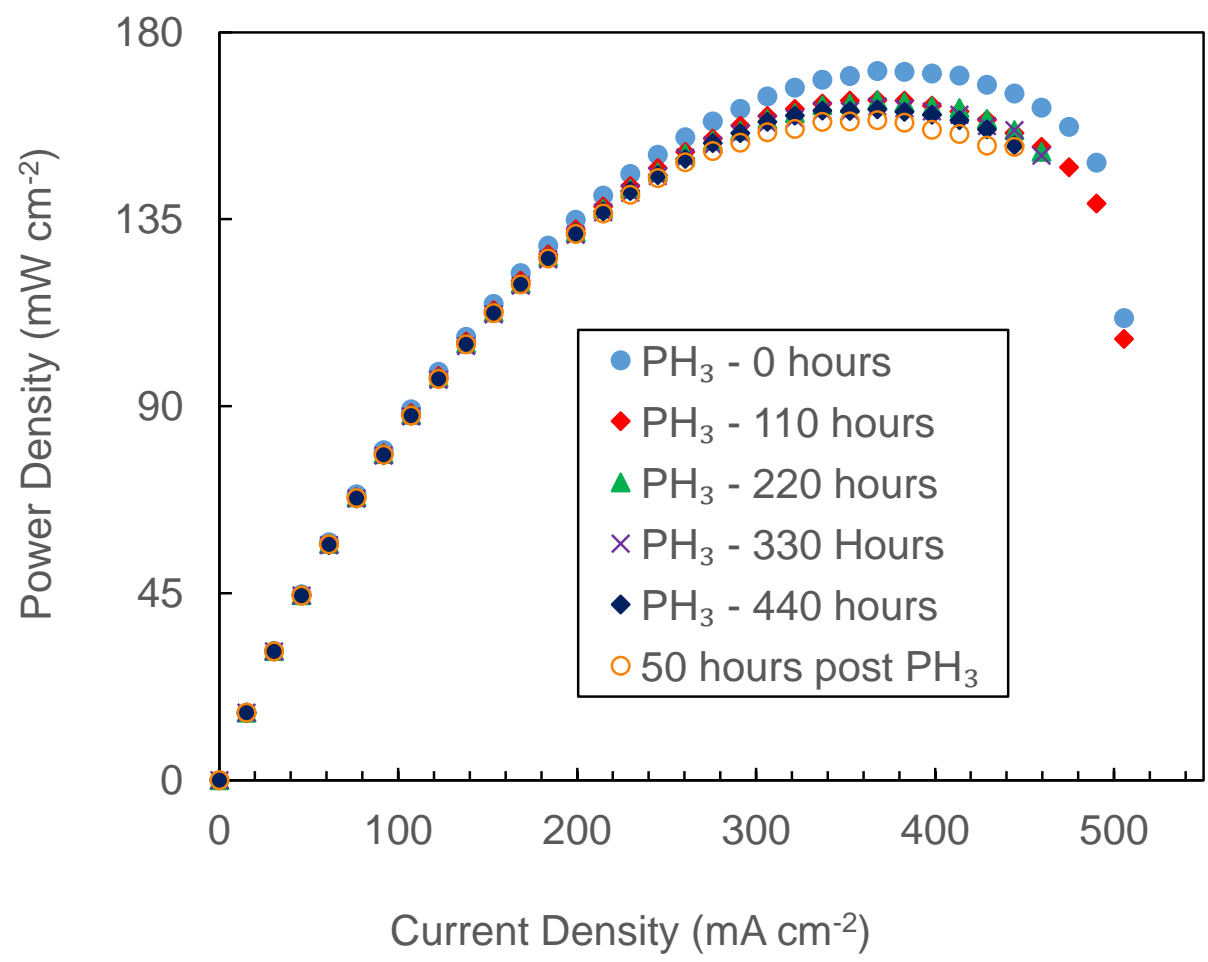

Figure 4.13 The peak power density was $170 \mathrm{~mW} \mathrm{~cm}^{-2}$ after the 187 hour burn-in period. There was a $6.2 \%$ decrease after introduction of $\mathrm{PH}_{3}$ contaminated fuel, but this stabilized over the rest of the test.

Moreover, the impedance data did not change significantly during testing. Figure 4.14 shows the impedance spectra at $\mathrm{OCV}$. $R_{\Omega}$ initially is $0.47 \Omega \mathrm{cm}^{2}$ and stays within $\pm 0.01 \Omega \mathrm{cm}^{2}$ over 170 hours of operation with $\mathrm{PH}_{3}$. This is comparable to the $R_{\Omega}$ of the $\mathrm{H} 14$ baseline $\mathrm{H}_{2}$ test, which was $0.58 \Omega \mathrm{cm}^{2}$ after 500 hours of operation. The total polarization resistance $\left(R_{\text {total }}\right.$ shifted to the right, from approximately 1.24 to $1.32 \Omega \mathrm{cm}^{2}$. This was less than the $\mathrm{H} 14$ baseline test value of $1.5 \Omega \mathrm{cm}^{2}$. These values can only my approximated since the axis did not cross the x-axis at low frequencies. It can be inferred that since $R_{\Omega}$ (left intercept) is mostly constant, $R_{p}$ (activation and concentration 
polarizations) are increasing, because the distance between two intercepts is increasing. It is difficult to separate the contributions of the concentration and activation polarizations using impedance data. As was observed with the power density, there is an initial change upon introduction of $\mathrm{PH}_{3}$ that remained constant over the duration of operation with $\mathrm{PH}_{3}$.

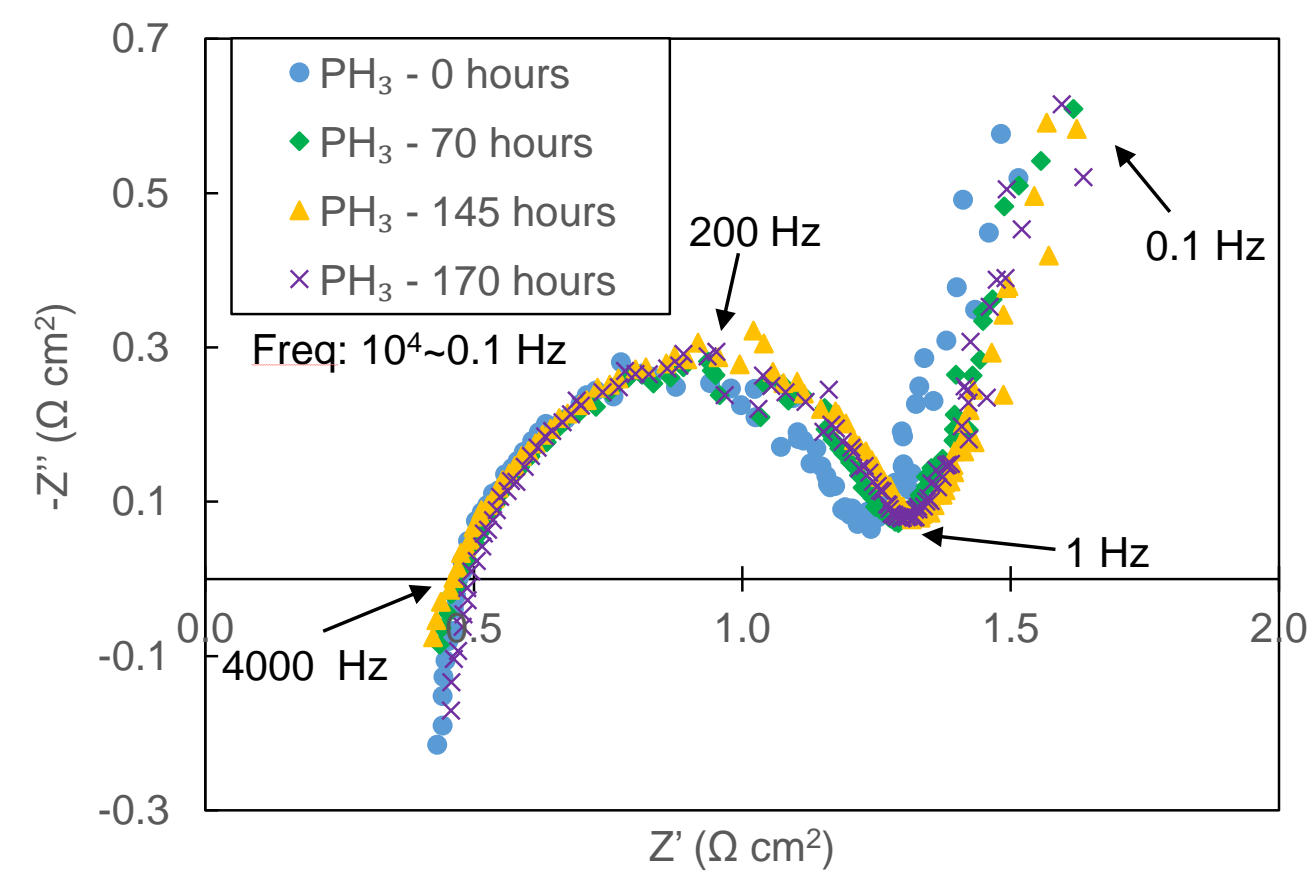

Figure 4.14 Impedance spectra at OCV. The left intercept occurs at 4000 $\mathrm{Hz}$ and the right intercept would be near $1 \mathrm{~Hz}$.

The Bode plot of the "imaginary" impedance of Figure 4.15 shows virtually no change over 170 hours EIS was collected. If any of the specific resistances of the operation (such as anode concentration polarization, anode charge transfer reaction, etc.) were increasing due to $\mathrm{PH}_{3}$ poisoning, portions of the curve should be shifting up to show the increasing resistance. There is a slight change in the region from 150$10,000 \mathrm{~Hz}$, associated with the anode charge transfer reaction, which would be related 
to the increase in $R_{p}$ observed in Figure 4.14. Figure 4.15 differs from Figure 4.7 in that the burn-in time has already been completely by the time $\mathrm{PH}_{3}$ is introduced, and is not indicated on this plot.

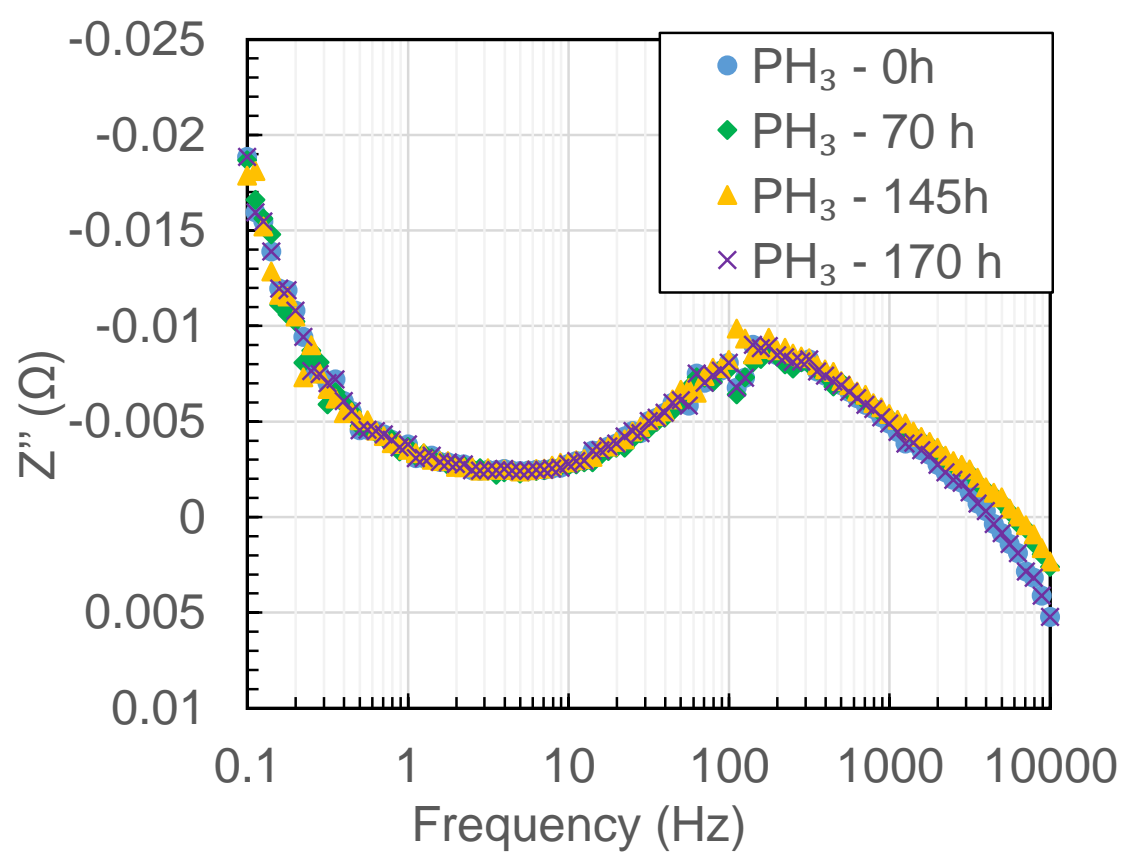

Figure 4.15 Bode plot showing minimal changes over 170 hours of operation. Curves would be shift up if any of the resistances were significantly increasing.

\subsection{Materials Characterization}

The performance data indicated that there was no negative effect of the $\mathrm{PH}_{3}$ on the operation of the SOFC. The microstructure of the anode was investigated using SEM, XRD, and XPS to determine any structural differences with the baseline cells operated with pure $\mathrm{H}_{2}$. 
Figure 4.16 shows the anode and manifold during the extraction of the fuel cell from the manifolds following the extended testing with $\mathrm{PH}_{3}$. There is no visible iridescent sheen typical of $\mathrm{PH}_{3}$ poisoning (refer to Figure 2.5). The cell exposed to the $\mathrm{PH}_{3}$ looks nearly identical to the cell operated with only pure $\mathrm{H}_{2}$ fuel. Figure 3.12 is reproduced here for reference to position locations for sample acquisition. "P1" refers to the sample taken at the inlet, "P2" refers to the sample taken at the outlet, etc. These labels are primarily used in the legend entries of the graphs.
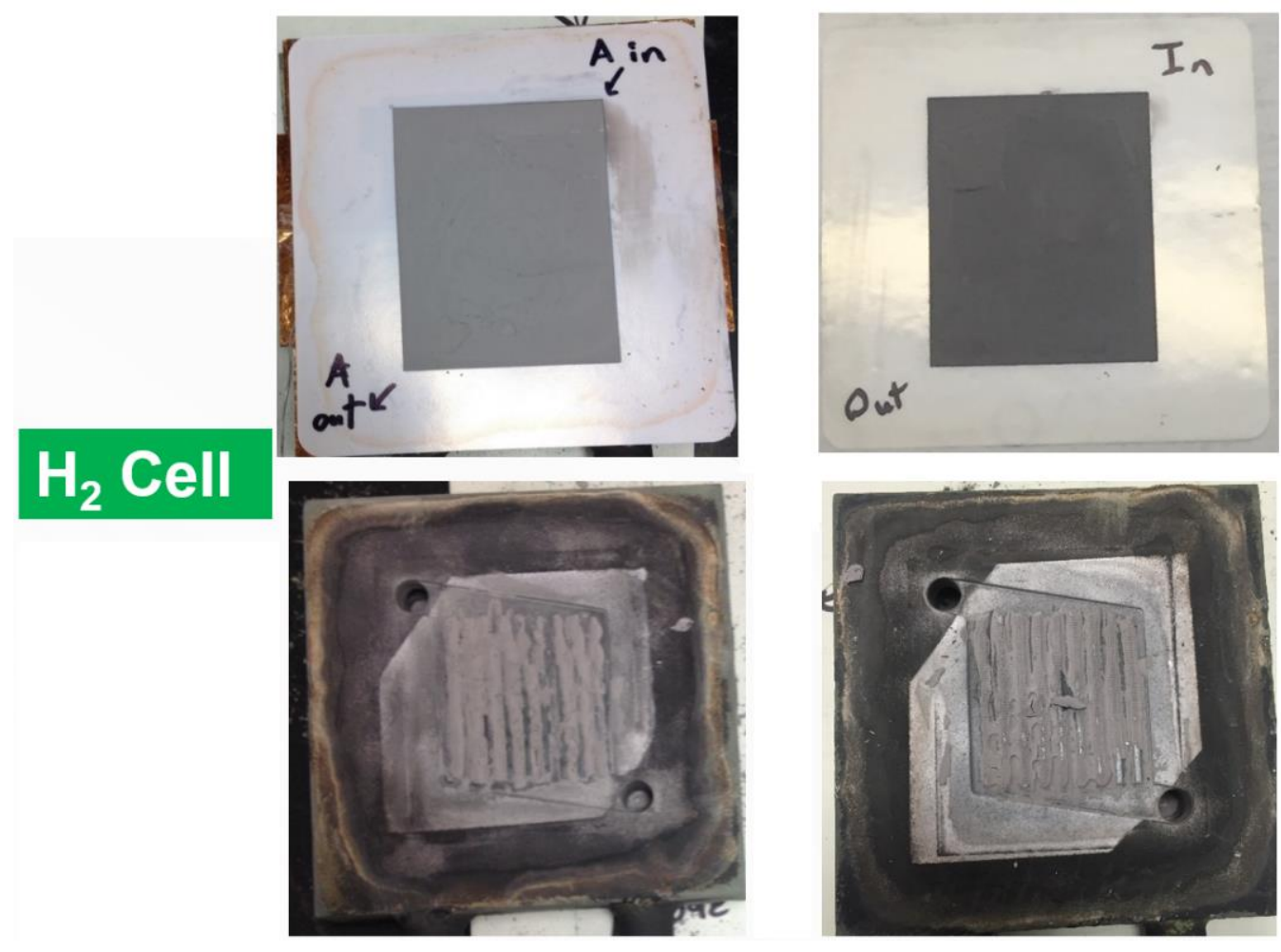

\section{$\mathrm{PH}_{3}$ Cell}

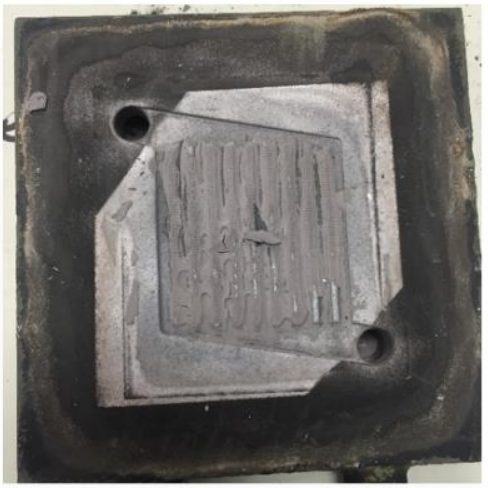

Figure 4.16 Images of cell and manifolds after running for 500+ hours in pure $\mathrm{H}_{2}$ (left) and $10 \mathrm{ppm}$ of $\mathrm{PH}_{3}$ in $\mathrm{H}_{2}$ (right). There are no differences observable to $\mathrm{PH}_{3}$ poisoning. There is slightly more oxidation on the edges of the $\mathrm{H}_{2}$ cell manifold attributable to a less than ideal seal by the mica gaskets. 


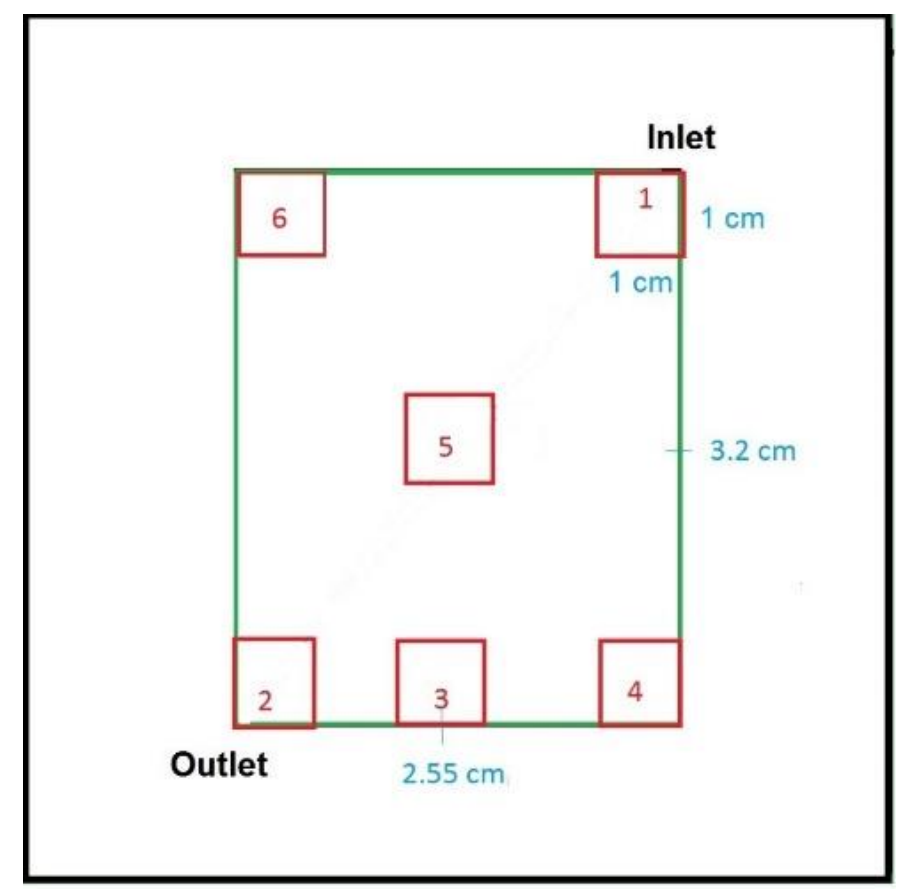

Figure 3.12 Specific positions of sample locations to be taken from each planar SOFC after testing.

\subsubsection{X-ray Diffraction (XRD) Analysis}

Figure 4.17 overlays the XRD spectra for each sample from the second fuel cell exposed to $\mathrm{PH}_{3}$. These spectra are very similar to Figure 4.18, which is the XRD analysis for the cell operated solely with pure $\mathrm{H}_{2}$ fuel. The broad peak at $26^{\circ}$ indicated by a "0" for the "holder" is an artifact as a result of using mylar film and vacuum grease to seal the sample in the XRD sample holder. Each sample was nearly identical and there were no peaks corresponding to Ni-P phases suggested by the literature. If $\mathrm{Ni}-\mathrm{P}$ phases had occurred, as in Figure 4.19 [32], the corresponding peaks would be clustered around the primary nickel peak at $44.6^{\circ}$.

There are weak peaks observable for GDC, $\mathrm{Pt}$, and $\mathrm{Yttria}\left(\mathrm{Y}_{2} \mathrm{O}_{3}\right)$, and these weak peaks differ between the samples. However, Ni and YSZ are the dominant peaks for each sample. Ni and YSZ have the most intense peaks, indicating that they are the 
dominant materials on the surface of the anode. There appear to be no gradients (such as $\mathrm{NiO}$ at the outlet (P2) and not the inlet (P1) due to the increased water content, or phosphorus compounds at the inlet (P1) where the $\mathrm{PH}_{3}$ concentration would be highest) across the cell surface due to the near-uniformity of the spectra across sample positions. There are no $\mathrm{NiO}$ peaks observed, indicating that the preservation methodology limited the samples' exposure to the ambient environment. Additionally, the inlet and outlet tubes of the manifold were examined for any debris or scaling on the surfaces. None was observed so it is unlikely that the $\mathrm{PH}_{3}$ was reacting significantly with the Incone $l^{\circledR} 601$ of the inlet and exhaust tubes.

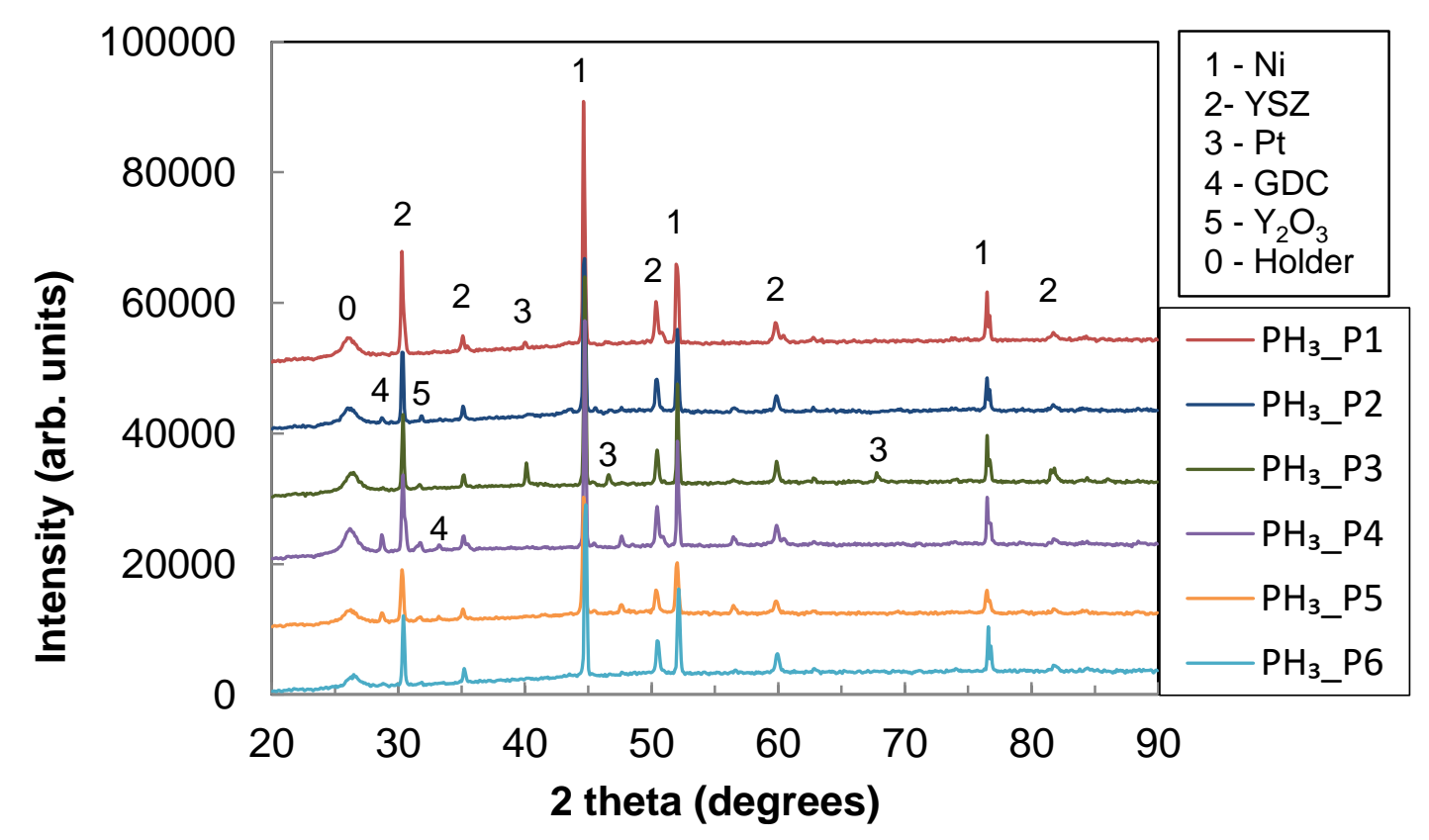

Figure 4.17 Overlay of XRD spectra for SOFC anode exposed to $10 \mathrm{ppm}$ $\mathrm{PH}_{3}$ in $\mathrm{H}_{2}$. No peaks corresponding to any Ni-P phases are observable. Spectra are nearly identical to those in Figure 4.15. 


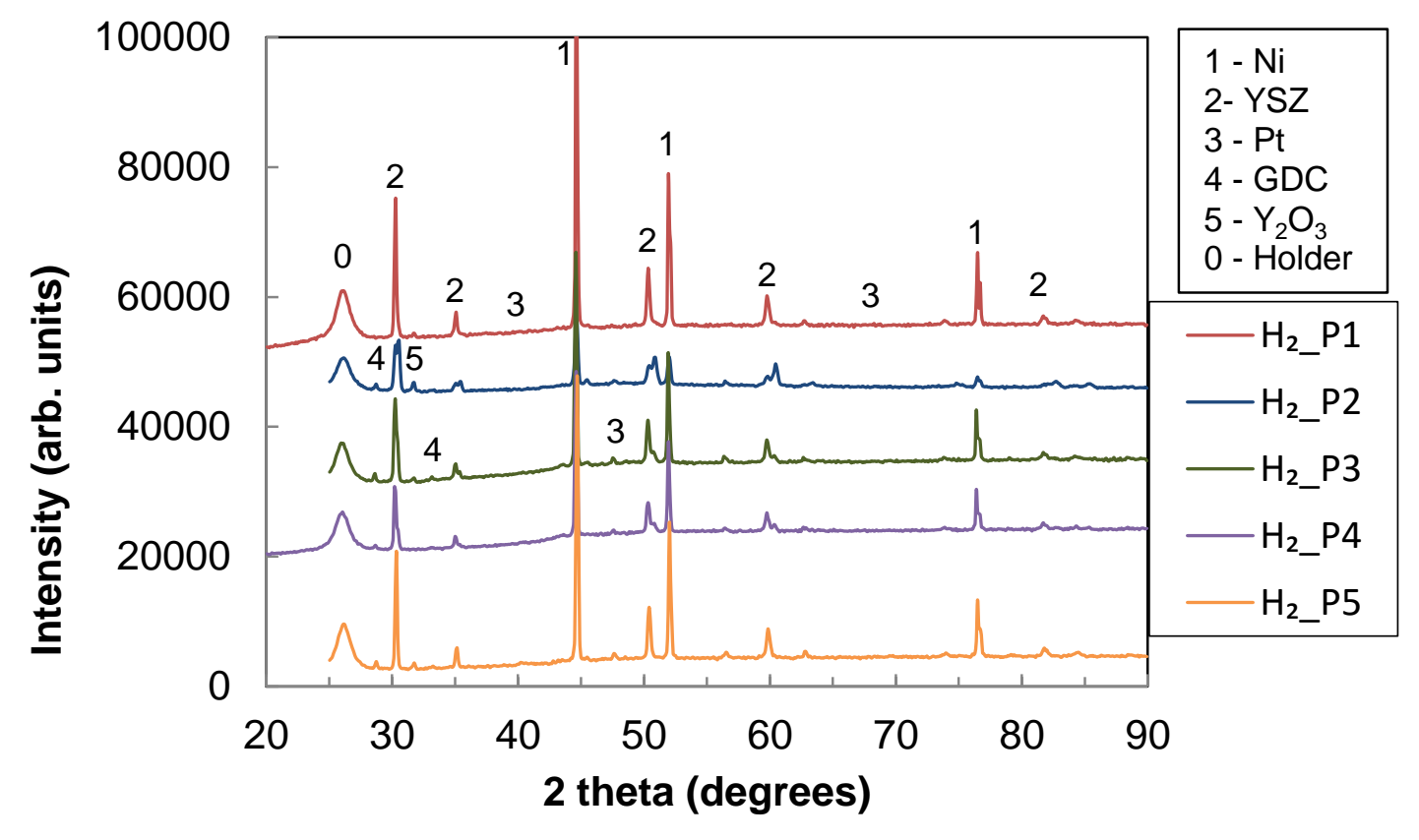

Figure 4.18 Overlay of XRD spectra for SOFC using pure $\mathrm{H}_{2}$ fuel.

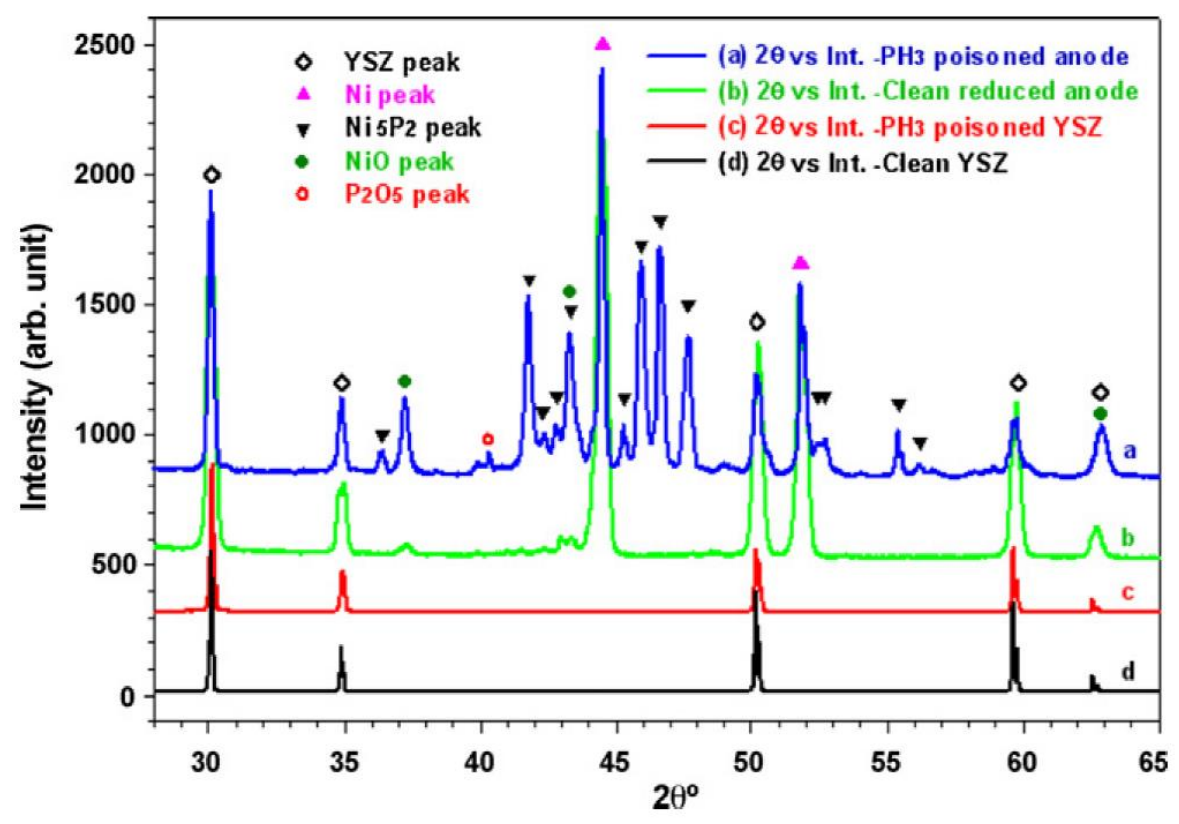

Figure 4.19 XRD spectra from button cell $\mathrm{PH}_{3}$ experiment. Ni-P phases are clustered around the Ni peak at $44.6^{\circ}$ [32]. 
The lack of any observable Ni-P phases is a very interesting result. Nearly all button cell experimentation with $\mathrm{PH}_{3}$ contaminated fuel has resulted in the formation of Ni-P phases [20], [21], [22], [35], [40] on the surface of the anode. Martinez et al. [56] conducted a thermodynamic analysis of syngas produced from a variety of gasifiers and how the varying compositions produced by these gasifiers would affect the $\mathrm{Ni}$ component of a typical SOFC anode. The thermodynamic analysis of the entrained and Sarlux gasifiers indicated little to no Ni-P formation. This was attributed to the syngas being rich in steam. The additional oxygen (from the $\mathrm{H}_{2} \mathrm{O}$ ) generates phosphorous trioxides $\left(\mathrm{P}_{2} \mathrm{O}_{3}\right)_{2}(\mathrm{~g})$, at an anode operating temperature of $800^{\circ} \mathrm{C} .\left(\mathrm{P}_{2} \mathrm{O}_{3}\right)_{2(\mathrm{~g})}$ forms preferentially over the $\mathrm{Ni}-\mathrm{P}$ phases, thereby removing the phosphorus from participation in a reaction with anodic nickel. A similar but diminished effect is also observed with the catalytic gasifier.

Zhang [57] performed experiments to study reactions of $\mathrm{PH}_{3}, \mathrm{H}_{2} \mathrm{O}$, and $\mathrm{Ni} / \mathrm{YSZ}$ at high temperatures. Loss of $\mathrm{PH}_{3}$ was observed in the majority of the tests, but was unable to confirm the resulting molecular species due to the detection limits of the mass spectrometer used in the study. Kisimoto et al. [58] generated Ellingham diagrams for utilization in solid oxide fuel cells. These were P-O-H and Ni-P-O-H systems. There are a wide range of products suggested by these diagrams that should be investigated.

The results of Martinez et al. [56] are very relevant to this project. The fuel utilization of $12.5 \%$ used for the large planar cells is an order of magnitude larger than typical button cell testing. Xu et al. had a fuel utilization of 3.5\% [32]. A higher fuel utilization means more $\mathrm{H}_{2}$ is being converted to $\mathrm{H}_{2} \mathrm{O}$. In the present work, there is a much higher steam content in the anode reaction chamber that appears to be 
preventing the $\mathrm{PH}_{3}$ from reacting with the $\mathrm{Ni}$ in the anode. It should be noted again that in this project, no steam is fed with the fuel. Steam is only present as the product of the oxidation reaction that occurs at the anode.

Krishnam et al. [30] performed a variety of experiments analyzing the effect of trace contaminants on SOFC anodes. Regarding phosphorus testing, they found that $\mathrm{PH}_{3}$ in the presence of steam forms $\mathrm{HPO}_{2}$ and $\mathrm{HPO}_{3}$ via the reactions:

$$
\begin{aligned}
& \mathrm{PH}_{3}(g)+2 \mathrm{H}_{2} \mathrm{O}(g) \rightarrow \mathrm{HPO}_{2}(g)+3 \mathrm{H}_{2}(g) \\
& \mathrm{PH}_{3}(g)+3 \mathrm{H}_{2} \mathrm{O}(g) \rightarrow \mathrm{HPO}_{3}(g)+4 \mathrm{H}_{2}(g)
\end{aligned}
$$

These compounds are different than the results suggested by Martinez et al. [56]. While these compounds might not react with the $\mathrm{Ni}$ in the anode, they could still potentially react with the YSZ to form ytrrium or zirconium phosphates. These phosphates would reduce the ability of the YSZ to conduct the oxygen ions which is crucial to the performance of the fuel cell. However, these $\mathrm{PH}_{3}$ decomposition reactions only occurred at very high steam ratios $\left(\sim 6000 \mathrm{H}_{2} \mathrm{O} / \mathrm{PH}_{3}\right)$ indicating that unreacted $\mathrm{PH}_{3}$ could still reach the anode [30] and react there. More importantly, no yttrium or zirconium phosphates were observed in the XRD spectra for the fuel cells tested here.

A layer of the platinum paste from the anode center (near P5) was analyzed with the XRD. The primary peaks at $39.9^{\circ}, 46.6^{\circ}, 67.6^{\circ}, 81.5^{\circ}$, and $85.9^{\circ}$, shown in Figure 4.20, all correspond to pure platinum. There were no residual phosphorus compounds within this area of the anode in the platinum layer. 


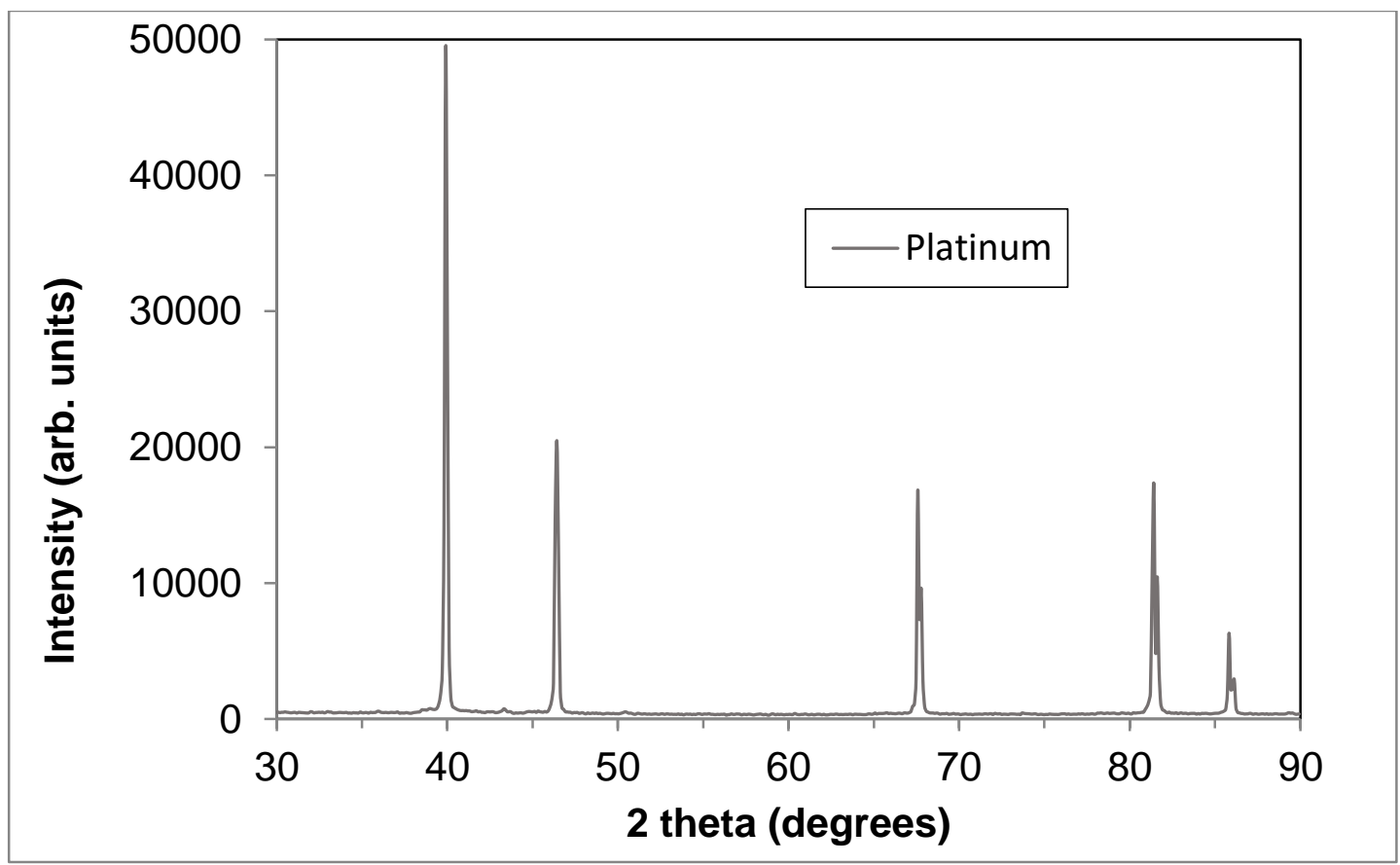

Figure 4.20 Platinum layer near the center of the anode showed no residual phosphorus compounds. 


\subsubsection{X-ray Photoelectron Spectroscopy (XPS) Analysis}

XPS is more sensitive to individual elements than XRD. Survey scans along the entire spectral range identify the major peaks, or what elements are present on the sample. Detail scans are then conducted to identify more completely the specific binding energies present for specific elements. The detail peak scans were conducted for carbon 1s, oxygen 1s, nickel 2p, yttrium 3d, zirconium 3d, and phosphorus 1s and $2 p$. Phosphorus was included in the detail scans even if the initial survey scan did not indicate its presence.

XPS spectra did not show any evidence of Ni-P bonding. The primary Ni $2 p$ peak for pure Ni has a binding energy of $852.6 \mathrm{eV}$. Any type of bonding increases this value. $\mathrm{NiO}$ occurs at $853.7 \mathrm{eV}$ and Ni-P would occur at $854.6 \mathrm{eV}$. Figure 4.21 shows location $\mathrm{P} 1$, the gas inlet sample location, is nearly identical between the sample exposed to 10 ppm $\mathrm{PH}_{3}$ and the sample operated only in pure $\mathrm{H}_{2}$. The primary Ni peak is at $852.3 \mathrm{eV}$ for both the baseline $\mathrm{H}_{2}$ and $\mathrm{PH}_{3}$ samples. Figure 4.22 shows there is no peak present in the phosphorus $2 p 3 / 2$ binding energy range, indicating that there is no phosphorus present in the sample bonded to any elements. 


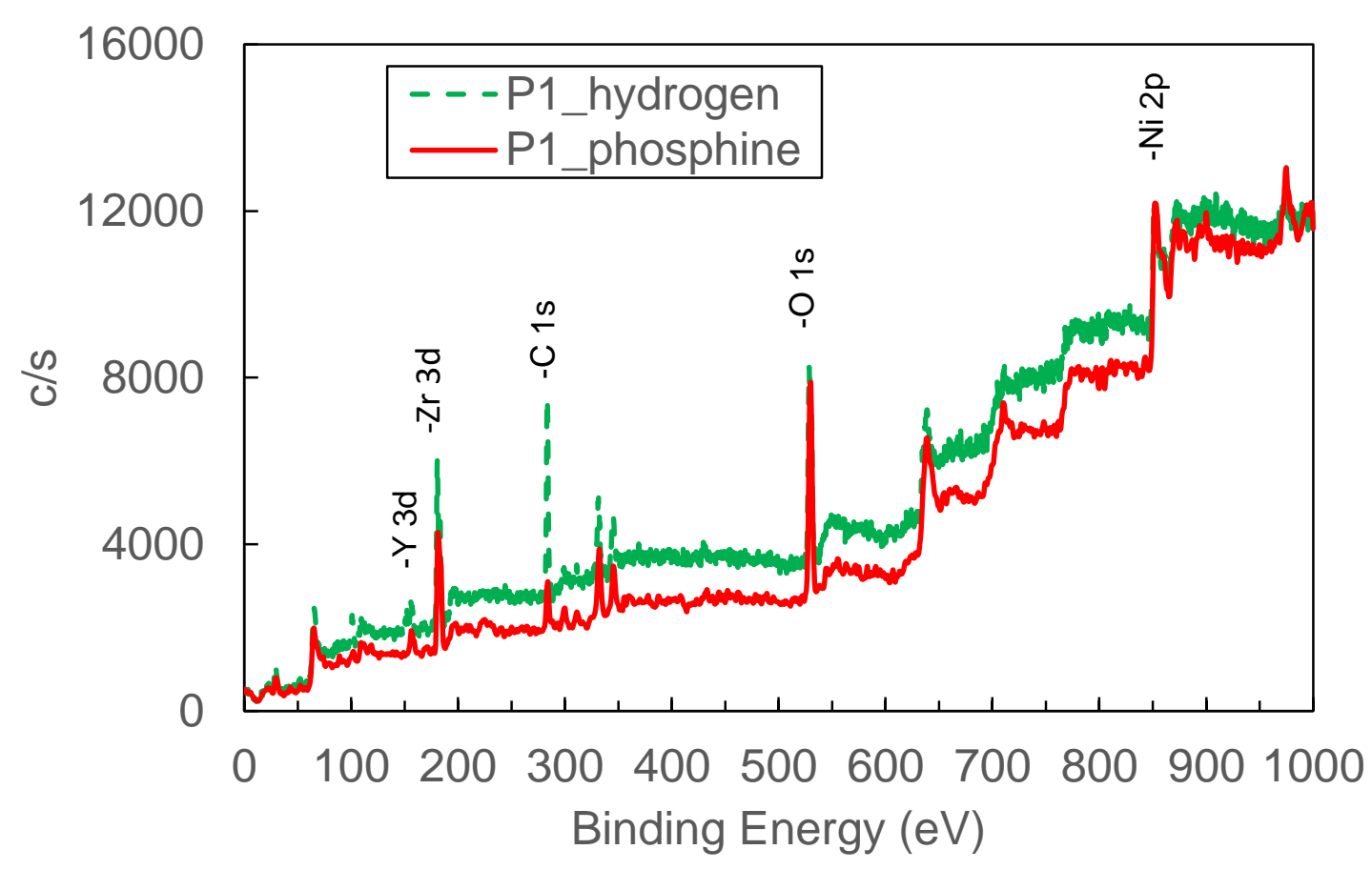

Figure 4.21 XPS spectra comparing location $\mathrm{P} 1$ of baseline $\mathrm{H}_{2}$ anode to location $\mathrm{P} 1$ of anode exposed to $10 \mathrm{ppm} \mathrm{PH}_{3}$.

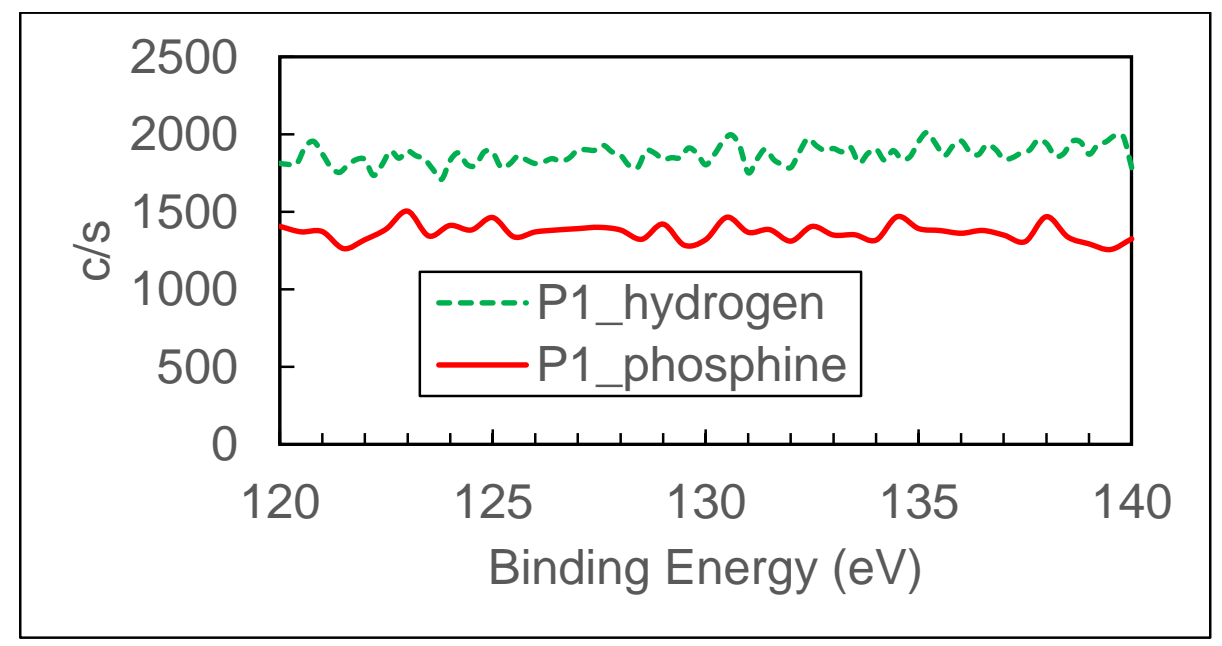

Figure 4.22 There is no evidence of phosphorus on the surface of the sample at location P1. Phosphorus $2 p 3 / 2$ binding energy peak should occur at $130.2 \mathrm{eV}$ and there is no peak in this range.

The presence of $Y$ and $\mathrm{Zr}$ peaks in Figure 4.21 further indicates that there are no $\mathrm{Ni}-\mathrm{P}$ phases. If phosphorus was reacting with the nickel, these Ni-P compounds should 
be agglomerating and covering the surface of the anode, eliminating the appearance of YSZ at the surface. YSZ is still present at the surface so there is no migration of nickel species to the anode surface as indicated in the literature. There is also no indication of yttrium and zirconium phosphates, which could occur as a result of $\mathrm{PH}_{3}$ decomposition to $\mathrm{HPO}_{2}$ and $\mathrm{HPO}_{3}[30]$.

Figure 4.23 compares the spectra at location P2, the anode outlet, of the baseline $\mathrm{H}_{2}$ cell and the cell exposed to $10 \mathrm{ppm} \mathrm{PH}_{3}$. It is similar to the spectra at $\mathrm{P} 1$. The primary Ni 2p peak at $\mathrm{P} 2$ for the baseline $\mathrm{H}_{2}$ and $\mathrm{PH}_{3}$ samples are at $852.0 \mathrm{eV}$ and $852.2 \mathrm{eV}$, respectively, indicating that it is fully reduced Ni. Figure 4.24 focuses on the $\mathrm{P}$ $2 \mathrm{p}$ peak location. As with location $\mathrm{P} 1$, there is no indication of phosphorus being present in the sample.

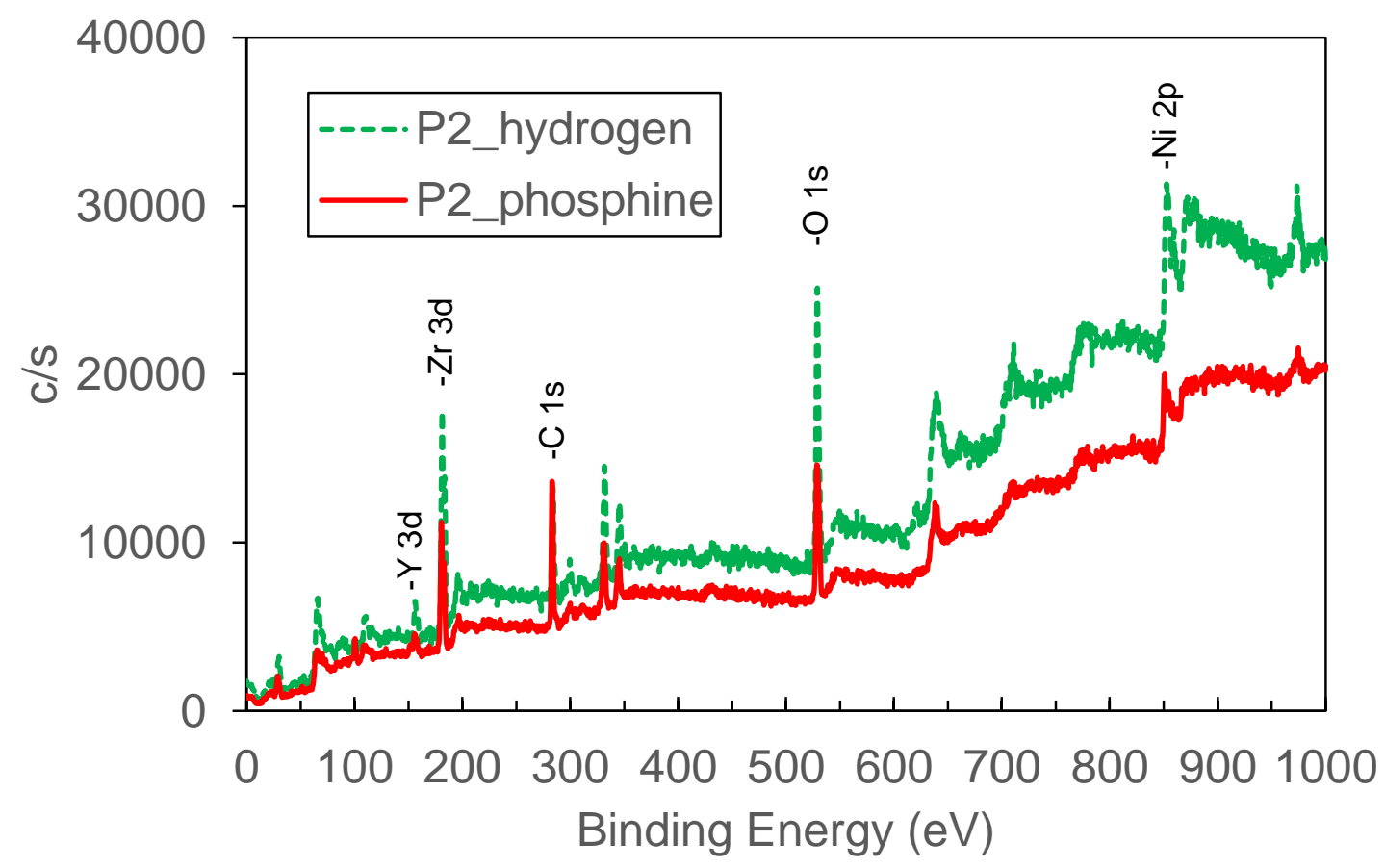

Figure 4.23 XPS spectra comparing location $\mathrm{P} 2$ of baseline $\mathrm{H}_{2}$ anode to

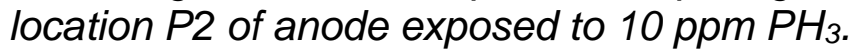




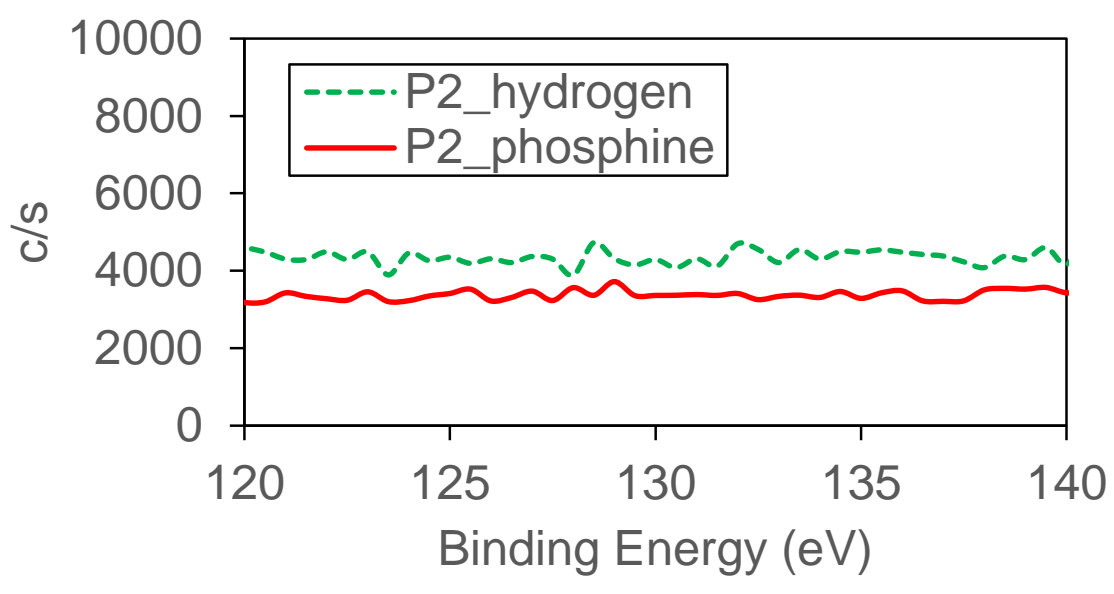

Figure 4.24 There is no evidence of phosphorus on the surface of the sample at location P2. Phosphorus $2 p 3 / 2$ binding energy peak should occur at $130.2 \mathrm{eV}$ and there is no peak in this range.

Figure 4.25 compares the spectra at location P5, the anode center, for the baseline $\mathrm{H}_{2}$ cell and the cell exposed to $10 \mathrm{ppm} \mathrm{PH}_{3}$. It is similar to the spectra at $\mathrm{P} 1$ and P2. The primary Ni $2 p$ peak at $\mathrm{P} 5$ for the baseline $\mathrm{H}_{2}$ and $\mathrm{PH}_{3}$ samples are at 852.3 $\mathrm{eV}$ and $852.1 \mathrm{eV}$, respectively, indicating that it is fully reduced $\mathrm{Ni}$. 


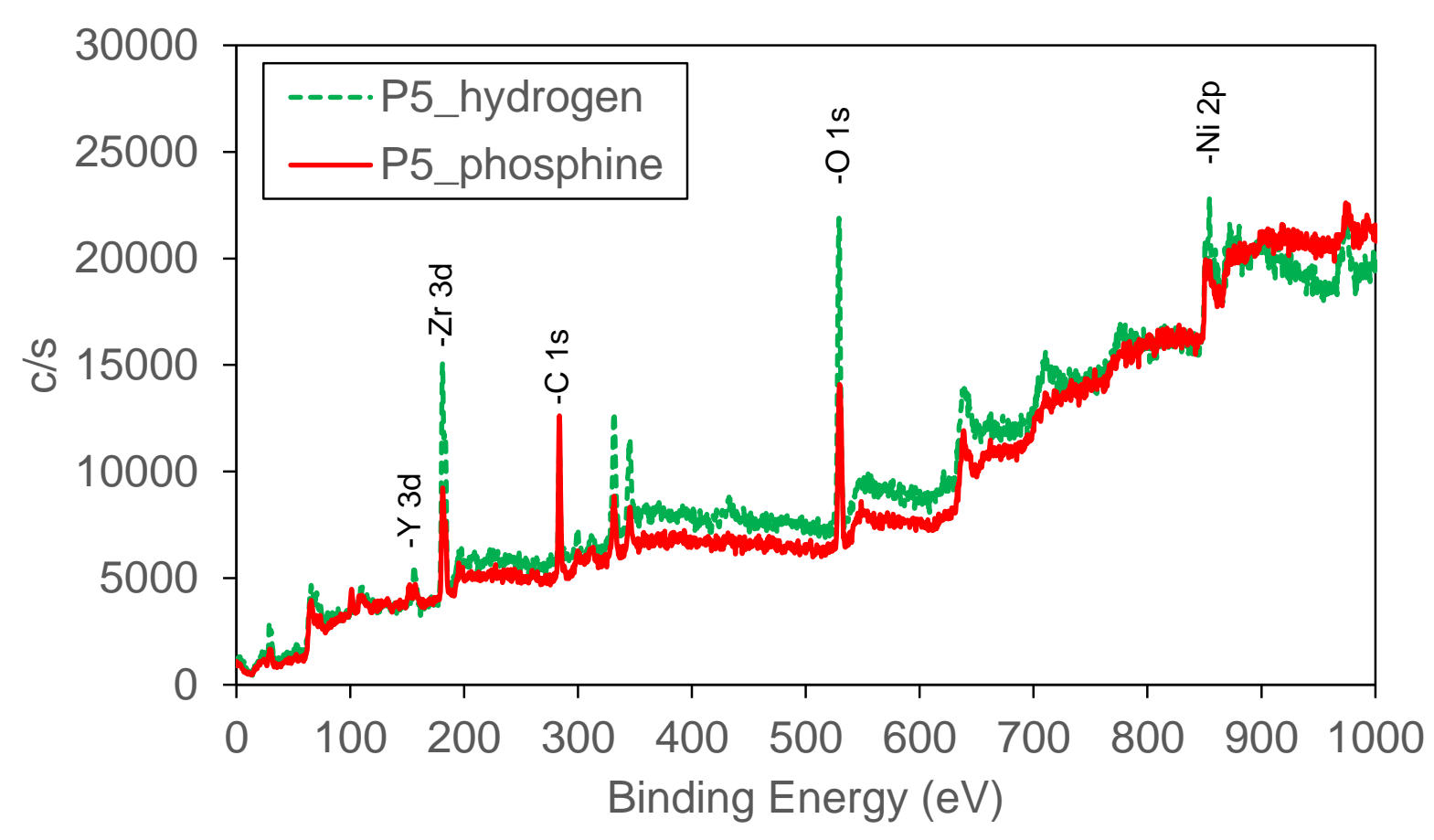

Figure 4.25 XPS spectra comparing location $\mathrm{P} 5$ of baseline $\mathrm{H}_{2}$ anode to location $\mathrm{P} 5$ of anode exposed to $10 \mathrm{ppm} \mathrm{PH}_{3}$.

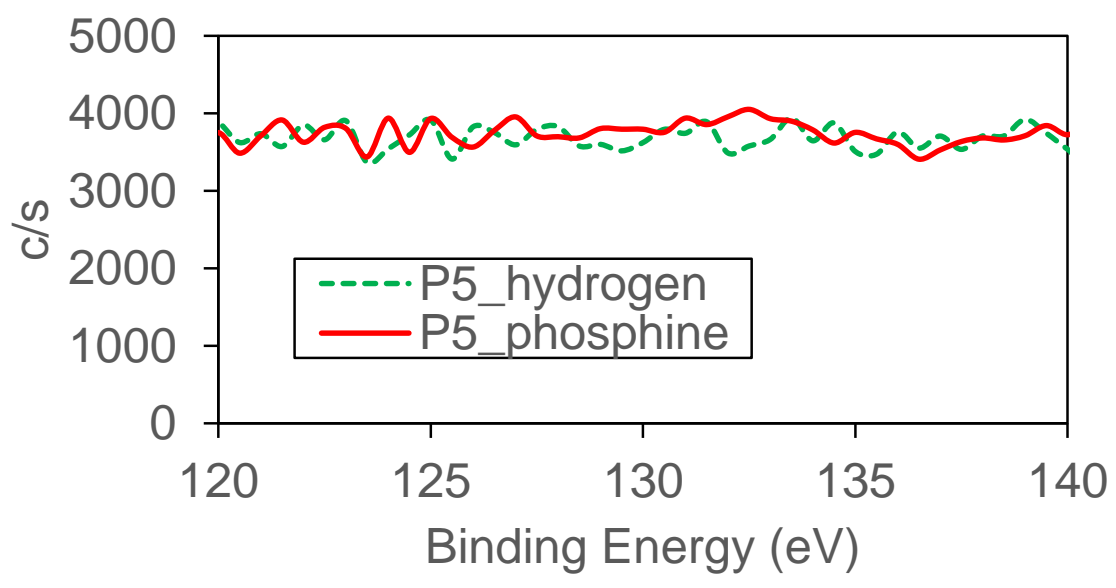

Figure 4.26 There is no evidence of phosphorus on the surface of the sample at location P5. Phosphorus $2 p 3 / 2$ binding energy peak should occur at $130.2 \mathrm{eV}$ and there is no peak in this range. 
The layer of the platinum paste from the anode center was analyzed with XPS. The peaks observed in Figure 4.27 corresponded to oxygen 1s, carbon 1s, and the various Pt orbitals. There were no phosphorus peaks observed. This confirms the initial XRD assessment of no residual phosphorus in the Pt layer.

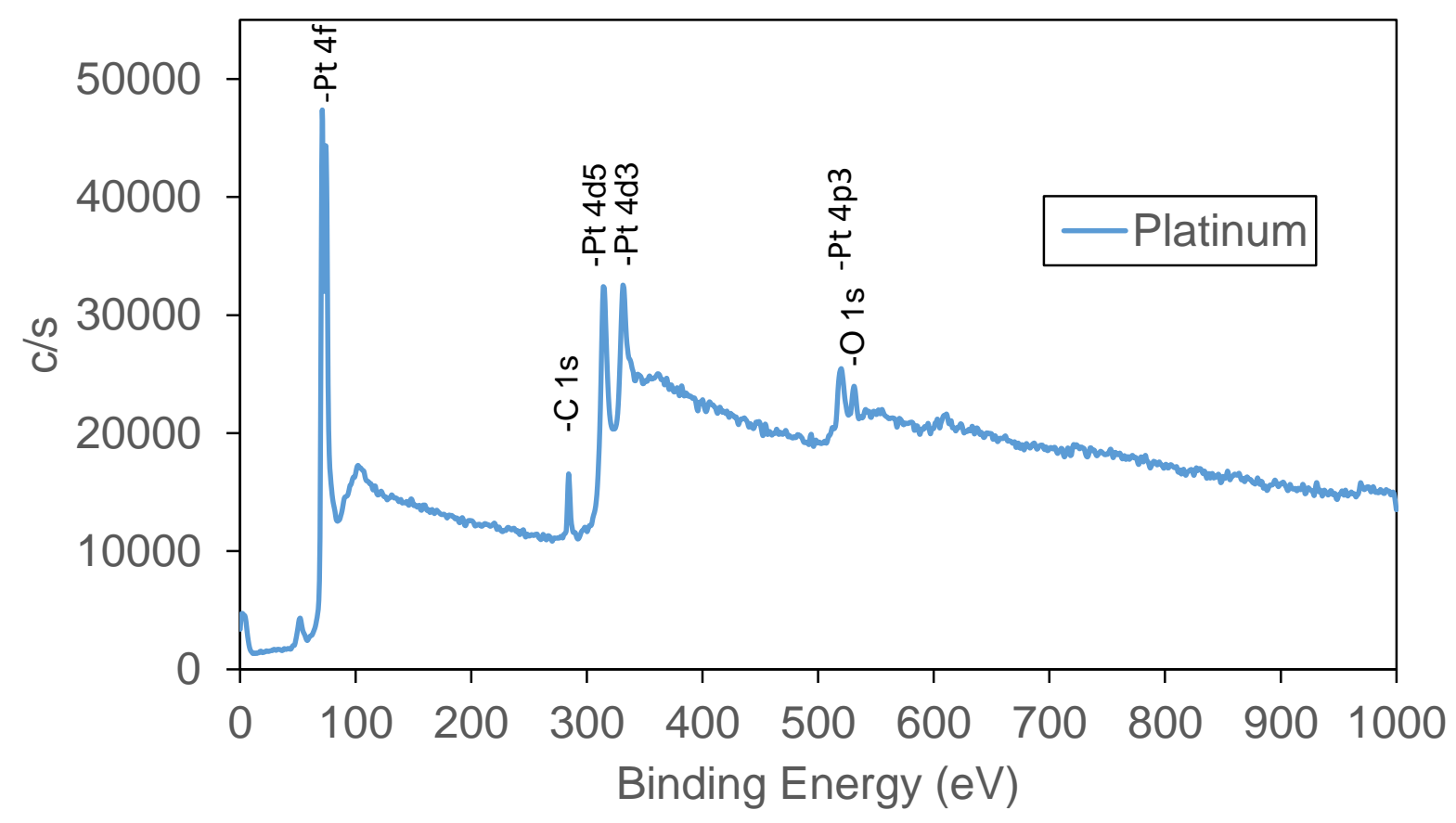

Figure 4.27 Platinum layer from anode shows no residual phosphorus. 


\subsubsection{Scanning Electron Microscopy (SEM) Analysis}

There was further indication of no bulk Ni-P phases forming on the fuel cell surface via SEM analysis. SEM images comparing the baseline $\mathrm{H}_{2}$ samples to samples operated with $10 \mathrm{ppm} \mathrm{PH}_{3}$ showed minimal differences. Figure 4.28 (a) shows the clean reduced anode at location $\mathrm{P} 1$ (gas inlet) of the baseline $\mathrm{H} 2$ cell. Figure 4.28 (b) shows the pore structure at location P1 fully intact after operation for 450 hours with $10 \mathrm{ppm}$ $\mathrm{PH}_{3}$

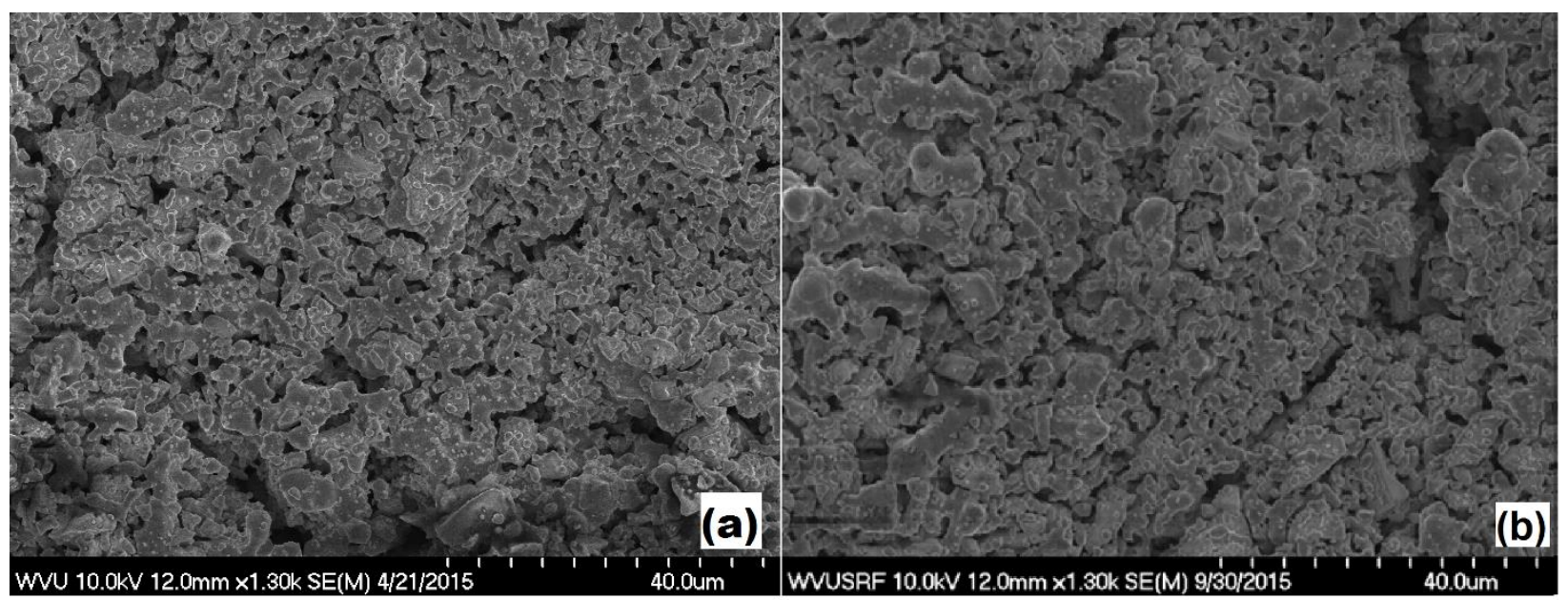

Figure 4.28 (a) Clean reduced anode surface SEM micrograph at location $P 1$ of baseline $\mathrm{H}_{2}$ sample and (b) fuel cell exposed to $10 \mathrm{ppm} \mathrm{PH} 3$ for 450 hours. The pore structure is intact and there is no Ni-P formation on the surface. 
There is also no evidence of Ni-P phases at position P2 (gas outlet). Figure 4.29

(a) shows the clean reduced anode at location P2 of the baseline $\mathrm{H}_{2}$ cell. Figure 4.29

(b) again shows the pore structure at location P2 fully intact after operation for 450 hours with $10 \mathrm{ppm} \mathrm{PH}_{3}$.

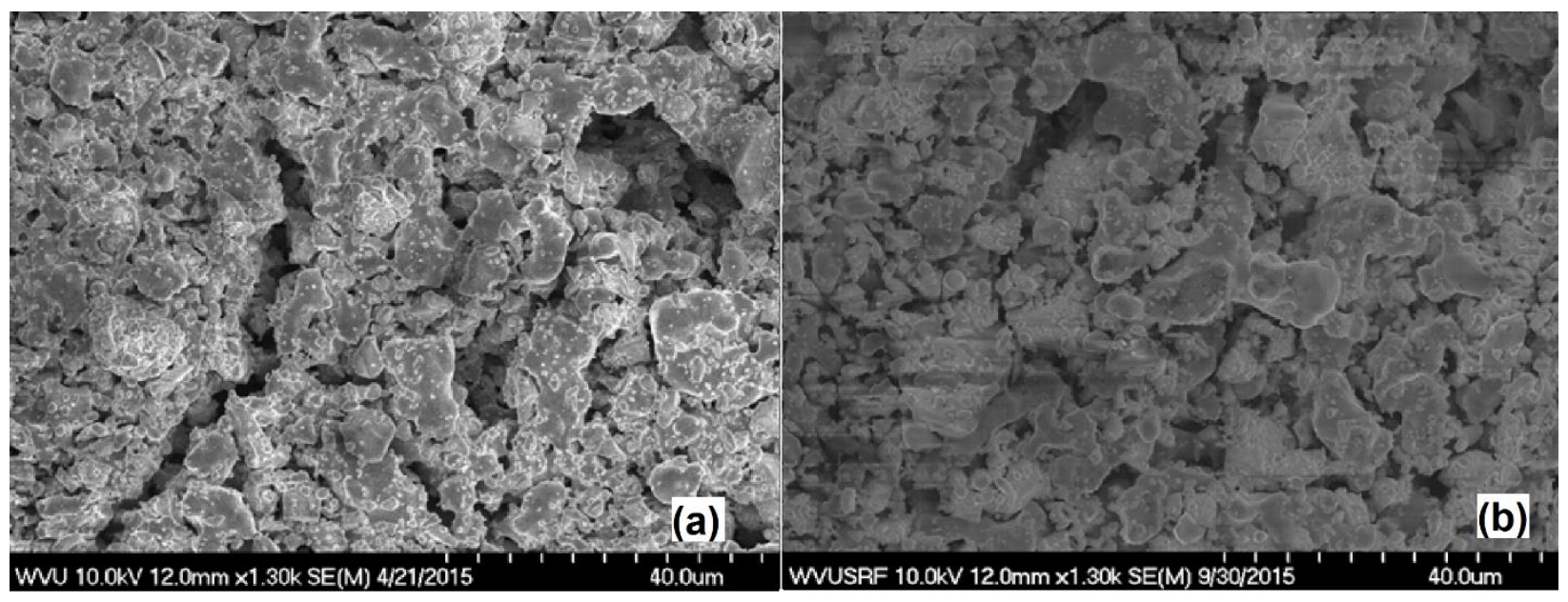

Figure 4.29 (a) Clean reduced anode surface SEM micrograph at location $\mathrm{P} 2$ of baseline $\mathrm{H}_{2}$ sample and (b) fuel cell exposed to $10 \mathrm{ppm} \mathrm{PH} \mathrm{P}_{3}$ for 450 hours. The pore structure is intact and there is no Ni-P formation on the surface.

Figure 4.30 is the cross sectional micrograph at location P5, the center of the anode, for the fuel cell exposed to $10 \mathrm{ppm} \mathrm{PH}_{3}$. The dense electrolyte layer is to the left, with the Ni/GDC layer next to it, then the porous Ni/YSZ next to it. There is no evidence of phosphorus penetration into the top anode layer or any rearrangement of the anode surface. The anode structure remains similar to that in Figure 4.31, the cross sectional micrograph at location P5 of the baseline $\mathrm{H}_{2}$ cell. In Figure 4.31, the electrolyte layer is on the right side of the image, and there is not as clear a division of the Ni/GDC and $\mathrm{Ni} /$ YSZ layers as in Figure 4.30. Both Figures 4.30 and 4.31 show the complex pore structure of the anode leading to the TPB at the electrolyte. 


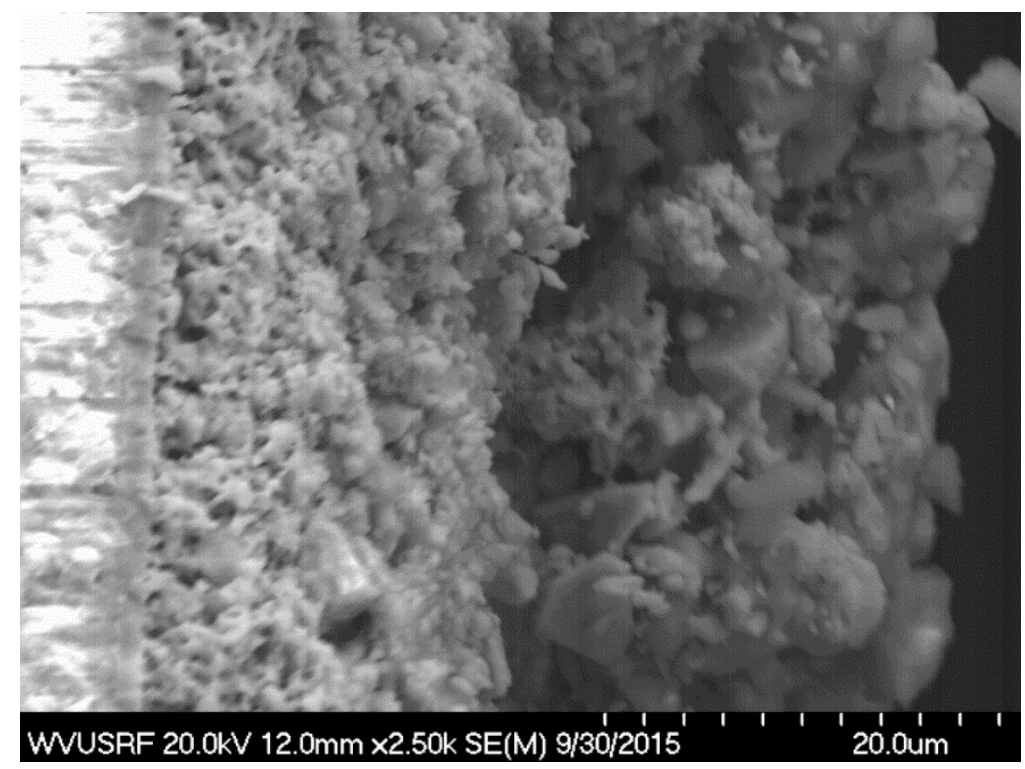

Figure 4.30 Cross sectional SEM micrograph at location P5 of anode exposed to $10 \mathrm{ppm} \mathrm{PH}_{3}$. There is no evidence of phosphorus penetration into the anode. Dense electrolyte is on the left with the anode extending to the right.

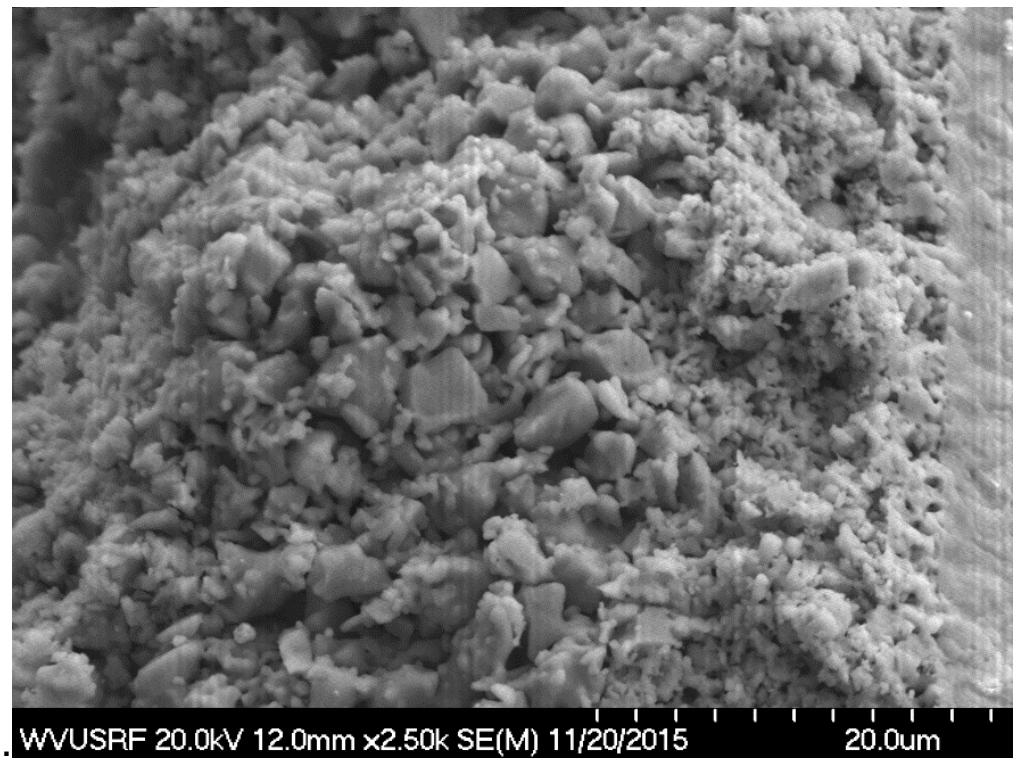

Figure 4.31 Cross sectional SEM micrograph at the center of the anode of the baseline $\mathrm{H}_{2}$ fuel cell. Dense electrolyte is on the right with anode extending to the left. 


\section{Chapter 5: Conclusions}

The work presented here investigated the effect of phosphorus impurities in the fuel gas on the nickel anode of a large, electrolyte-supported solid oxide fuel cell. The gcell had a planar configuration with a co-flow gas flow pattern similar to industrial scale fuel cell stacks. This differs from the majority of solid oxide fuel cell research conducted with $\mathrm{PH}_{3}$ contaminated fuel, where smaller button cells with the gases flowing perpendicular to the cell face rather than parallel across the cell face are used in the literature. The results obtained were also drastically different than the published literature. There was little to no degradation attributable to $\mathrm{PH}_{3}$ for a SOFC that was exposed to $10 \mathrm{ppm} \mathrm{PH}_{3}$ for 450 hours over almost 700 total hours of operating time.

In all other published literature using $\mathrm{PH}_{3}$ as the fuel contaminant, solid nickelphosphide compounds formed on the surface of the anode. This destroys the delicate pore structure required for gases to diffuse to the triple-phase boundary (TPB) and drive the electrochemical reactions. Careful material characterization was conducted to analyze the surface of the anode of the fuel cell and prevent any contamination from altering the results. No nickel-phosphide compounds, or any phosphorus compounds at all, were observed in any of the $\mathrm{x}$-ray diffraction $(\mathrm{XRD})$ patterns, $\mathrm{x}$-ray photoelectron spectra (XPS), or scanning electron micrographs (SEM).

A possible explanation is the increased water content as a result of the increased fuel utilization of the large planar cell facilitating competing gas-phase reactions with the $\mathrm{PH}_{3}$ that form compounds that do not react with the $\mathrm{Ni}$ in the anode. Platinum was used for anode chamber components (current collector, contact paste, etc.) and platinum catalyzes a wide range of reactions. The fuel utilization used in this project was $12.5 \%$ 
which is larger than the $\sim 3.5 \%$ fuel utilization of typical button cell experiments. Hence, a larger percentage of the hydrogen fuel is being converted to water in the large planar cells. Phosphine was measured before the inlet of the anode and at the exhaust of the anode. It is confirmed that the $\mathrm{PH}_{3}$ was reaching the anode, flowing through the anode chamber, and not reacting with the Incone $\left.\right|^{\circledR}$ tubing or Haynes 242 manifold materials.

While this project may contradict the majority of the published literature, the testing configuration is the key difference from that literature. The increased fuel utilization (12.5\% vs $\sim 3.5 \%)$, fuel cell active area $\left(33 \mathrm{~cm}^{2}\right.$ vs. $\left.\sim 2 \mathrm{~cm}^{2}\right)$, gas flow configuration (co-flow/parallel vs. perpendicular), could be key parameters that prevent interaction of impurities with the anode surface. Further experimentation is necessary to prove these concepts and a deeper analysis of potential side reactions is required to understand why no degradative effect observed. 


\section{References}

[1] "Fuel Cells | Department of Energy." Accessed May 5, 2015. http://energy.gov/eere/fuelcells/fuel-cells.

[2] Mekhilef, S., R. Saidur, and A. Safari. "Comparative Study of Different Fuel Cell Technologies." Renewable and Sustainable Energy Reviews 16, no. 1 (January 2012): 981-89. doi:10.1016/j.rser.2011.09.020.

[3] Badwal, S.P.S., S. Giddey, A. Munnings, and A. Kulkarni. "Review of Progress in High Temperature Solid Oxide Fuel Cell." Journal of the Australian Ceramics Society 50, no. 1 (2014).

[4] Mahato, Neelima, Amitava Banerjee, Alka Gupta, Shobit Omar, and Kantesh Balani. "Progress in Material Selection for Solid Oxide Fuel Cell Technology: A Review." Progress in Materials Science, February 2015. doi:10.1016/j.pmatsci.2015.01.001.

[5] "The Rise of the Hydrogen Fuel Cell." Accessed May 5, 2015. http://www.forbes.com/sites/billtucker/2015/04/29/the-rise-of-the-hydrogen-fuelcell/.

[6] "Fuel Cells - a Disruptive Technology in the Changing Energy Landscape Renewable Energy Focus." Accessed May 5, 2015. http://www.renewableenergyfocus.com/view/42107/fuel-cells-a-disruptivetechnology-in-the-changing-energy-landscape/.

[7] "Energy Storage: Continuing To Evolve - Forbes." Accessed July 8, 2015. http://www.forbes.com/sites/peterdetwiler/2013/05/15/energy-storage-continuingto-evolve/.

[8] "IKEA TO EXPAND RENEWABLE ENERGY PORTFOLIO WITH FUEL CELLS TO GENERATE MORE ONSITE POWER AT STORE IN EMERYVILLE, CA - IKEA." Accessed May 5, 2015. http://www.ikea.com/us/en/about ikea/newsitem/032515 fuel-cell-systememeryville-CA. 
[9] "Layout 1 - Fuel-Cell-Technology-White-Paper.pdf." Accessed July 8, 2015. http://www.fuelcellenergy.com/assets/Fuel-Cell-Technology-White-Paper.pdf.

[10] R, Tom, and all. "Fossil Fuels Just Lost the Race Against Renewables." Bloomberg.com. Accessed July 29, 2015. http://www.bloomberg.com/news/articles/2015-04-14/fossil-fuels-just-lost-therace-against-renewables.

[11] Owens, Brandon. "The Rise of Distributed Power." Accessed July 29, 2015. http://www.ge.com/sites/default/files/2014\%2002\%20Rise\%20of\%20Distributed \%20Power.pdf.

[12] "FACT SHEET: U.S.-China Joint Announcement on Climate Change and Clean Energy Cooperation | Whitehouse.gov." Accessed July 8, 2015. https://www.whitehouse.gov/the-press-office/2014/11/11/fact-sheet-us-chinajoint-announcement-climate-change-and-clean-energy-c.

[13] Singhal, Subhash C., and Kevin Kendall, eds. High-Temperature Solid Oxide Fuel Cells: Fundamentals, Design, and Applications. New York: Elsevier Advanced Technology, 2003.

[14] "Fuel Cell Handbook (Seventh Edition) - FCHandbook7.pdf." Accessed July 27, 2015.

https://www.netl.doe.gov/File\%20Library/research/coal/energy\%20systems/fuel\% 20cells/FCHandbook7.pdf.

[15] Tsipis, Ekaterina, and Vladislav Kharton. "Electrode Materials and Reaction Mechanisms in Solid Oxide Fuel Cells: A Brief Review." Journal of Solid State Electrochemistry 12, no. 11 (November 2008): 1367-91. doi:10.1007/s10008008-0611-6.

[16] Zhu, W.Z, and S.C Deevi. "A Review on the Status of Anode Materials for Solid Oxide Fuel Cells." Materials Science and Engineering: A 362, no. 1-2 (December 2003): 228-39. doi:10.1016/S0921-5093(03)00620-8. 
[17] Sun, Chunwen, and Ulrich Stimming. "Recent Anode Advances in Solid Oxide Fuel Cells." Journal of Power Sources 171, no. 2 (September 2007): 247-60. doi:10.1016/j.jpowsour.2007.06.086.

[18] Fergus, Jeffrey W. "Electrolytes for Solid Oxide Fuel Cells." Journal of Power Sources 162, no. 1 (November 2006): 30-40. doi:10.1016/j.jpowsour.2006.06.062.

[19] Huijsmans, J. "Ceramics in Solid Oxide Fuel Cells." Current Opinion in Solid State and Materials Science 5, no. 4 (August 2001): 317-23. doi:10.1016/S13590286(00)00034-6.

[20] Kharton, V, F Marques, and A Atkinson. "Transport Properties of Solid Oxide Electrolyte Ceramics: A Brief Review." Solid State lonics 174, no. 1-4 (October 29, 2004): 135-49. doi:10.1016/j.ssi.2004.06.015.

[21] Nomura, K. "Aging and Raman Scattering Study of Scandia and Yttria Doped Zirconia." Solid State lonics 132, no. 3-4 (July 2, 2000): 235-39. doi:10.1016/S0167-2738(00)00648-2.

[22] Vohs, John M., and Raymond J. Gorte. "High-Performance SOFC Cathodes Prepared by Infiltration." Advanced Materials 21, no. 9 (March 6, 2009): 943-56. doi:10.1002/adma.200802428.

[23] Perry Murray, E. "(La,Sr)MnO3-(Ce,Gd)O2-x Composite Cathodes for Solid Oxide Fuel Cells." Solid State lonics 143, no. 3-4 (July 2, 2001): 265-73. doi:10.1016/S0167-2738(01)00871-2.

[24] "Gasification | Department of Energy." Accessed October 20, 2015. http://energy.gov/fe/science-innovation/clean-coal-research/gasification.

[25] "Hydrogen Resources | Department of Energy." Accessed October 21, 2015. http://energy.gov/eere/fuelcells/hydrogen-resources. 
[26] Tonkovich, Anna Lee Y., Bin Yang, Steven T. Perry, Sean P. Fitzgerald, and Yong Wang. "From Seconds to Milliseconds to Microseconds through Tailored Microchannel Reactor Design of a Steam Methane Reformer." Catalysis Today 120, no. 1 (January 2007): 21-29. doi:10.1016/j.cattod.2006.07.022.

[27] Solomon, P.R., T.H. Fletcher, and R.J. Pugmire. "Progress in Coal Pyrolysis." Fuel 72, no. 5 (May 1993): 587-97. doi:10.1016/0016-2361(93)90570-R.

[28] Molina, Alejandro, and Fanor Mondragón. "Reactivity of Coal Gasification with Steam and CO2." Fuel 77, no. 15 (December 1998): 1831-39. doi:10.1016/S0016-2361(98)00123-9.

[29] Cayan, Fatma Nihan, Mingjia Zhi, Suryanarayana Raju Pakalapati, Ismail Celik, Nianqiang Wu, and Randall Gemmen. "Effects of Coal Syngas Impurities on Anodes of Solid Oxide Fuel Cells." Journal of Power Sources 185, no. 2 (December 2008): 595-602. doi:10.1016/j.jpowsour.2008.06.058.

[30] Krishnan, Gopala. "Effect of Coal Contaminants on Solid Oxide Fuel System Performance and Service Life." Accessed October 21, 2015. http://www.osti.gov/scitech/servlets/purl/957507.

[31] Trembly, Jason P., Andres I. Marquez, Ted R. Ohrn, and David J. Bayless. "Effects of Coal Syngas and H2S on the Performance of Solid Oxide Fuel Cells: SingleCell Tests." Journal of Power Sources 158, no. 1 (July 2006): 263-73. doi:10.1016/j.jpowsour.2005.09.055.

[32] Xu, Chunchuan, John W. Zondlo, Harry O. Finklea, Oktay Demircan, Mingyang Gong, and XingBo Liu. "The Effect of Phosphine in Syngas on Ni-YSZ AnodeSupported Solid Oxide Fuel Cells." Journal of Power Sources 193, no. 2 (September 2009): 739-46. doi:10.1016/j.jpowsour.2009.04.044.

[33] Chen, Yun, Song Chen, Gregory Hackett, Harry Finklea, John Zondlo, Ismail Celik, Xueyan Song, and Kirk Gerdes. "Microstructure Degradation of YSZ in Ni/YSZ Anodes of SOFC Operated in Phosphine-Containing Fuels." Solid State lonics 234 (March 2013): 25-32. doi:10.1016/j.ssi.2012.12.019. 
[34] Li, T. S., C. Gao, M. Xu, B. Li, M. Wu, and W. G. Wang. "Effects of $\mathrm{PH}_{3}$ and $\mathrm{CH}_{3}$ Cl Contaminants on the Performance of Solid Oxide Fuel Cells." Fuel Cells 14, no. 6 (December 2014): 999-1005. doi:10.1002/fuce.201300248.

[35] Marina, O.A., C.A. Coyle, E.C. Thomsen, D.J. Edwards, G.W. Coffey, and L.R. Pederson. "Degradation Mechanisms of SOFC Anodes in Coal Gas Containing Phosphorus." Solid State Ionics 181, no. 8-10 (March 29, 2010): 430-40. doi:10.1016/j.ssi.2010.01.018.

[36] Kakac, S, A Pramuanjaroenkij, and X Zhou. "A Review of Numerical Modeling of Solid Oxide Fuel Cells." International Journal of Hydrogen Energy 32, no. 7 (May 2007): 761-86. doi:10.1016/j.ijhydene.2006.11.028.

[37] Hajimolana, S. Ahmad, M. Azlan Hussain, W.M. Ashri Wan Daud, M. Soroush, and A. Shamiri. "Mathematical Modeling of Solid Oxide Fuel Cells: A Review." Renewable and Sustainable Energy Reviews 15, no. 4 (May 2011): 1893-1917. doi:10.1016/j.rser.2010.12.011.

[38] Grew, Kyle N., and Wilson K.S. Chiu. "A Review of Modeling and Simulation Techniques across the Length Scales for the Solid Oxide Fuel Cell." Journal of Power Sources 199 (February 2012): 1-13. doi:10.1016/j.jpowsour.2011.10.010.

[39] Sezer, H., T. Yang, and B. Celik. "Electrochemical Analysis of Phosphine Induced Anode Degradation in a Planer SOFC: A Numerical Study." presented at the Electrochemical Society, Glasglow, July 26, 2015.

[40] Gansor, Phil, Chunchuan Xu, Katarzyna Sabolsky, John W. Zondlo, and Edward M. Sabolsky. "Phosphine Impurity Tolerance of Sr2MgMoO6- $\delta$ Composite SOFC Anodes." Journal of Power Sources 198 (January 2012): 7-13. doi:10.1016/j.jpowsour.2011.09.069.

[41] Guan, Wanbing, and Wei Guo Wang. "Electrochemical Performance of Planar Solid Oxide Fuel Cell (SOFC) Stacks: From Repeat Unit to Module." Energy Technology 2, no. 8 (August 2014): 692-97. doi:10.1002/ente.201402015. 
[42] "Dissemination of IT for the Promotion of Materials Science (DoITPoMS) - TLP Library Fuel Cells." University of Cambridge. Accessed August 4, 2015. http://www.doitpoms.ac.uk/tiplib/fuel-cells/printall.php.

[43] “Haynes 242 Alloy - Haynes International.” Accessed November 4, 2015. http://www.haynesintl.com/pdf/h3079.pdf.

[44] "INCONEL Alloy 601 - Special Metals Corporation." Accessed November 4, 2015. http://www.specialmetals.com/assets/documents/alloys/inconel/inconel-alloy601.pdf.

[45] Wu, Junwei, Christopher D. Johnson, Randall S. Gemmen, and Xingbo Liu. "The Performance of Solid Oxide Fuel Cells with Mn-Co Electroplated Interconnect as Cathode Current Collector." Journal of Power Sources 189, no. 2 (April 2009): 1106-13. doi:10.1016/j.jpowsour.2008.12.079.

[46] Huang, Kevin. "Fuel Utilization and Fuel Sensitivity of Solid Oxide Fuel Cells." Journal of Power Sources 196, no. 5 (March 2011): 2763-67. doi:10.1016/j.jpowsour.2010.10.077.

[47] "Technical Note TN-106 A Guideline for PID Instriment Response - Technical-Note106_A-Guideline-for-Pid-Instrument-Response.pdf." Accessed November 11, 2015. http://www.raesystems.com/sites/default/files/content/resources/TechnicalNote-106_A-Guideline-for-Pid-Instrument-Response.pdf.

[48] "Microsoft Word - Scribner Tutorial EIS for Fuel Cell Research v5.doc - Scribner Associates - Electrochemical Impedance Spectroscopy for Fuel Cell Research.pdf." Accessed July 21, 2015. http://www.scribner.com/files/techpapers/Scribner\%20Associates\%20\%20Electrochemical\%20Impedance\%20Spectroscopy\%20for\%20Fuel\%20Cell\% 20Research.pdf.

[49] "Basics of Electrochemical Impedance Spectroscopy." Accessed July 21, 2015. https://www.gamry.com/application-notes/EIS/basics-of-electrochemicalimpedance-spectroscopy/. 
[50] "NEXTCELL-7." Accessed May 5, 2015. https://www.fuelcellmaterials.com/site/sofccomponents/cells-a-

substrates?page=shop.product details\&flypage=vmj naru.tpl\&product id=73\&ca tegory id=7.

[51] Adler, Stuart B. "Factors Governing Oxygen Reduction in Solid Oxide Fuel Cell Cathodes †." Chemical Reviews 104, no. 10 (October 2004): 4791-4844. doi:10.1021/cr020724o.

[52] Alman, D.E., C.D. Johnson, W.K. Collins, and P.D. Jablonski. "The Effect of Cerium Surface Treated Ferritic Stainless Steel Current Collectors on the Performance of Solid Oxide Fuel Cells (SOFC)." Journal of Power Sources 168, no. 2 (June 2007): 351-55. doi:10.1016/j.jpowsour.2007.03.035.

[53] Sun, Chunwen, Rob Hui, and Justin Roller. "Cathode Materials for Solid Oxide Fuel Cells: A Review." Journal of Solid State Electrochemistry 14, no. 7 (July 2010): 1125-44. doi:10.1007/s10008-009-0932-0.

[54] Lee, S., N. Miller, and K. Gerdes. "Long-Term Stability of SOFC Composite Cathode Activated by Electrocatalyst Infiltration." Journal of the Electrochemical Society 159, no. 7 (January 1, 2012): F301-8. doi:10.1149/2.067207jes.

[55] "MultiRae IR Multi-Gas Monitor PGM-54 Operation and Maintenance Manual." RAE Systems Inc., December 2001.

[56] Martinez, Andrew, Kirk Gerdes, Randall Gemmen, and James Poston.

"Thermodynamic Analysis of Interactions between Ni-Based Solid Oxide Fuel Cells (SOFC) Anodes and Trace Species in a Survey of Coal Syngas." Journal of Power Sources 195, no. 16 (August 2010): 5206-12. doi:10.1016/j.jpowsour.2010.03.046.

[57] Zhang, Wei. "Analysis of Gas Phase Composition in Fuel and Exhaust Gas in Solid Oxide Fuel Cells." West Virginia University, 2014. http://hdl.handle.net/10450/16104.

[58] Kishimoto, H., K. Yamaji, M.E. Brito, T. Horita, and H. Yokokawa. "Generalized Ellingham Diagrams for Utilization in Solid Oxide Fuel Cells." Journal of Mining and Metallurgy, Section B: Metallurgy 44, no. 1 (2008): 39-48. doi:10.2298/JMMB0801039K. 